RAFAEL VINÍCIUS BASSO

\title{
ESTUDO TENSÃO-DEFORMAÇÃO DE UM ENROCAMENTO VISANDO BARRAGENS DE ENROCAMENTO COM FACE DE CONCRETO
}

Dissertação apresentada à Escola Politécnica da Universidade de São Paulo para obtenção do título de Mestre em Engenharia 
RAFAEL VINÍCIUS BASSO

\title{
ESTUDO TENSÃO-DEFORMAÇÃO DE UM ENROCAMENTO VISANDO BARRAGENS DE ENROCAMENTO COM FACE DE CONCRETO
}

\author{
Dissertação apresentada à Escola Politécnica da \\ Universidade de São Paulo para obtenção do \\ título de Mestre em Engenharia \\ Área de Concentração: Engenharia Geotécnica \\ Orientador: Prof. Dr. Paulo Teixeira da Cruz
}

São Paulo 


\section{DEDICATÓRIA}

Dedico aos meus pais Edemar (in memorian) e Dorli pelo amor, dedicação, confiança e compreensão em todos os momentos da minha vida. A vocês minha eterna gratidão. 


\section{AGRADECIMENTOS}

Aos membros da minha família que sempre foram exemplos de coragem, amor, determinação, honestidade e perseverança, principalmente aos meus pais, por terem me apoiado incondicionalmente e serem grandes responsáveis pela formação do meu caráter.

Ao Professor Dr. Paulo Teixeira da Cruz, mais que um professor, um amigo com quem pude interagir e adquirir experiência, amadurecimento e devoção. Pela orientação, ensinamentos e incentivo durante todo o período de realização do trabalho.

Ao corpo docente da pós-graduação da Escola Politécnica da USP, em especial aos professores Carlos de Souza Pinto e Marcos Massao Futai pelos conselhos e sugestões durante o desenvolvimento da pesquisa.

Aos membros das bancas avaliadoras, por aceitarem o convite para participar.

À CAPES e à Pró-Reitoria da USP pelos auxílios concedidos, os quais foram essenciais para a concretização deste trabalho.

Ao Laboratório de Engenharia Civil de Furnas Centrais Elétricas S.A., Eng ${ }^{0}$ Sérgio Fleury e demais funcionários pela realização dos ensaios.

Aos docentes do curso de Engenharia Civil da Universidade Estadual de Maringá, que contribuíram com conhecimentos para minha formação.

Aos professores Antônio Belincanta e Roberto Lopes Ferraz por despertarem o interesse geotécnico e incentivarem o prosseguimento acadêmico-científico.

À Raquel Suzuki pelo amor, carinho e paciência nos períodos de ausência.

Aos colegas da USP Carlos, Fernando, Márcio, Gabriel, José Henrique, Arlindo, Luciano, Ticiana e Marcos pelo companheirismo e amizades conquistadas.

Aos amigos Ricardo, Cristiano, Cecília, Thiago, Bruna, Rodrigo, Eduardo e Fábio pelo apoio e incentivo durante essa fase da vida.

E a todas as outras pessoas que direta ou indiretamente colaboraram com o sucesso deste trabalho.

A todos, os meus sinceros agradecimentos. 


\section{SUMÁRIO}

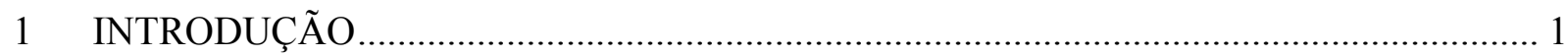

2 BARRAGEM DE ENROCAMENTO COM FACE DE CONCRETO (BEFC):

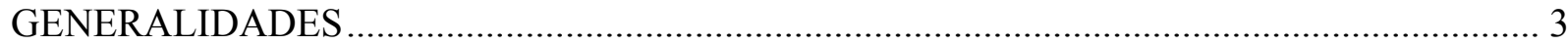

2.1 Definição de barragens de enrocamento.............................................................................. 3

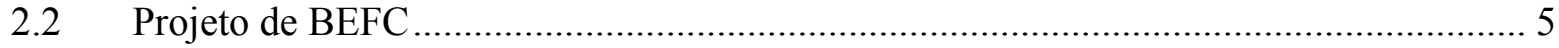

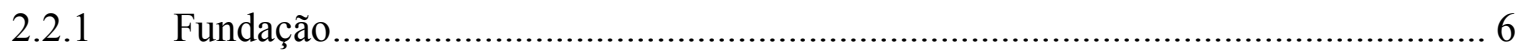

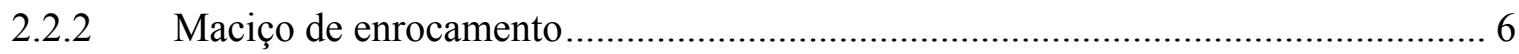

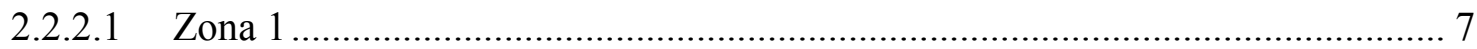

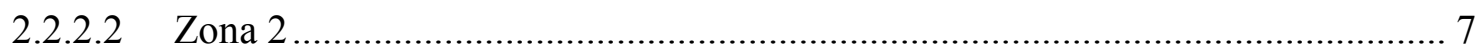

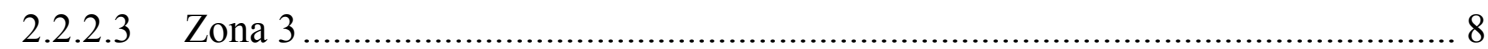

2.2.3 Granulometria, qualidade do enrocamento e adição de água ................................. 9

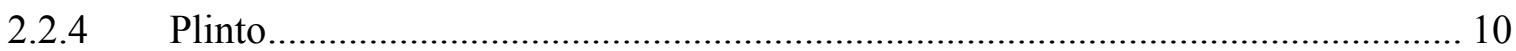

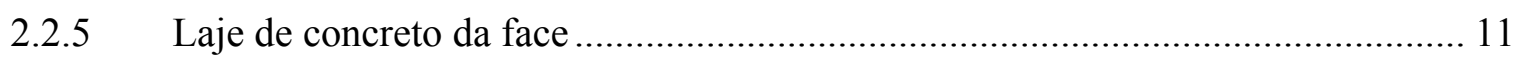

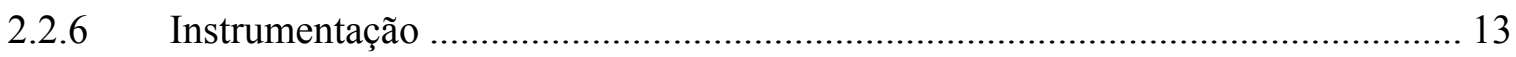

2.3 Pratica Usual de Previsão do Comportamento de Deformação do Maciço.................... 13

2.3.1 Módulo de deformabilidade durante a construção ............................................... 13

2.3.2 Módulo de deformabilidade durante o enchimento do reservatório...................... 15

2.4 Casos históricos, referências e comentários sobre o comportamento de deformação de

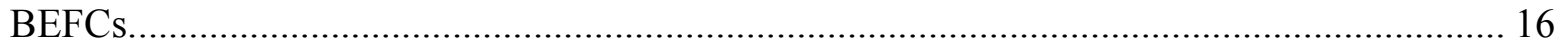

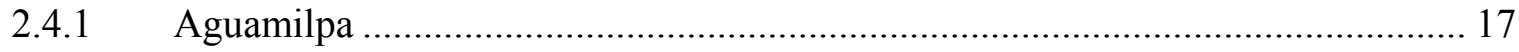

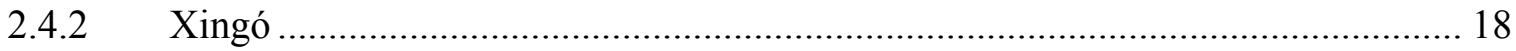

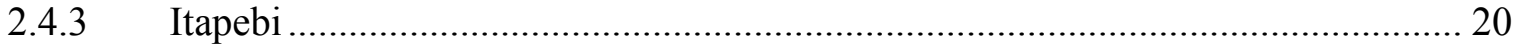

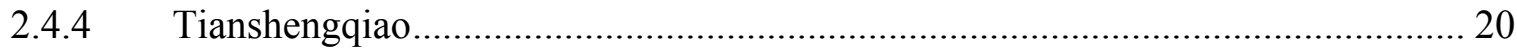

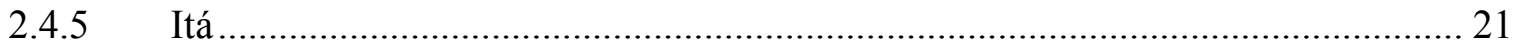

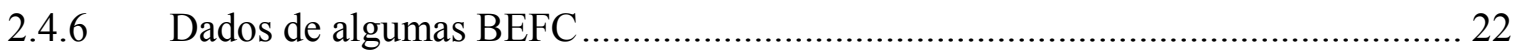

3 DEFORMABILIDADE DE ENROCAMENTOS ….......................................................... 23

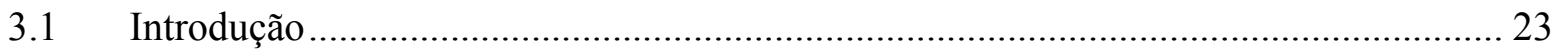

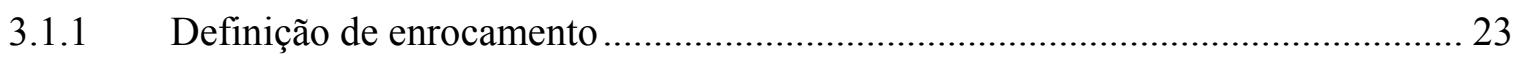

3.1.2 A importância de se estudar a deformação .......................................................... 24 
3.1.3 Dificuldade de análise, busca de parâmetros e representatividade........................ 25

3.2 Investigações de laboratório em amostras de enrocamento ........................................ 26

3.2.1 Inter-relação e representatividade das condições de campo e laboratório.............. 26

3.2.2 Comportamento fenomenológico .......................................................................... 28

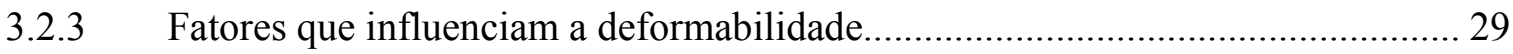

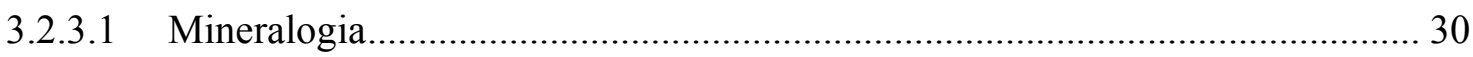

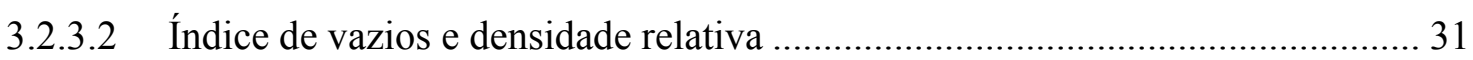

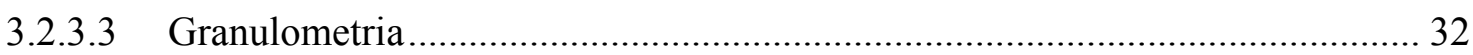

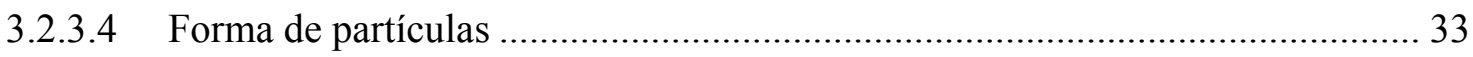

3.2.3.5 Dimensão e resistência dos grãos ...................................................................... 33

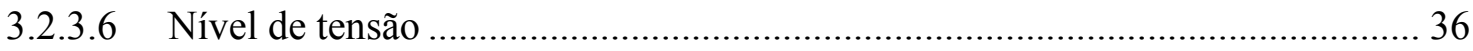

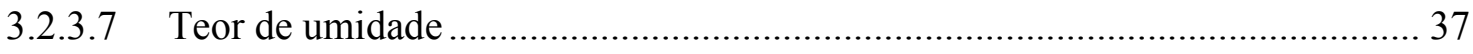

3.3 Comportamento do maciço de enrocamento em BEFC …............................................ 37

3.3.1 Rotação do plano principal maior.......................................................................... 41

4 LEIS CONSTITUTIVAS E PARÂMETROS DE ANÁLISE ….......................................... 43

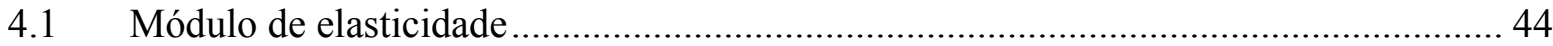

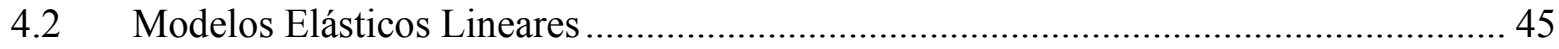

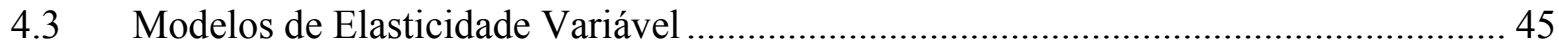

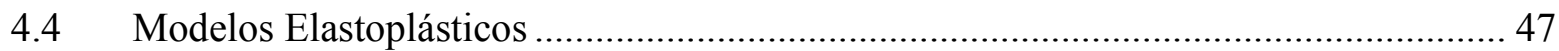

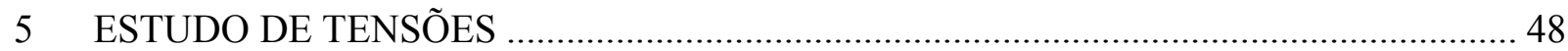

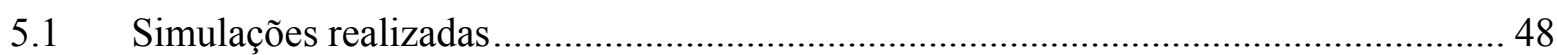

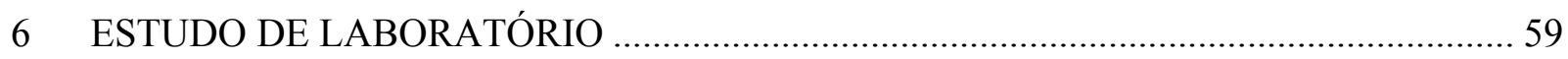

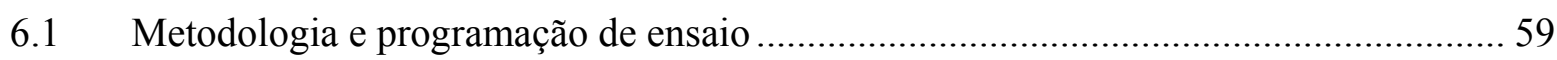

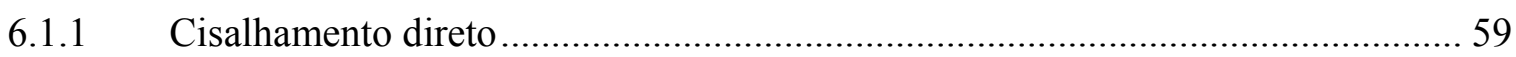

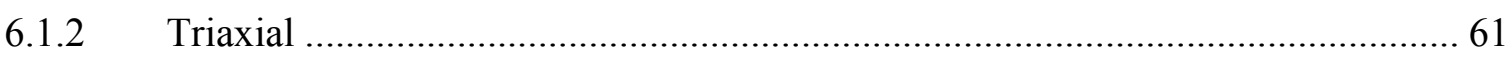

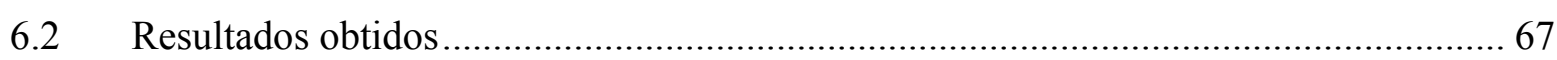

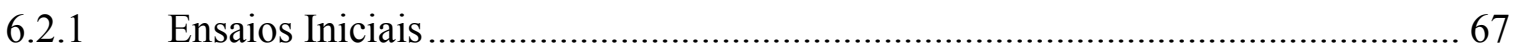

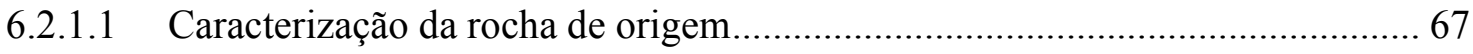

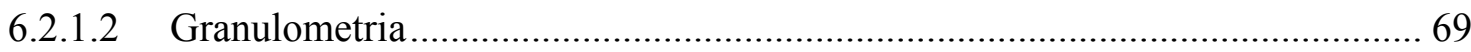

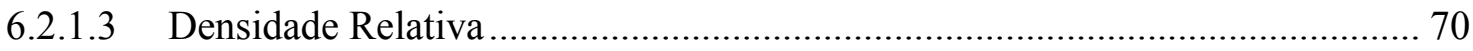

6.2.2 Ensaio de Cisalhamento Direto ............................................................................... 71 


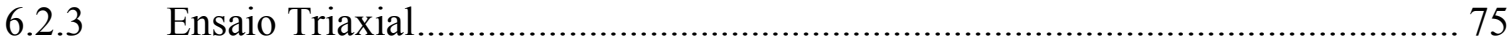

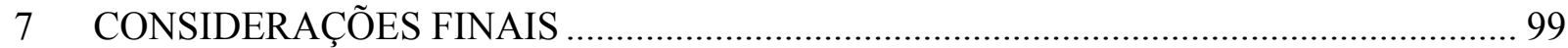

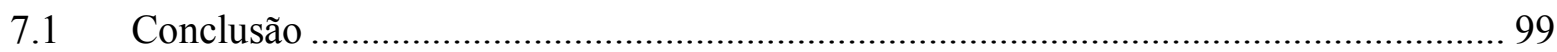

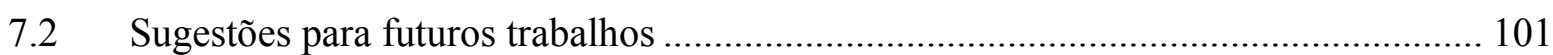




\section{LISTA DE FIGURAS}

Figura 1. Barragem de enrocamento com face de concreto ................................................... 4

Figura 2. Barragem de enrocamento com núcleo central......................................................... 4

Figura 3. Zoneamento típico de BEFC, Cooke (1999)......................................................... 7

Figura 4. Método de cálculo do módulo de enchimento......................................................... 15

Figura 5. Barragem de Aguamilpa: seção do zoneamento do maciço e deflexão da laje, Marques Filho \& Pinto (2004). 18

Figura 6. Barragem de Xingo: deformada da laje no período de operação (pós-construtivo), Penman \& Rocha Filho (2001).

Figura 7. Barragem de Itapebi: seção do zoneamento do maciço e deflexão da laje na ombreira direita, Marques Filho \& Pinto (2004).

Figura 8. Barragem de Itá: seção do zoneamento do maciço e deflexão da laje, Oliveira (2005).

Figura 9. Faixa granulométrica dos chamados enrocamentos, Neves (2002).

Figura 10. Método de modelagem da curva granulométrica de campo, Veiga Pinto (1982). 27

Figura 11. Comportamento de deformação unidirecional para amostras com mesmo índice de vazios, porem diferentes granulometria e densidade relativa, Santos et al. (2005)...................... 32

Figura 12. Distribuição normal das forças de contato, Marsal (1969)................................... 35

Figura 13. Deformação volumétrica na ruptura para diferentes níveis de tensões em granulometrias distintas de basalto, Marachi et al. (1969). 36

Figura 14. Abaulamento da seção do maciço ao final de construção e conseqüente deflexão da face de montante com o enchimento do reservatório, Mori (1999).

Figura 15. Esquema ilustrativo do processo de carregamento, para a fase de enchimento do reservatório, Mori (1999).

Figura 16. Fenômeno de rotação das tensões principais, na região de montante, devido ao enchimento do reservatório.

Figura 17. Obtenção de parâmetros de compressibilidade através de ensaios laboratoriais, Lambe (1969).

Figura 18. Métodos de obtenção de módulos de deformabilidade. 46 
Figura 19. Malha de elementos finitos utilizada para simulação na condição de zoneamento de diferentes módulos

Figura 20. Esquema representativo dos pontos analisados e resultados dos vetores de tensões principais maiores $\sigma_{l}$ obtidos na simulação numérica 50

Figura 21. Trajetória de tensões para os pontos da linha " $m$ " .............................................. 53

Figura 22. Trajetória de tensões para os pontos da linha " $n$ ". ................................................ 54

Figura 23. Trajetória de tensões para os pontos da linha " $o$ " ................................................ 55

Figura 24. Relação entre as tensões normais aos planos perpendiculares $\sigma_{\text {perp. }}$ e paralelos $\sigma_{\text {paral }}$ a face para os pontos analisados na simulação numérica.

Figura 25. Equipamento de cisalhamento direto (prensa SBEL), Furnas Centrais Elétricas S.A. 60

Figura 26. Equipamento tri-triaxial, Furnas Centrais Elétricas S.A. ...................................... 62

Figura 27. Trajetória de tensões para ensaios de carregamento transversal. .......................... 66

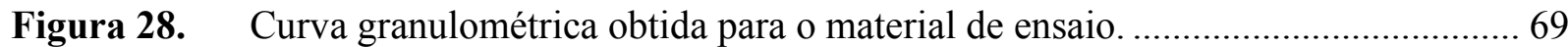

Figura 29. Curvas de tensão-deformação para ensaios de cisalhamento direto com diferentes tensões normais. 72

Figura 30. Envoltória de resistência do material ensaiado..................................................... 74

Figura 31. Variação do ângulo de atrito com a tensão normal para o material ensaiado. ...... 74 Figura 32. Relação tensão-deformação do ensaio triaxial convencional para tensão confinante de $100 \mathrm{kPa}$. 76

Figura 33. Relação tensão-deformação do ensaio triaxial convencional para tensão confinante de $500 \mathrm{kPa}$.

Figura 34. Relação tensão-deformação do ensaio triaxial convencional para tensão confinante de $1000 \mathrm{kPa}$.

Figura 35. Circulo de Mohr para as tensões desviadoras aplicadas nos ensaios convencionais e envoltória de resistência do material obtida no ensaio de cisalhamento direto. 80

Figura 36. Transformada da tensão desviadora para interpretação de parâmetros através do modelo hiperbólico. 81

Figura 37. Módulos de deformabilidade axiais referentes aos ensaios triaxiais convencionais. 
Figura 38. Variação dos módulos axiais iniciais e médios com a tensão confinante referente aos ensaios convencionais.

Figura 39. Relação tensão-deformação do ensaio triaxial de descarregamento para tensão confinante de $200 \mathrm{kPa}$.

Figura 40. Relação tensão-deformação do ensaio triaxial de descarregamento para tensão confinante de $700 \mathrm{kPa}$.

Figura 41. Módulos de deformabilidade axiais referentes ao ensaio triaxial de descarregamento para tensão confinante de $200 \mathrm{kPa}$.

Figura 42. Módulos de deformabilidade axiais referentes ao ensaio triaxial de descarregamento para tensão confinante de $700 \mathrm{kPa}$.

Figura 43. Relação tensão-deformação referente ao ensaio isotrópico.

Figura 44. Variação do módulo de deformabilidade volumétrico com a tensão octaédrica referente ao ensaio isotrópico. 88

Figura 45. Trajetórias de tensões executadas nos ensaios triaxiais transversais. 90

Figura 46. Relação tensão-deformação volumétrica referente ao ensaio triaxial transversal para tensão confinante inicial de $200 \mathrm{kPa}$.

Figura 47. Relação tensão-deformação axial referente ao ensaio triaxial transversal para tensão confinante inicial de $200 \mathrm{kPa}$.

Figura 48. Relação tensão-deformação lateral referente ao ensaio triaxial transversal para tensão confinante inicial de $200 \mathrm{kPa}$.

Figura 49. Relação tensão-deformação volumétrica referente ao ensaio triaxial transversal para tensão confinante inicial de $500 \mathrm{kPa}$.

Figura 50. Relação tensão-deformação axial referente ao ensaio triaxial transversal para tensão confinante inicial de $500 \mathrm{kPa}$

Figura 51. Relação tensão-deformação lateral referente ao ensaio triaxial transversal para tensão confinante inicial de $500 \mathrm{kPa}$

Figura 52. Relação tensão-deformação volumétrica referente ao ensaio triaxial transversal para tensão confinante inicial de $1000 \mathrm{kPa}$

Figura 53. Relação tensão-deformação axial referente ao ensaio triaxial transversal para tensão confinante inicial de $1000 \mathrm{kPa}$ 
Figura 54. Relação tensão-deformação lateral referente ao ensaio triaxial transversal para tensão confinante inicial de $1000 \mathrm{kPa}$

Figura 55. Módulos de deformabilidade volumétrico referentes ao ensaio triaxial transversal para tensão confinante inicial de $200 \mathrm{kPa}$

Figura 56. Módulos de deformabilidade volumétrico referentes ao ensaio triaxial transversal para tensão confinante inicial de $500 \mathrm{kPa}$

Figura 57. Módulos de deformabilidade volumétrico referentes ao ensaio triaxial transversal para tensão confinante inicial de $1000 \mathrm{kPa}$

Figura 58. Trasformada da curva tensão-deformação de ensaio triaxial ( $\varnothing=12 ")$ para o enroncamento do basalto São Francisco, Marachi (1969) 108

Figura 59. Variação do ângulo de atrito interno com a tensão confinante para o enroncamento do basalto de São Francisco, Marachi (1969) 110

Figura 60. Gráfico de descarga e recarga da tensão desviadora. 111 


\section{LISTA DE TABELAS}

Tabela 1. Alguns parâmetros de construção e comportamento de BEFCs, Pinto \& Marques Filho (1998).

Tabela 2. Resultados das tensões cisalhantes, tensões principais maiores e menores, tensões normais aos planos paralelos e perpendiculares a face e tensões verticais e horizontais, em $\mathrm{kPa} e$ ângulos de atuação em relação a vertical, em ${ }^{\circ}$, obtidos da simulação numérica para cada ponto analisado. 52

Tabela 3. Programação de cargas para os ensaios tri-triaxiais. 65

Tabela 4. Propriedades mecânicas da rocha e as características físicas e geométricas dos fragmentos. 68

Tabela 5. Resultados do ensaio de compactação (densidade relativa). 71 


\section{LISTA DE ABREVIATURAS, SIGLAS E SÍMBOLOS}

ASTM - American Society for Testing Materials

ABNT - Associação Brasileira de Normas Técnicas

$A$ - área

BEFC - Barragem de Enrocamento com Face de Concreto

$\mathrm{B}_{\mathrm{g}}$ - indice de quebra

$\mathrm{B}_{\mathrm{t}}-$ Módulo de deformabilidade volumétrico tangente

CFRD - Concrete Face Rockfill Dam

$\mathrm{C}_{\mathrm{f}}$ - coeficiente de forma

$\mathrm{C}_{\mathrm{u}}$ - coeficiente de uniformidade

$D$ - distância transversal

$\mathrm{D}_{\mathrm{a}}$ - diâmetro da amostra

$\mathrm{D}_{\text {máx }}$ - diâmetro máximo dos grãos

$\mathrm{D}_{\mathrm{r}}$ - densidade relativa

$\mathrm{E}_{\text {const. }}$ - Módulo de deformabilidade na fase de construção da barragem

$\mathrm{E}_{\mathrm{DR}}$ - Módulo de deformabilidade para o descarregamento e recarregamento

$\mathrm{E}_{\text {ench. }}$ - Módulo de deformabilidade perpendicular ao parâmetro de montante durante a fase de enchimento do reservatório

$\mathrm{E}_{\mathrm{i}}-$ Módulo de deformabilidade inicial

$\mathrm{E}_{\mathrm{mob}}$ - Módulo de deformabilidade para tensões mobilizadas

$\mathrm{E}_{\mathrm{sec}}$ - Módulo de deformabilidade obtidos através de retas secantes

$\mathrm{E}_{\text {sec.vol. }}$ - Módulo de deformabilidade secante para deformações volumétricas

$\mathrm{E}_{\mathrm{t}}$ - Módulo de deformabilidade obtidos através de retas tangentes

$\mathrm{E}_{\mathrm{T}}$ ou $\mathrm{E}_{\text {trans. }}-$ Módulo de deformabilidade transversal (idem $\mathrm{E}_{\text {ench. }}$ )

$\mathrm{E}_{\mathrm{v}}-$ Módulo de deformabilidade vertical

$\mathrm{f}_{\mathrm{ck}}-$ resistência característica do concreto

GPa - Giga Pascal

$H$ - altura, espessura de camada

$\mathrm{H}_{\mathrm{w}}$ - altura da coluna d'água

$\mathrm{kN} / \mathrm{m}^{3}$ - kilo Neuwton por metro cúbico 
$\mathrm{kPa}$ - kilo Pascal

$L$ - comprimento

1/s - litros por segundo

LVDT - Linear Variable Differential Transformers

$\mathrm{m}-$ metros

$m c a$ - metro de coluna d'água

MEF - Método de Elementos Finitos

$\mathrm{mm}$ - milímetros

$\mathrm{MPa}$ - Mega Pascal

NBR - Norma Brasileira Regulamentadora

$P$ - peso médio do grão

$P_{a}-$ força de contato entre partículas

PVC - Poly Vinyl Chloride

$\mathrm{R}_{\mathrm{f}}$ - coeficiente de ruptura

$V$ - volume

$\Delta \mathrm{H}-$ recalque

$\Delta \mathrm{D}$ - diferença de diâmetro

$\Delta \mathrm{V}$ - variação volumétrica

$\gamma_{\text {enroc. }}-$ massa específica do enrocamento

$\gamma_{\mathrm{w}}$ - massa específica da água

$\gamma_{\mathrm{dg}}-$ massa específica da rocha

$\gamma_{\text {nat. }}$ - massa específica natural

$\gamma_{\text {máx. }}-$ massa específica máxima

$\gamma_{\text {mín. }}$ - massa específica mínima

$\delta$ - deslocamento normal a face de montante

$\sigma-$ tensão

$\sigma_{1}-$ tensão principal maior

$\sigma_{3}-$ tensão principal menor

$\sigma_{\mathrm{a}}-$ tensão axial

$\sigma_{\mathrm{c}}-$ tensão confinante 
$\sigma_{\text {oct }}-$ tensão octaédrica

$\sigma_{\text {paral. }}$ - tensão normal ao plano paralelo a face de montante

$\sigma_{\text {perp. }}$ - tensão normal ao plano perpendicular a face de montante

$\sigma_{\mathrm{h}}-$ tensão horizontal

$\sigma_{\mathrm{v}}-$ tensão vertical

$\phi$ - diâmetro do grão

$\varnothing_{\text {max. }}$ - diâmetro máximo

$\varphi$ - ângulo de atrito

$\tau$ - tensão cisalhante

$\varepsilon$ - deformação específica

$\varepsilon_{\mathrm{a}}-$ deformação específica axial

$\varepsilon_{\mathrm{c}}$ - deformação específica de confinamento

$\varepsilon_{\mathrm{v}}$ - deformação específica volumétrica

deformação específica axial

$v$ - coeficiente de poisson

$\beta$ - ângulo de rotação em relação a vertical

“-polegada 


\section{RESUMO}

O crescimento do número de Barragens de Enrocamento com Face de Concreto (BEFC) no Brasil e no mundo e os problemas relacionados com a movimentação da face motivaram o desenvolvimento deste estudo sobre o comportamento mecânico do enrocamento. Geralmente, as previsões dos movimentos diferenciais do maciço são feitas com base nas características de deformabilidade do material. Este trabalho apresenta um estudo de tensão-deformação de enrocamento baseado em análise numérica de uma seção de barragem de grande altura, com o objetivo de definir o estado e as trajetórias de tensões que influenciam os valores dos parâmetros de deformabilidade. Baseado nas condições de carregamento previstas para o maciço de enrocamento, foi desenvolvida a programação e as metodologias dos ensaios laboratoriais. A partir dos resultados destes ensaios foi possível estimar os parâmetros de deformabilidade do enrocamento a serem utilizados em estudos tensão-deformação.

Palavras-chave: Aterros, Barragem de Enrocamento com Face de Concreto, Deformabilidade. 


\begin{abstract}
The important growth in the number of Concrete Face Rockfill Dams (CFRD's) in Brazil and in the World, and the reported problems related to movements of the concrete slab, motivated the present study of mechanical behavior of the rockfill. In general, predictions of the differential movements within the rockfill mass are based on the deformation properties of the rockfill materials. This work presents a stress-strain study of the rockfill mass, based on a numerical analysis of a high dam cross section, aiming to define the stress state and stress paths that influence the deformability parameters. Based on the loading condition estimated for the rockfill mass, the program and the methodology for the laboratorial tests was set. From these test results it was possible to estimate the deformability parameters of the rockfill to be used in stress-strain analysis.
\end{abstract}

Keywords: Embankments, Concrete Face Rockfill Dams, Deformability. 


\section{INTRODUÇÃO}

Durante as últimas décadas, vêm aumentando o número de Barragens de Enrocamento com Face de Concreto (BEFC) no Brasil e no mundo. As barragens desse tipo estão cada vez mais altas, esbeltas e evoluídas em relação ao projeto e ao sistema construtivo. Tem-se procurado reduzir custos e prazos, minimizar as infiltrações e, principalmente, diminuir e controlar os efeitos de deformabilidade do maciço de enrocamento. O comportamento mecânico do enrocamento é considerado pelos projetistas como um dos fatores de maior preocupação do projeto geotécnico em vista ao comportamento do sistema de vedação.

O maciço das BEFC, apesar de estável, mostra-se compressível na fase construtiva, na fase de enchimento do reservatório e no período de operação (pós-construtivo). As deformações, principalmente na fase do carregamento hidrostático (enchimento do reservatório), são responsáveis pelos movimentos diferenciais nas diversas zonas de enrocamento, resultando em deslocamentos significativos na face de montante e conseqüente formação de trincas e abertura das juntas na laje de concreto. Vazamentos significativos através do maciço têm ocorrido em recentes BEFC. Para evitar isso, a laje, juntamente com as estruturas de fundação (plinto), deverão ter características geométricas e estruturais capazes de realizarem movimentos sem que ocorra ruptura ou fissuramento em alguma região.

O objetivo deste trabalho é estudar o comportamento de "tensão-deformação" do material de enrocamento em virtude do elevado nível de tensão desenvolvido nas atuais e futuras obras de BEFC (algumas com altura superior a $200 \mathrm{~m}$ ). Procurou-se analisar numericamente as tensões que se desenvolvem no maciço de uma BEFC de grande altura para, posteriormente, simular, através de ensaios laboratoriais em menor escala, as condições de carregamento. Dessa forma, é possível fornecer parâmetros e informações do material granular ensaiado, para que sejam úteis em futuras análises de deformação do maciço para esse tipo de barragem.

Inicialmente, é apresentada uma revisão bibliográfica que foi dividida em três capítulos: $\mathrm{O}$ capítulo 2 apresenta a definição de barragens de enrocamento, alguns conceitos básicos adotados em projetos de BEFC e a prática usual de previsão do comportamento de deformação do maciço. 
No final desse capítulo, são apresentados casos de incidentes ocorridos em BEFCs. O capítulo 3 se refere exclusivamente à deformabilidade do enrocamento. Define-se o material e discute-se a importância de se estudar enrocamento, considerando as dificuldades de análise e representatividade. $\mathrm{Na}$ seqüência, são abordados fatores que interferem na deformabilidade do enrocamento. No final deste capítulo, são abordados aspectos ligados ao comportamento do maciço como um todo. O capítulo 4 apresenta os modelos constitutivos e os parâmetros usuais para avaliar o comportamento tensão-deformação do enrocamento, encerrando, então, a revisão bibliográfica.

O capítulo 5 se refere ao estudo de tensões. Uma análise numérica através do método de elementos finitos (MEF) disponibiliza resultados de tensões que se desenvolvem em diferentes pontos de uma seção de barragem hipotética de $200 \mathrm{~m}$ de altura, para as condições de carregamento próprio (fase construtiva do aterro) e carregamento hidrostático (fase de enchimento do reservatório). São avaliados o comportamento e as grandezas das tensões geradas, de forma a contemplar a programação dos ensaios laboratoriais pretendidos.

O capítulo 6 se refere ao estudo experimental realizado através de ensaios de laboratório. São apresentadas a programação e a metodologia dos ensaios de cisalhamento direto e triaxiais. Para que estes sejam realizados, foi necessário caracterizar a rocha de origem e definir uma granulometria e densidade relativa do material. No final, são apresentados os resultados de tensão-deformação dos ensaios, juntamente com as interpretações de módulos de deformabilidade para cada um deles. 


\section{BARRAGEM DE ENROCAMENTO COM FACE DE CONCRETO (BEFC): GENERALIDADES}

\subsection{Definição de barragens de enrocamento}

Define-se barragem de enrocamento como o maciço rochoso compactado em camadas que se constitui no corpo principal da estrutura. As barragens de enrocamento são geralmente construídas em locais onde as disponibilidades de solos apropriados para maciços impermeáveis são insuficientes para a construção do corpo da barragem ou onde é abundante a quantidade de rocha provinda de escavações obrigatórias.

Barragens de enrocamento necessitam sempre de um elemento de vedação, uma vez que o coeficiente de permeabilidade de um aterro de enrocamento é bastante alto. Esse elemento pode ser basicamente de dois tipos: interno e externo. O elemento de vedação define o tipo de barragem de enrocamento:

a) Barragem de enrocamento com vedação a montante.

Caracterizada por um aterro onde todo o corpo é constituído de enrocamento e o elemento impermeável situa-se na superfície do paramento de montante. O elemento vedante pode ser constituído de concreto, aço, material sintético, madeira ou betume.

As com face de concreto são as mais comuns entre as de face impermeabilizante, devido à tecnologia desenvolvida nas últimas décadas. Ela é constituída de uma laje de concreto na face de montante, contendo juntas verticais de construção entre os painéis. Na crista da barragem, sobre a extremidade superior da laje, existe um muro-parapeito de altura entre 3 a $5 \mathrm{~m}$ que permite economizar uma fatia do maciço de enrocamento. Uma estrutura de concreto chamada plinto constitui a base onde se apóiam as lajes na fundação. Entre essas duas estruturas há uma junta que se estende por todo o perímetro de montante. A Figura 1 apresenta a BEFC. 
b) Barragem de enrocamento com vedação central.

Nesse tipo de barragem, o elemento de vedação é do tipo interno (núcleo), geralmente de solo argiloso compactado (Figura 2). O núcleo pode ser central ou inclinado, assim como pode ser constituído de aço, concreto ou betume.

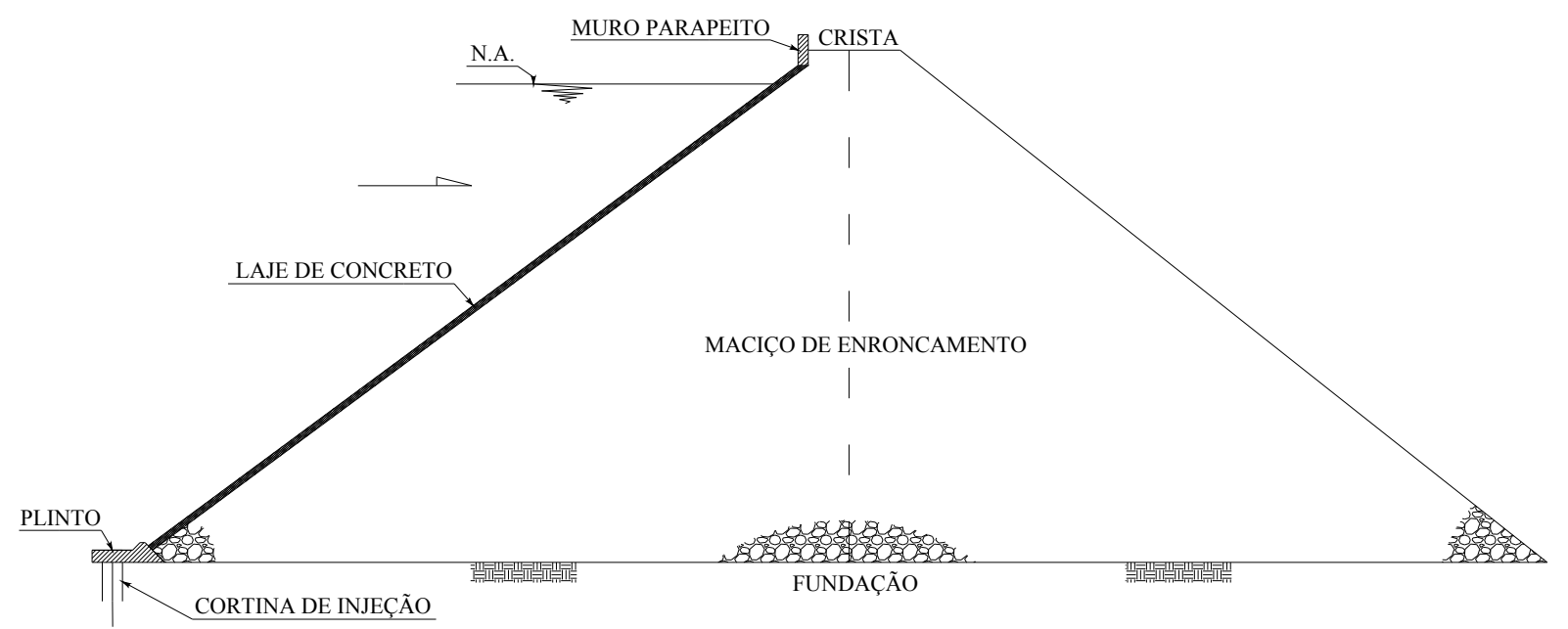

Figura 1. Barragem de enrocamento com face de concreto.

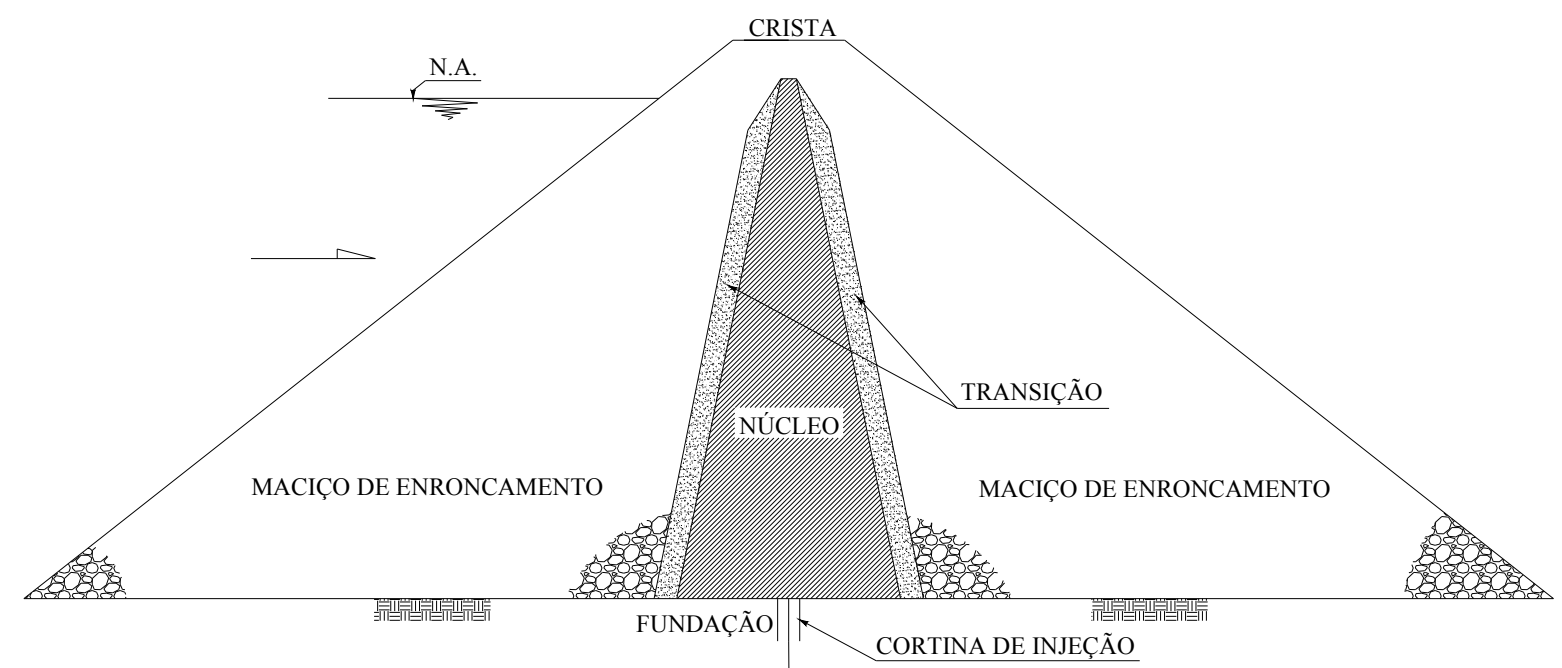

Figura 2. Barragem de enrocamento com núcleo central. 
As BEFC podem ser mais baratas que as de núcleo argiloso. Algumas vantagens são bem evidentes, segundo Saboya Júnior (1993):

- Maior dimensão das praças de compactação;

- Maior flexibilidade no transporte e no lançamento do material por meio de rampas internas;

- Maior espessura das camadas a serem compactadas;

- Inexistência de interferência do clima (período chuvoso) durante a compactação, propiciando uma maior confiabilidade nos prazos de construção;

- Possibilidade de obter durante a construção, uma proteção do maciço da barragem para cheias maiores que a ensecadeira, através da execução parcial da face de concreto;

- Tratamento das fundações localizado fora do corpo da barragem;

- Menores transições em comparação com as transições necessárias em barragens de núcleo argiloso.

Por outro lado, existe um adicional de custo nas barragens de enrocamento com face de concreto, ligadas a construção do plinto, da laje de concreto e do sistema de juntas. Outro fator que deve ser levado em conta é o conhecimento técnico já adquirido na construção de barragens de enrocamento com face de concreto, o que as coloca no mesmo nível de confiabilidade que as estruturas mais convencionais de barramentos.

\subsection{Projeto de BEFC}

As considerações abordadas neste item são baseadas nas publicações de Cooke \& Sherard (1985): “CONCRETE FACE ROCKFILL DAMS - Design, Construction and Performance". São abordados conceitos básicos de projeto e algumas técnicas construtivas. Mais detalhes e recomendações para projetos futuros são encontrados nos artigos Cooke (1999): "The Development of Today's CFRD Dam” e Materon \& Mori (2000): “Concrete Face Rockfill Dams Construction Features". 
Em BEFC, todo o maciço de enrocamento situa-se a jusante do plano de atuação do empuxo da água, fazendo com que toda a solicitação de enchimento seja distribuída pelo enrocamento e conseqüentemente pela fundação. A largura da base do maciço é maior que 2,6 vezes a sua altura, sendo que o coeficiente global de escorregamento (razão entre a resistência ao deslizamento na base e as solicitações horizontais) é cerca de 7,5.

\subsubsection{Fundação}

A fundação requer uma escavação e um tratamento menos rigoroso que as barragens de núcleo. O tratamento na região da fundação entre o plinto e o eixo da barragem deve ser tratado com mais critério. É recomendável remover todo o material altamente alterado e compressível e expor todos os pontos de rocha. Depósitos de cascalho aluvionar e saprolitos no leito do rio são comumente deixados, exceto em uma curta distância para jusante do plinto. Nas ombreiras, é aceitável que haja um abrandamento dos taludes negativos e faces verticais de alturas superiores a $2 \mathrm{~m}$.

\subsubsection{Maciço de enrocamento}

É útil usar designações padronizadas para o zoneamento do maciço que se aplicam às propriedades do material compactado, como se observa na Figura 3: 


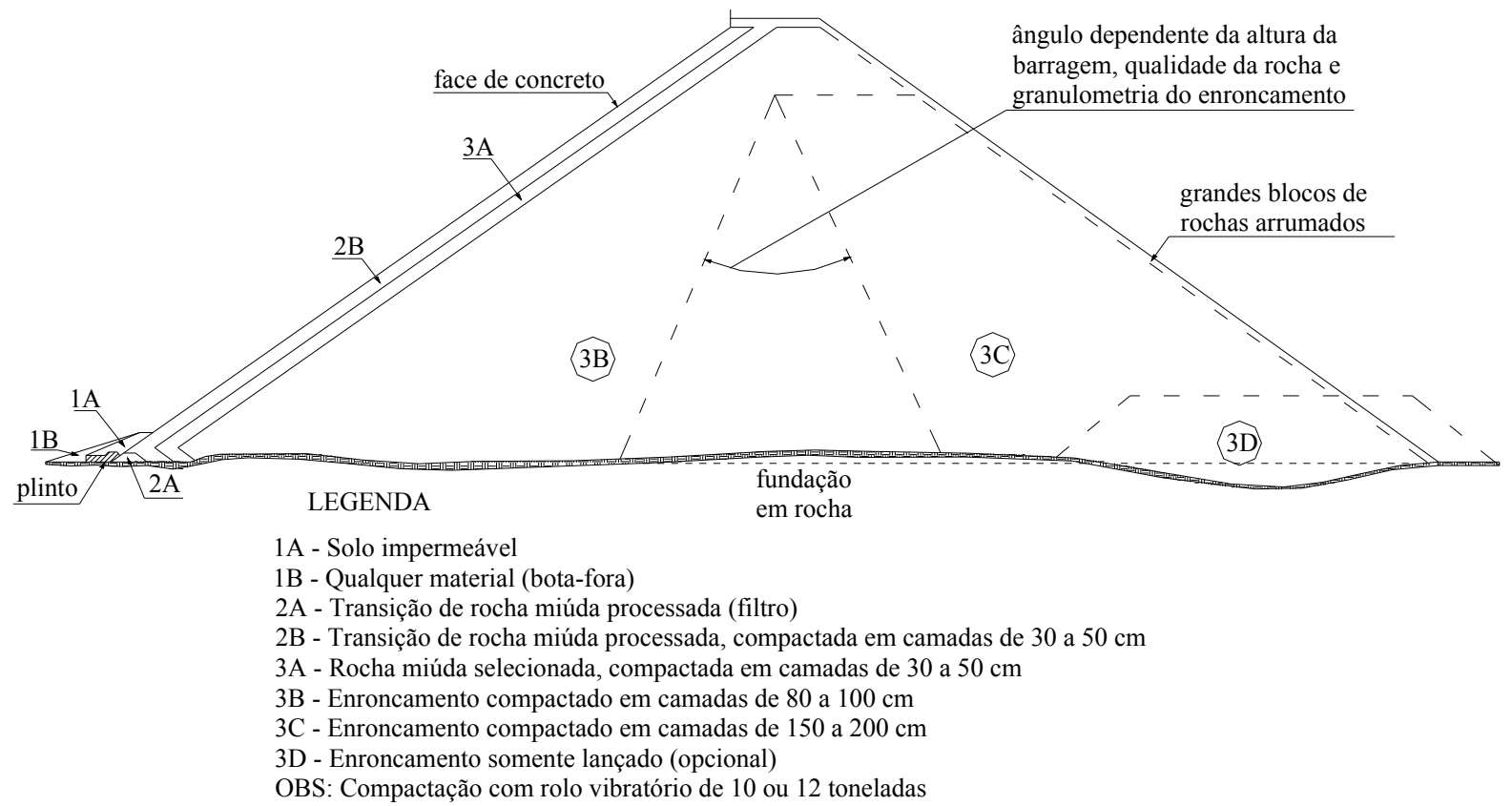

Figura 3. Zoneamento típico de BEFC, Cooke (1999).

\subsubsection{Zona 1}

A zona 1 refere-se a um manto de solo impermeável compactado a montante da laje de vedação. O objetivo é cobrir a junta perimetral e a laje nas cotas inferiores com solo impermeável, preferencialmente não coesivo o qual colmatará qualquer fissura ou abertura de junta. Uma espessura mínima de construção de silte e areia fina é usada sobre a laje e rocha de fundação (zona 1A), coberto com um material de bota-fora mais econômico para garantir a estabilidade (zona 1B).

\subsubsection{Zona 2}

A zona 2 é um enrocamento fino, britado com presença moderada de areia e finos. A largura da zona é reduzida e se localiza diretamente sob a face. O objetivo é conseguir um suporte firme e uniforme para a laje de concreto e estabelecer uma permeabilidade confiavelmente baixa, tendo uma granulometria aproximada de um material para filtro. A propriedade de semiimpermeabilidade é de grande valor nas proximidades das juntas perimetrais. Também para o 
caso de uma cheia durante a fase de desvio do rio, é esta zona que amenizará a percolação através do maciço em construção.

Esta zona é subdividida em 2A e 2B. A primeira localiza-se imediatamente abaixo da junta perimetral e possui uma granulometria capaz de reter a migração do silte proveniente da zona 1A, podendo conter um leve teor de cimento ( 3 a 4\%). A compactação é feita com compactador manual vibratório. A zona 2B refere-se a uma porção de $4 \mathrm{~m}$ de largura, compactada em camadas de 30 a $50 \mathrm{~cm}$ de espessura com rolo liso vibratório. Costuma-se especificar o método de compactação, ou seja, 4 a 6 passadas de um rolo de 10 ou 12 toneladas, sendo interessante determinar a massa específica para registro e controle. Para compactar a face, utiliza-se um rolo de menor dimensão que é puxado para cima, ao longo do talude, seguindo de mais quatro passadas sem vibração, ou até mesmo utilizar um vibrador de placa montado em uma retroescavadeira. É interessante proteger a superfície contra fortes chuvas a fim de evitar erosões. Algumas BEFC recentes introduzem uma guia de concreto extrusada (concreto fracamente cimentado), revestindo a zona $2 \mathrm{~B}$, com o objetivo de regularizar a superfície sob a laje de concreto e servir de forma para a compactação do material da zona $2 \mathrm{~B}$.

\subsubsection{Zona 3}

A zona 3 é a porção maior do maciço e esta é dividida em 3 subzonas (3A, 3B e 3C), com a espessura das camadas crescendo para jusante para se obter transições de compressibilidade e permeabilidade no sentido montante-jusante. Requer maior rigidez na porção de montante do maciço, que transmite a carga do reservatório à fundação.

A zona 3A é uma transição entre a zona 2 e o enrocamento principal, possui largura e espessura de camada similar à zona $2 \mathrm{~B}$. O objetivo principal dessa zona $3 \mathrm{~A}$ é o de limitar a dimensão dos vazios e assegurar que o material da zona 2 não seja arrastado para os grandes vazios do enrocamento principal.

Como a maior parte da carga d'água é transmitida através da porção de montante, é desejável que a compressibilidade da zona $3 \mathrm{~B}$ seja a mais baixa possível para minimizar as deflexões da laje de 
face. As experiências mostram que maciços construídos em camadas de até $1 \mathrm{~m}$ de espessura e compactado com 4 a 6 passadas de um rolo vibratório liso pesando 10t têm desempenho satisfatório.

A zona $3 \mathrm{C}$, por receber uma carga relativamente menor do que a zona $3 \mathrm{~B}$, é comumente constituída de camadas mais espessas, usualmente entre 1,5 e 2 m e também compactada com 4 passadas do mesmo rolo.

Em algumas regiões inferiores de jusante podem-se utilizar blocos de rocha somente lançados, quando abaixo do nível d'água (zona 3D). Na face de jusante são empurrados grandes blocos de rochas criando uma superfície esteticamente satisfatória e estável para o talude.

\subsubsection{Granulometria, qualidade do enrocamento e adição de água}

Para a maioria das formações rochosa dura, o enrocamento obtido de desmontes possui menos do que cerca de $30 \%$ de fragmentos menores do que $2,5 \mathrm{~cm}$. Por causa disso, tem sido comum especificar que o enrocamento não deve conter mais que $30 \%$ a $50 \%$ de fragmentos menores que 2,5 cm. As propriedades mais importantes dos maciços de BEFC são baixa compressibilidade e alta resistência ao cisalhamento. Dessa forma, qualquer desmonte de rocha dura com uma distribuição granulométrica média, tendo $20 \%$ ou menos de partículas passantes na peneira 4 $(4,76 \mathrm{~mm})$, e $10 \%$ ou menos passantes na peneira $200(0,074 \mathrm{~mm})$, terá alta resistência e baixa compressibilidade.

As considerações acima se relacionam a uma rocha de origem de alta resistência a compressão simples (acima de $300 \mathrm{kgf} / \mathrm{cm}^{2}$ ). A aceitabilidade de rochas mais friáveis é válida para a porção de jusante do maciço, Zona $3 \mathrm{C}$, sendo que na região de montante é adequado que pelo mesmo 70 $\%$ do material seja de origem de rochas duras.

A adição de água melhora sempre a propriedades de enrocamento, principalmente quando a rocha apresenta alta absorção de água. A finalidade principal é minimizar os recalques pós- 
construtivos. A quantidade de água aplicada tem sido comumente de 10 a $30 \%$ do volume do enrocamento.

\subsubsection{Plinto}

O plinto é uma estrutura de concreto localizada no pé da barragem e se extende por todo o perímetro de montante. Sua função é dar apoio à laje de concreto e definir condições de estabilidade da fundação, já que o gradiente hidráulico sob este tende a ser elevado. Assim, o plinto deve ser assente sobre uma rocha sã, não erodível e injetável. Sobre uma rocha menos favorável é necessário o tratamento das imperfeições para eliminar a possibilidade de erosão ou piping na fundação.

Para fundação em rocha dura e injetável, as larguras do plinto têm sido da ordem de 1/20 a 1/25 da carga da água do reservatório. A largura mínima tem sido geralmente de $3 \mathrm{~m}$, sendo que para condições de rochas de fundação pobre, as dimensões devem ser mais conservativas. A espessura de projeto tem sido, freqüentemente, igual à da laje da face, considerando uma espessura mínima de 0,3 a 0,4 m. A pressão da água na laje da face abre a junta perimetral e, portanto, não há interação entre o plinto e a laje.

A escavação no local deve ser executada cuidadosamente para minimizar o fraturamento da superfície da rocha sobre a qual o plinto é colocado. Um pouco antes da colocação do concreto é necessária a limpeza da rocha com um jato de ar, ou de ar e água, para se obter uma superfície de contato que facilite a ligação do concreto com a fundação. Sua disposição é como uma série de segmentos retos. Os vértices dos ângulos são selecionados para se adaptar às condições de fundação e topografia, e não têm qualquer relação exigida com as juntas verticais da laje da face.

A armadura é a mesma da laje da face, isto é, funciona como ferragem de temperatura e minimiza a largura de qualquer fissura que tenda a se desenvolver com as pequenas deformações de flexão. A armadura é colocada 10 a $15 \mathrm{~cm}$ da superfície superior, onde é interligada à ancoragem: 0,3\% em cada direção é adequado. A finalidade da ancoragem é simplesmente prender o concreto na 
rocha, não tendo a finalidade para resistir a qualquer carga de subpressão, porém podem dar uma contribuição na prevenção da subpressão durante as injeções.

As injeções são executadas com o plinto servindo como tampão de caldas e em qualquer época durante a construção. Ambos os pontos são importantes para um cronograma mais curto e custos mais baixos. As especificações não devem exigir que as injeções sejam executadas antes da colocação do enrocamento adjacente. Em especial, deve sempre ser exigido que as injeções sejam executadas através do plinto, injetando-se com mais eficiência a zona superior da rocha sob o plinto.

As injeções consistem de uma cortina profunda, com uma linha central de furos de injeção, mais as linhas de injeções de consolidação a montante e a jusante da cortina e de menores profundidades. As injeções de consolidação são de especial importância, por causa do caminhamento relativamente curto da percolação através da rocha e diretamente sob o plinto. A exigência é que a consolidação seja executada até uma profundidade suficiente para penetrar todas as zonas que apresentam superfícies de fissuras abertas de alta permeabilidade.

Quando a fundação é composta por rocha alterada, saprolito ou aluvião, alguns cuidados com relação aos elevados gradientes devem se tomados. Dessa forma, é aceitável aumentar o caminho de percolação através de uma camada de concreto projetado que venha impermeabilizar a superfície a jusante do plinto até a zona 2A. Uma parede diafragma conectada ao plinto também pode ser eficiente para controlar os efeitos de erosão em fundação de aluvião, assim como a utilização de drenos.

\subsubsection{Laje de concreto da face}

Para o concreto, a durabilidade e a impermeabilização são mais importantes que a resistência. Considera-se adequada uma resistência de cerca de 20 a $30 \mathrm{MPa}$ e agregado com dimensão máxima de $38 \mathrm{~mm}\left(1^{1} / 2\right.$ ”), incorporação de ar e utilização de pozolana são características comuns na prática atual. 
A espessura da laje nas primeiras barragens de enrocamento lançado era tradicionalmente igual a $0,3 \mathrm{~m}+0,0067 \mathrm{H}$. Atualmente, com o enrocamento compactado, o incremento da espessura foi reduzido para $0,003 \mathrm{H}$ ou mesmo para $0,002 \mathrm{H}$. Com base na experiência e prática atualmente disponíveis, é razoável projetar as lajes com uma espessura constante de 25 ou $30 \mathrm{~cm}$ para barragens de altura moderada (cerca de 75 a $100 \mathrm{~m}$ ) e usar uma espessura incremental de cerca de $0,002 \mathrm{H}$ para barragens altas e importantes. No entanto, devido a alguns incidentes de trincamento da laje próximo ao perímetro em barragens de alturas superiores a $100 \mathrm{~m}$, tem-se adotado uma espessura de $0,3+0,002 H(H<100)$ ou $0,005 \mathrm{H}(H>100)$ para as barragens muito altas.

A aplicação de $0,4 \%$ de aço em cada direção para faces de barragens de enrocamento compactado, ao invés dos tradicionais $0,5 \%$ usados em faces de barragens de enrocamento só lançado, foi uma mudança econômica bem sucedida. Para várias barragens recentes, $0,3 \%$ de aço é previsto em grande área central reconhecidamente de compressão, sendo 0,4\% mantido próximo ao perímetro.

As juntas verticais centrais tendem a permanecerem fechadas, enquanto que as de ombreira abrem. Dessa forma, devem ser instaladas veda-juntas de cobre na base das placas, instalados sobre uma base de argamassa e, atualmente, são utilizados alguns tipos de selante na parte superior das juntas (Mori \& Sobrinho, 1999). A junta perimetral sempre se abre e se desloca moderadamente no enchimento do reservatório e é um forte potencial de vazamento se não for bem projetada e construída. É necessário instalar 2 a 3 veda-juntas separados. As juntas verticais próximas às ombreiras e as juntas perimetrais recebem, além do dispositivo selante citado acima, um mastique (mistura densa, impermeável, de asfalto, agregado mineral e pó de pedra) superficial coberto firmemente com uma manta polimérica (borracha sintética ou PVC), cuja função é colmatar as juntas, mesmo quando estas sofrerem grandes deslocamentos.

As lajes da face têm sido construídas em faixas verticais com as fôrmas deslizando continuamente de baixo para cima usando juntas de construção horizontais. As lajes têm sido concretadas em faixas de 12 a $18 \mathrm{~m}$, sendo que a escolha deve ser deixada para o empreiteiro. 


\subsubsection{Instrumentação}

A instrumentação de BEFC tem sido importante para se ganhar conhecimentos e conduzir melhorias no projeto e no zoneamento do enrocamento. Assim, os resultados têm dado confiança para futuras barragens de maiores alturas. Os instrumentos se resumem basicamente em medidores de recalques baseados em níveis d'água, extensômetros horizontais, marcos superficiais, medidores de juntas e instrumentação para medição das tensões e deformações da laje de concreto da face (eletroníveis). Detalhes de instrumentação, procedimento de instalação e método de interpretação de leitura podem ser encontrados em Penman \& Rocha Filho (2001).

\subsection{Pratica Usual de Previsão do Comportamento de Deformação do Maciço}

A pratica atual de análise numérica da deformabilidade do maciço de enrocamento de BEFC utiliza como referência os parâmetros de deformação do maciço obtidos a partir dos resultados da instrumentação. Segundo Oliveira (2005), duas medições são avaliadas, primeiramente observam-se os recalques do maciço durante o período construtivo e posteriormente busca-se a determinação da configuração da deformada da laje de face de montante durante a fase de enchimento do reservatório.

\subsubsection{Módulo de deformabilidade durante a construção}

Durante a fase de construção são instalados medidores de recalques, geralmente do tipo de placas magnéticas, que fornecem os deslocamentos verticais de cada placa em relação à placa de referência instalada no maciço rochoso de fundação. $\mathrm{O}$ recalque de cada placa $\Delta H$ é calculado pela diferença entre a cota de instalação da placa e a cota da mesma em um dado instante (Equação 1):

$$
\Delta H^{\text {placa }(n)}=\operatorname{Cota}^{\substack{\text { placa }(n) \\ \text { instalação }}}-\operatorname{Cota}^{\substack{\text { placa }(n) \\ \text { instante }(t)}}
$$


O recalque de uma determinada camada compreendida por duas placas pode então ser calculado pela diferença entre o recalque da placa superior e o recalque da placa inferior, a partir do instante da instalação da placa superior, ou seja, somente é computado o recalque ocorrido a partir do instante em que toda a camada passa a ser carregada (Equação 2):

$$
\Delta H^{\text {camada }}=\Delta H^{\text {placa (n) }}-\Delta H^{\text {placa } \text { instalaçąa placa }(n)}
$$

A deformação $\varepsilon$ de cada camada compressível entre placas é obtida pela relação entre o recalque e a espessura da camada $H$, como segue a Equação 3 .

$$
\varepsilon_{\text {camada }}(\%)=\frac{\Delta H^{\text {camada }}}{H} \times 100
$$

Com a evolução do alteamento do aterro em relação às placas, considera-se que a tensão atuante $\sigma$ no centro de cada camada é correspondente ao peso da coluna de enrocamento sobre este ponto (Equação 4):

$$
\sigma=\left(H_{\text {enroc }}-H_{\text {camada }}\right) \times \gamma_{\text {enroc }}
$$

Dessa forma, a relação entre a tensão atuante $\sigma$ e a deformação específica $\varepsilon$ medida pela instrumentação na camada de análise chama-se módulo de deformabilidade de construção $E_{\text {const }}$ ou módulo construtivo (Equação 5).

$$
E_{\text {const }}^{\text {camada } n}=\frac{\sigma^{\text {camada } n}}{\varepsilon^{\text {camada } n}}
$$

Vale considerar que o módulo calculado acima pode ser incorreto, pois os valores das cargas atuantes em cada camada nem sempre equivalem ao peso da coluna de enrocamento, tendo a influência, por exemplo, do formato do vale e do arqueamento. 


\subsubsection{Módulo de deformabilidade durante o enchimento do reservatório}

No período de enchimento do reservatório, há a preocupação de se medir as deflexões da face de concreto no parâmetro de montante. Para isso, é usual a utilização de eletroníveis, que são dispositivos compostos por cápsula contendo líquido eletrolítico e transdutores elétricos capazes de fornecerem dados de rotação em diferentes pontos através de uma linha longitudinal na laje de concreto. A integração numérica ou o ajuste polinomial dos resultados de rotação em função da distância de instalação dos aparelhos fornece uma configuração das deformações normais à face ao longo da laje (Goulart, 2004).

O módulo de deformabilidade durante o enchimento do reservatório $E_{\text {ench }}$, também denominado de módulo de deformabilidade da seção transversal perpendicular ao parâmetro $E_{\text {trans }}$, é definido como a relação entre a tensão atuante sobre um dado ponto da face de concreto e a deformação $\varepsilon_{\text {trans }}$ da camada compressível sob esse ponto perpendicular à face, sendo que a tensão atuante $\sigma_{\text {trans }}$ é determinada pela carga hidrostática do reservatório, e a deformação $\varepsilon_{\text {trans }}$ é dada pela relação entre o deslocamento $\delta$ e a espessura da camada compressível $D$, conforme apresentado na Figura 4 e nas Equações 6, 7, 8 e 9.

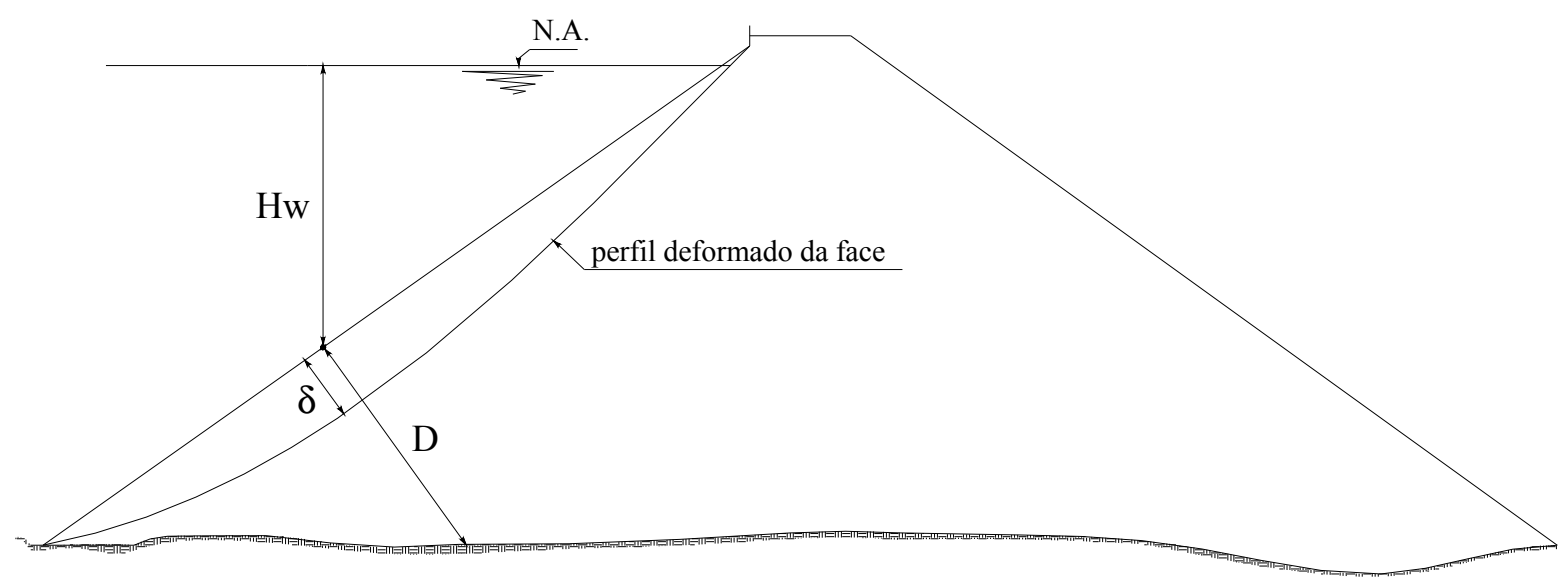

Figura 4. Método de cálculo do módulo de enchimento.

$$
\begin{gathered}
\sigma_{\text {trans }}=E_{\text {ench }} \times \varepsilon_{\text {trans }} \\
\sigma_{\text {trans }}=\gamma_{w} \times H_{w}
\end{gathered}
$$




$$
\begin{gathered}
\mathcal{E}_{\text {trans }}=\frac{\delta}{D} \\
E_{\text {ench }}=\frac{H_{w} \times D \times \gamma_{w}}{\delta}
\end{gathered}
$$

Cabe mencionar que o modelo acima apresentado admite que o módulo de deformabilidade calculado seja um módulo médio, uma vez que leva em conta regiões do enrocamento com características distintas, tanto de energia de compactação e granulometria quanto de diferentes estados e trajetórias de tensões ao qual o material é submetido.

\subsection{Casos históricos, referências e comentários sobre o comportamento de deformação de BEFCs.}

Este tópico tem como referência os artigos Marulanda \& Pinto (2000) - "Recent Experience on Design, Construction and Performance of CFRD Dams", Marques Filho \& Pinto (2004) “CFRD Dam Characteristics Learned From Experience" e Pinto \& Marques Filho (1998) "Estimating the maximum face deflection in CFRDs". Alguns comentários e discussões são feitos a respeito do comportamento de deformação do maciço de enrocamento em barragens que tiveram algum tipo de problema relacionado à deformação.

Os vazamentos conseqüentes das fissuras na laje e abertura das juntas perimetrais e verticais observadas nas recentes BEFC estão relacionados com as deformações diferenciais do maciço durante a construção e enchimento do reservatório. Como conseqüência da saturação ou umedecimento do maciço em algumas zonas, é possível que as deformações do maciço continuem durante a operação do reservatório.

Outras possíveis causas que levam ao fissuramento da laje de concreto na BEFC, além dos efeitos de deformação diferencial do maciço resultante das diferentes alturas de camadas compactadas, são:

- Seqüência construtiva assimétrica na fase de alteamento, que pode levar a formação de trincas na região de transição (zona 2B); 
- Efeito da geometria da fundação;

- Mudança brusca da inclinação das ombreiras;

- Efeito de "pulsão" na laje durante o enchimento, resultando em regiões de tração próximas às ombreiras e de compressão no centro da laje.

Algumas ocorrências de fissura na laje e vazamento pelo maciço em barragens recentes, acima de $100 \mathrm{~m}$ de altura, são abordadas em seguida.

\subsubsection{Aguamilpa}

Essa barragem, localizada no México, possui $187 \mathrm{~m}$ de altura e revelou fissuras sub-horizontais no terço superior da face de concreto. Os vazamentos, medidos na base, atingiram $257 \mathrm{l} / \mathrm{s}$. O maciço é composto por cascalho compactado na zona de montante, sendo que na zona de jusante utilizou-se enrocamento. Foram verificados valores de módulo construtivo igual a $260 \mathrm{MPa}$ para o material de montante, enquanto que o enrocamento de jusante apresentou valor de $47 \mathrm{MPa}$. A deflexão da face e o zoneamento do maciço dessa barragem estão apresentados na Figura 5. A grande diferença de rigidez entre as duas zonas do maciço foi a principal causa da ocorrência de fissuras na parte superior da laje, Marques Filho \& Pinto (2004). 


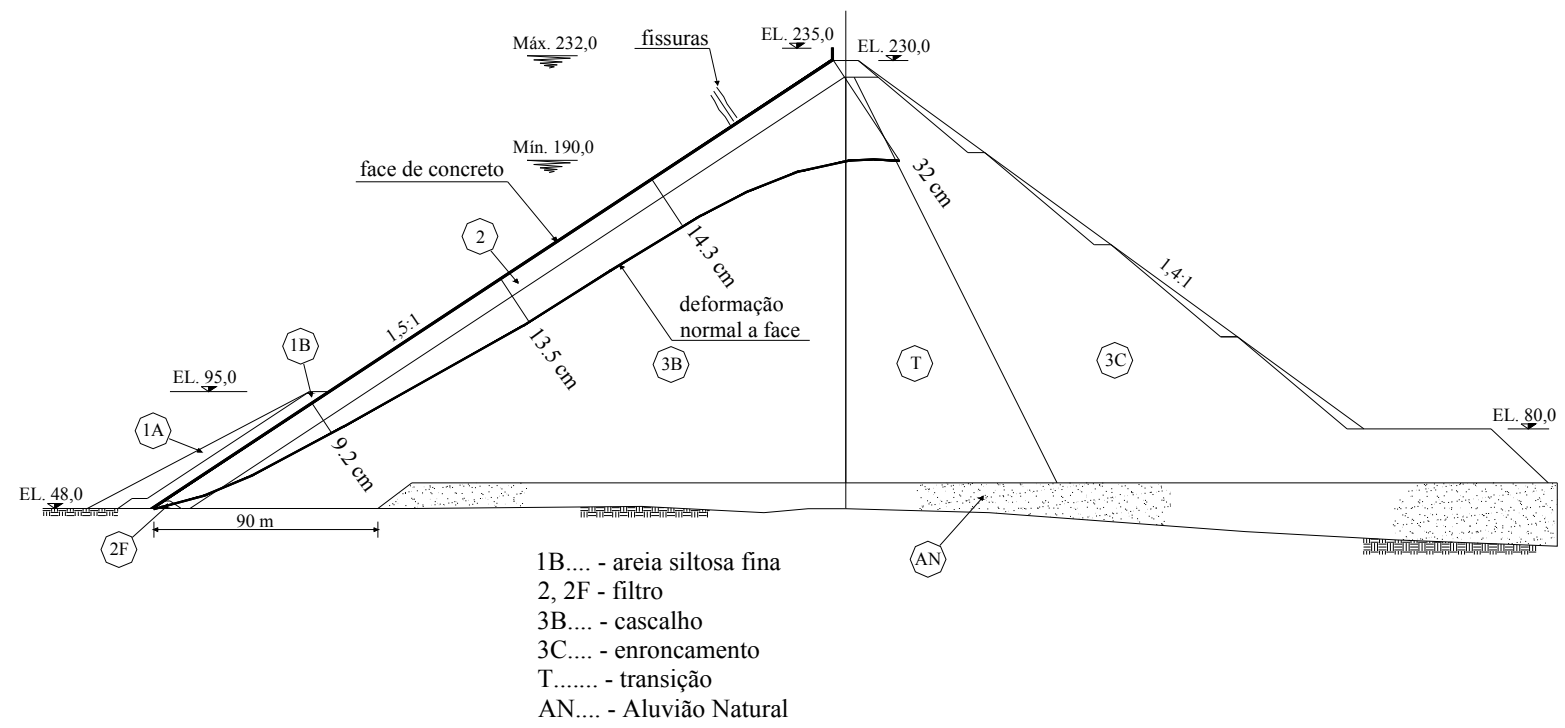

Figura 5. Barragem de Aguamilpa: seção do zoneamento do maciço e deflexão da laje, Marques Filho \& Pinto (2004).

\subsubsection{Xingó}

A barragem de Xingó, no Brasil, com $150 \mathrm{~m}$ de altura, apresenta enrocamento proveniente de gnaisse na zona $3 \mathrm{~B}$, compactado em camadas de $1,00 \mathrm{~m}$, enquanto que na zona $3 \mathrm{C}$ as camadas foram compactadas com espessura de 2,00 $\mathrm{m}$ e com um material proveniente de uma rocha de pior qualidade. Na zona 2, seguindo as recomendações de Sherard, foi utilizado alto teor de areia, bem como um teor de finos, não superior a $12 \%$. Durante o alteamento, fissuras na superfície da zona 2 (porção de enrocamento fino sob a laje) eram observadas junto à ombreira esquerda. $\mathrm{Na}$ parte superior da ombreira esquerda, a montante, existe uma rocha entalhada que produz significativas diferenças na elevação da fundação.

Os módulos de deformação na fase construtiva, calculados a partir de medidas determinadas, mostram diferenças significativas entre as duas zonas. Em algumas áreas, valores tão altos como $68 \mathrm{MPa}$ eram medidos na zona 3B e apenas $24 \mathrm{MPa}$ para zona 3C. Fissuras construtivas foram explicadas pelas deformações diferenciais entre as diferentes zonas do maciço e regiões 
tracionadas próximas às ombreiras. Essas fissuras foram preenchidas antes da concretagem da laje.

Com o enchimento do reservatório, observou-se que vazamentos através do maciço oscilavam entre 110 e 160 1/s com a variação do nível d'água do reservatório. Observou-se que havia fissuras na margem esquerda que chegavam além da zona granular de transição. $O$ fato foi explicado pela característica geométrica da fundação e pelo alto teor de finos na zona de transição.

É interessante notar que, após o reservatório atingir o nível máximo, a movimentação da laje continuou a se processar durante alguns anos (Figura 6). Mesmo estando sob solicitação constante, o maciço continuou a se deformar, talvez por efeito de colapso e fluência em regiões do maciço de enrocamento, onde houve alteração do teor de água proveniente de vazamento através da laje (Penman e Rocha Filho 2001).

\begin{tabular}{|c|c|c|}
\hline XINGÓ & \multicolumn{2}{|c|}{ DEFLEXÃO (m) } \\
\hline ELEV. (m) & $11 / 94$ & $05 / 00$ \\
\hline (EL 1) 48 & 0,08 & 0,23 \\
\hline$(E L 2) 64$ & 0,24 & 0,38 \\
\hline (EL 3) 80 & 0,29 & 0,46 \\
\hline (EL 4) 88 & 0,26 & 0,47 \\
\hline (EL 5) 96 & 0,24 & 0,48 \\
\hline (EL 6) 104 & 0,23 & 0,49 \\
\hline$(\mathrm{EL} 7) 112$ & 0,22 & 0,48 \\
\hline (EL 8) 120 & 0,20 & 0,45 \\
\hline (EL 9) 127 & 0,18 & 0,45 \\
\hline (EL 10) 138 & 0,17 & 0,51 \\
\hline
\end{tabular}

$(64 \mathrm{~m})$ EL2

$(48 \mathrm{~m})$

EL1

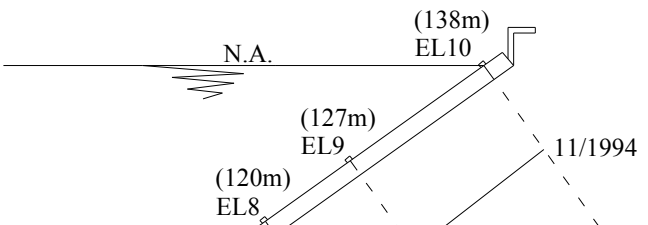

$$
\begin{aligned}
& (112 \mathrm{~m}) \\
& \mathrm{EL} 7
\end{aligned}
$$

$(104 \mathrm{~m})$

EL6

$(96 \mathrm{~m})$

EL5

$(88 \mathrm{~m})$

EL4

$(80 \mathrm{~m})$

EL3

DFORMADA DA LAJE

(ELETRONÍVEIS)

Figura 6. Barragem de Xingo: deformada da laje no período de operação (pós-construtivo), Penman \& Rocha Filho (2001). 


\subsubsection{Itapebi}

Itapebi é uma barragem brasileira construída na Bahia com $100 \mathrm{~m}$ de altura. Após o enchimento, foi constatada uma vazão de 900 1/s na base a jusante da barragem. Uma investigação subaquática detectou fissuras paralelas ao plinto em 4 lajes da face. As fissuras resultaram da deformação diferencial causada pela geometria da fundação na ombreira direita (Figura 7), assim como as observadas em Xingó. Após um tratamento com material siltoso, as vazões reduziram para $100-$ $150 \mathrm{l} / \mathrm{s}$.

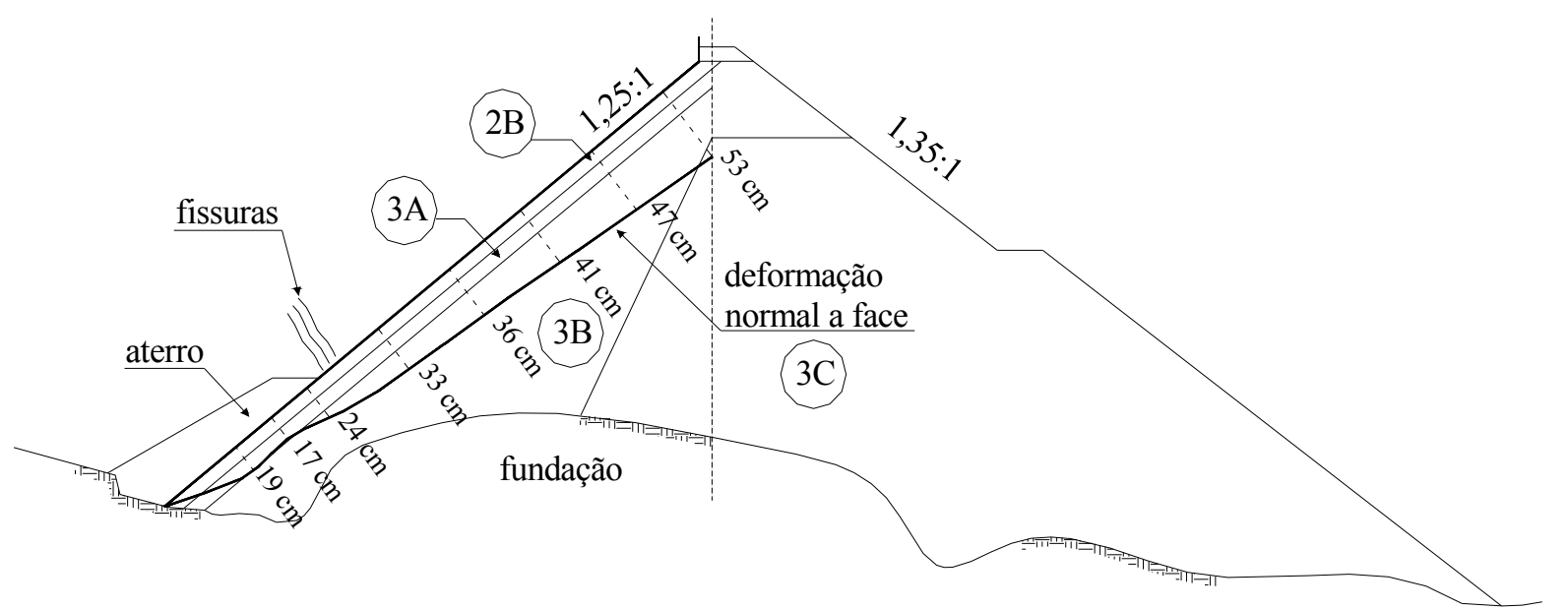

Figura 7. Barragem de Itapebi: seção do zoneamento do maciço e deflexão da laje na ombreira direita, Marques Filho \& Pinto (2004).

\subsubsection{Tianshengqiao}

A barragem de TSQ1 possui $180 \mathrm{~m}$ de altura e está localizada na China. Os mesmos critérios adotados em Xingó, na zona 2, foram adotados nessa barragem, ou seja, com teor de finos variando entre 10 e $15 \%$. Fissuras com abertura de até $10 \mathrm{~cm}$ foram observadas na zona de transição durante a construção. Posteriormente, essas fissuras foram tratadas com uma calda composta por $5 \%$ de cimento e $95 \%$ de fly ash. As deformações diferenciais e o alto teor de finos explicam a ocorrência dessas fissuras. 


\subsubsection{Itá}

A barragem de Itá, construída no rio Uruguai, divisa dos estados de Santa Catarina e Rio Grande do Sul, possui $125 \mathrm{~m}$ de altura e foi concluída em 2000. Após o primeiro enchimento, vazamentos de até 1700 1/s foram detectados. Após uma investigação subaquática detectaram-se fissuras de até $15 \mathrm{~m}$ de comprimento paralelas e próximas ao plinto. A causa do problema não foi claramente identificada. Com o lançamento de material siltoso, as fissuras foram parcialmente colmatadas e a vazão através do maciço reduziu para 200 1/s. A Figura 8 mostra o zoneamento do maciço e a configuração da deformada da laje.

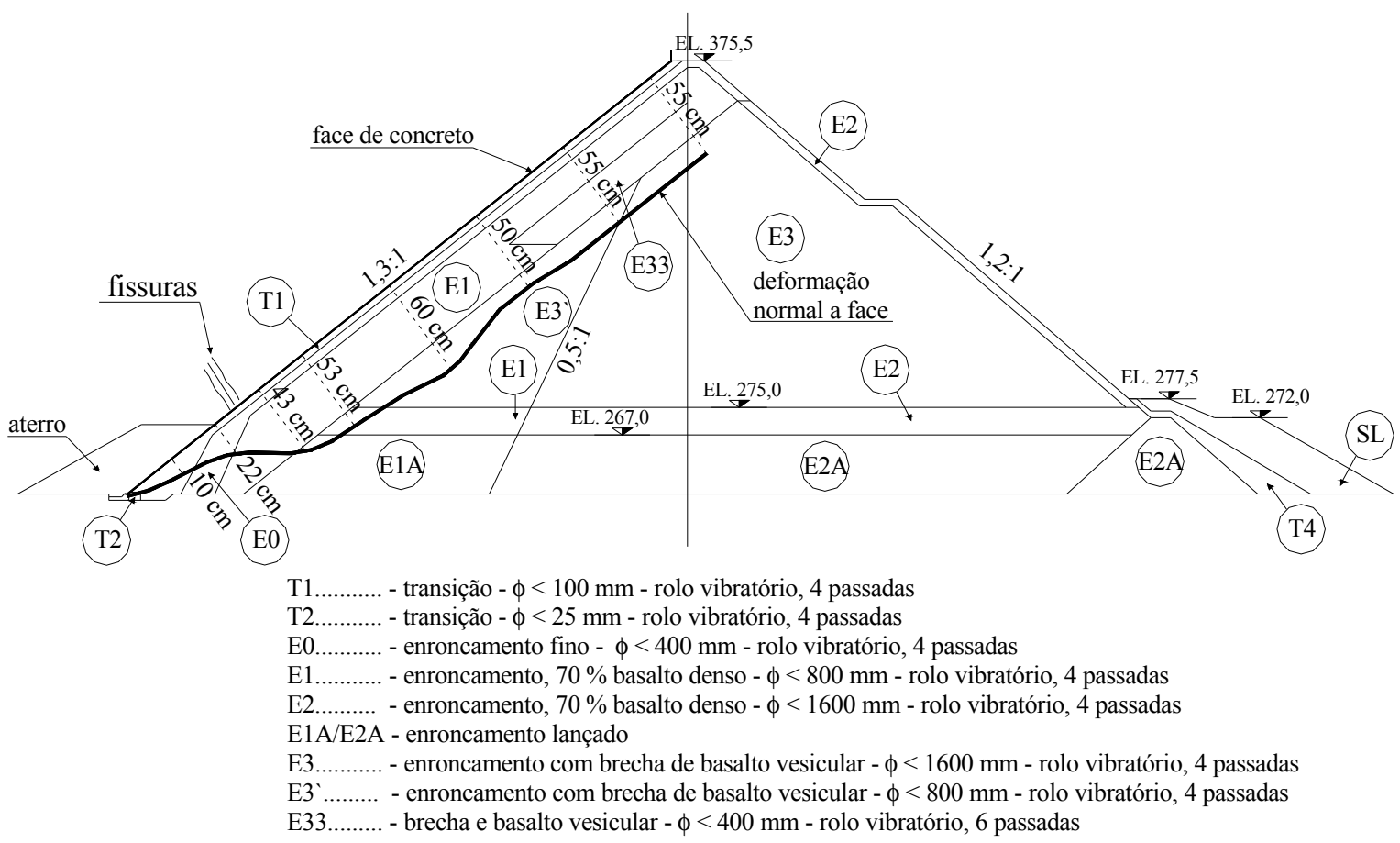

Figura 8. Barragem de Itá: seção do zoneamento do maciço e deflexão da laje, Oliveira (2005). 


\subsubsection{Dados de algumas BEFC}

Resumidamente são apresentados na Tabela 1 dados característicos de algumas das principais BEFC no Brasil e no mundo com os valores das deflexões máximas da laje e na crista e valores dos módulos de construção e de enchimento.

Tabela 1. Alguns parâmetros de construção e comportamento de BEFCs, Pinto \& Marques Filho (1998).

\begin{tabular}{|c|c|c|c|c|c|c|c|c|c|c|c|}
\hline Barragem & País & Ano & $\begin{array}{c}\text { Altura } \\
\text { (m) }\end{array}$ & $\begin{array}{c}\text { Tipo de } \\
\text { rocha }\end{array}$ & $\begin{array}{c}L \\
(m)\end{array}$ & $\begin{array}{c}\mathrm{A}\left(10^{3}\right. \\
\left.\mathrm{m}^{2}\right)\end{array}$ & $\begin{array}{c}\text { Ev } \\
(\mathrm{Mpa})\end{array}$ & $\begin{array}{c}\mathrm{D} \\
(\mathrm{m})\end{array}$ & Vaz. (1/s) & $\begin{array}{c}E T \\
(M p a)\end{array}$ & $E T / E v$ \\
\hline Cethana & Australia & 1971 & 110 & Quartzo & 213 & 24 & 135 & 0,12 & 7 & 300 & 2,2 \\
\hline A. Anchicaya & Colombia & 1974 & 140 & Diorita & 260 & 22 & 145 & 0,13 & $1800 / 180$ & 440 & 3,0 \\
\hline Foz do Areia & Brasil & 1980 & 160 & Basalto & 828 & 139 & 32 & 0,69 & $236 / 60$ & 110 & 3,4 \\
\hline Salvagina & Colombia & 1984 & 148 & Cascalho & 330 & 50 & 390 & 0,1 & 60 & 630 & 1,6 \\
\hline Golillas & Colombia & 1984 & 130 & Cascalho & 125 & 14 & 210 & 0,16 & $1080 / 650$ & 310 & 1,5 \\
\hline Shiroro & Nigéria & 1984 & 125 & Granito & 560 & 65 & 76 & $*$ & $1800 / 100$ & $*$ & * \\
\hline Khao Laem & Tailândia & 1984 & 130 & Limestone & 1000 & 140 & 45 & 0,13 & 53 & 380 & 8,4 \\
\hline Lower Pieman & Australia & 1986 & 122 & Dolorita & * & 35 & 160 & 0,22 & * & 200 & 1,3 \\
\hline Aguamilpa & México & 1993 & 187 & Cascalho & 660 & 137 & 190 & 0,15 & $260 / 100$ & 680 & 3,6 \\
\hline Segredo & Brasil & 1993 & 140 & Basalto & 705 & 86 & 45 & 0,34 & $400 / 50$ & 170 & 3,8 \\
\hline Xingó & Brasil & 1994 & 140 & Granito & 850 & 135 & 37 & 0,3 & 180 & 190 & 5,1 \\
\hline Itá & Brasil & 1999 & 125 & Basalto & 880 & 110 & 29 & 0,75 & 1700 & * & 0,0 \\
\hline Machadinho & Brasil & 2002 & 125 & Basalto & 700 & 77 & 31 & 0,37 & * & 71 & 2,3 \\
\hline Itapebi & Brasil & 2003 & 120 & Gnaisse & $*$ & $*$ & 60 & 0,4 & * & * & $*$ \\
\hline
\end{tabular}

* Dados não publicados ou não encontrados nas literaturas consultadas. 


\section{DEFORMABILIDADE DE ENROCAMENTOS}

\subsection{Introdução}

As estruturas de enrocamentos podem apresentar problemas quanto à deformabilidade, que podem resultar em estados limites de funcionalidade. Quanto à estabilidade, é raro isto ser uma questão determinante. A resistência ao cisalhamento da massa de enrocamento é sempre suficiente para mantê-la em equilíbrio estático. Por isso, apenas análises dinâmicas de estabilidade são executadas durante o projeto, De Mello (1977). Dessa forma, este capítulo enfatizará, principalmente, os fenômenos ligados à deformabilidade do enrocamento compactado.

As pesquisas, investigações e o estudo com relação ao enrocamento compactado incidiram, principalmente, sobre resistência e deformação, quer através de observações de campo, quer através de estudos em laboratório, sempre com base no comportamento mecânico do material.

\subsubsection{Definição de enrocamento}

As primeiras utilizações do enrocamento como aterros ocorreram durante a segunda metade do século XIX na Califórnia com o objetivo de armazenar água para operações de mineração. No início do século XX, surgiram as primeiras barragens, sendo estas aterros não compactados e com granulometria com baixo valor de coeficiente de uniformidade. A partir de meados do século XX, começou a surgir o enrocamento compactado em camadas delgadas com rolo vibratório, resultando em um maciço mais denso e homogêneo, diminuindo os recalques pós-construtivos e as distorções na face impermeável, Penmam (1992) e Gaioto (1997).

Nos dias de hoje, o enrocamento utilizado em barragens é um material constituído principalmente por blocos rochosos com dimensões apreciáveis, obtidos através de desmonte de maciços rochosos e posteriormente processados em britadores. De acordo com Maranha das Neves (2002), a porcentagem de fragmentos com dimensão inferior a 0,074 mm (\# 200, ASTM) não 
deve exceder $10 \%$ e a dimensão máxima dificilmente ultrapassa $1000 \mathrm{~mm}$. Freqüentemente, a porcentagem de partículas com dimensão superior a $50 \mathrm{~mm}$ é superior a $60 \%$, nesse caso, são os blocos de maior dimensão que controlam o comportamento do maciço. A Figura 9 apresenta a faixa granulométrica onde se devem encaixar as granulometrias dos chamados enrocamentos.

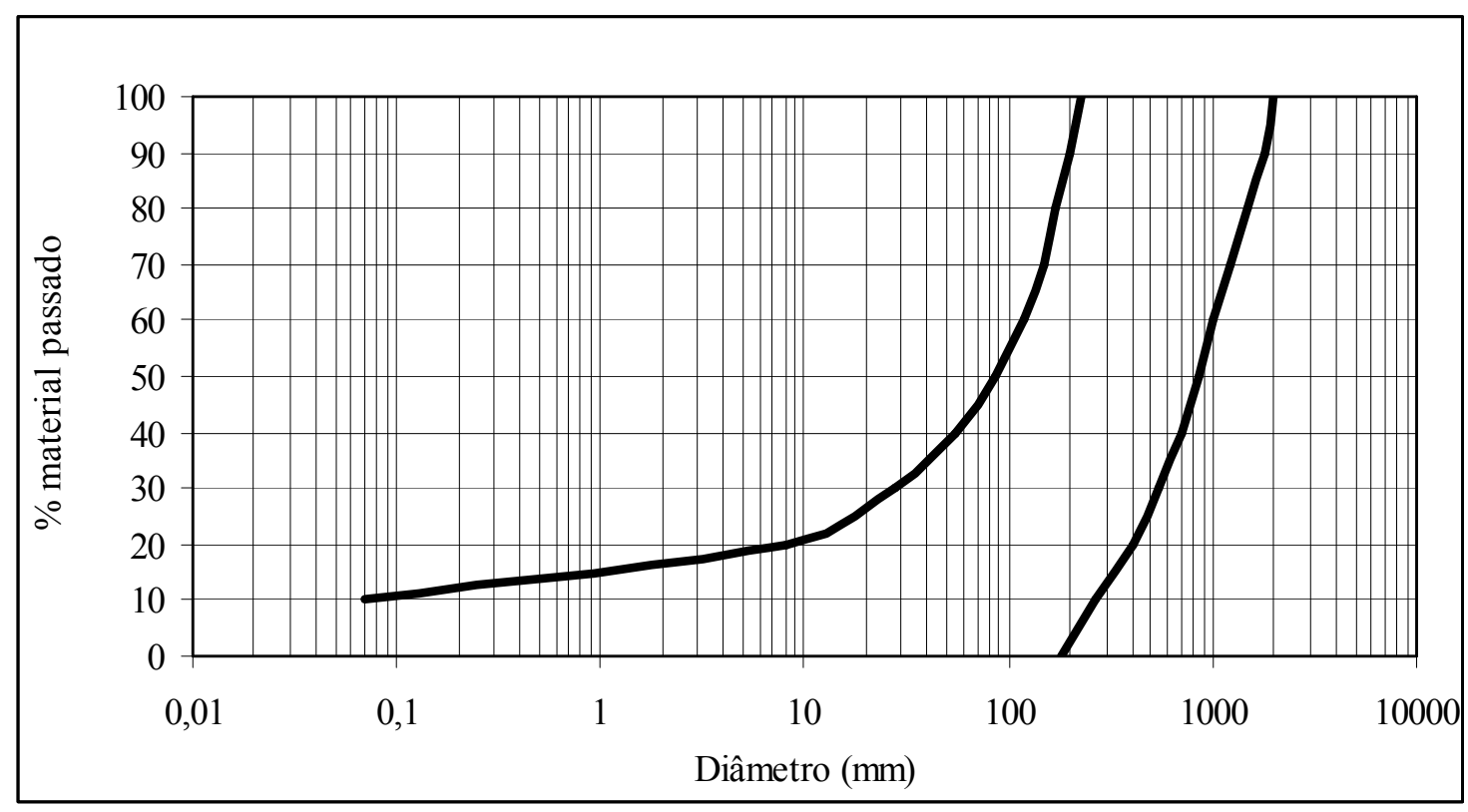

Figura 9. Faixa granulométrica dos chamados enrocamentos, Neves (2002).

\subsubsection{A importância de se estudar a deformação}

Embora não sendo uma solução tecnologicamente recente, os materiais de enrocamento têm obtido uma utilização crescente nas últimas décadas, principalmente na construção de barragens com face impermeabilizante. Fatores relacionados à metodologia construtiva e à viabilidade de projeto são responsáveis pela adoção desse tipo de barragens em determinados locais.

A evolução no projeto das BEFC tem sido baseada na experiência, como cita J. Barry Cooke no II Simpósio sobre BEFC (1999): "The design of the CFRD being base don experience can be considered to be empirical. Empirical is define as 'guided by practical experience and not theory'...”. No entanto, as barragens desse tipo estão cada vez mais altas e problemas como deformações diferenciadas no maciço têm sido o fator de maior preocupação do projeto 
geotécnico para esse tipo de barragem. A ocorrência de fissuras e abertura de juntas na laje de concreto provoca vazões elevadas, exigindo reparos custosos e demorados.

Alguns autores citam que as fissuras e aberturas de juntas na laje de concreto pouco importam para o desempenho das barragens. No entanto, Cruz (1999) dá uma relevância à observação dos deslocamentos nas barragens com o objetivo de aprender sobre o comportamento do enrocamento. As lajes não são feitas para trincar, até porque a conseqüência disso é a saturação parcial do enrocamento, podendo levar às deformações pós-contrutivas.

Contudo, é importante que estudos sobre deformabilidade de enrocamentos sejam propostos para que projetistas e construtores possam aperfeiçoar as previsões e melhorar as características do material compactado.

\subsubsection{Dificuldade de análise, busca de parâmetros e representatividade}

Nos últimos 30 a 40 anos, têm-se acentuado a importância da caracterização da mecânica dos solos nas análises tensão-deformação de barragens de aterro. Marsal (1977) menciona que deformações calculadas através de análises numéricas podem ser distintas dos valores observados e que a principal fonte de erro reside na quantificação dos parâmetros das equações constitutivas dos materiais, a partir de ensaios laboratoriais. Há a necessidade de um maior desenvolvimento da caracterização mecânica dos materiais, buscando uma melhor representatividade nas análises do comportamento estrutural de barragens.

A modelagem de amostras de enrocamento é muito mais complexa do que para outros materiais, já que, além de ser difícil simular o estado anisotrópico do enrocamento, o ângulo de atrito diminui e o fraturamento das partículas é maior, quando estas aumentam em dimensão. Por outro lado, é difícil de reproduzir os efeitos de pré-compressão causados pelos rolos vibratórios e sua influência nos parâmetros do enrocamento, Materon (1983). 


\subsection{Investigações de laboratório em amostras de enrocamento}

\subsubsection{Inter-relação e representatividade das condições de campo e laboratório}

Considerando as dificuldades envolvidas na preparação, compactação e instrumentação de uma amostra de enrocamento em tamanho real, é praticamente impossível de simular em laboratório as condições de campo. Porém, a aplicação de qualquer método de análise para barragens de enrocamento requer conhecimentos das propriedades de resistência e deformabilidade do material. Sendo assim, é necessário procurar alternativas que levem às informações necessárias. Essas alternativas normalmente envolvem ensaios laboratoriais em material de enrocamento que não apresentam o mesmo tamanho de partícula como no campo, Marachi et al. (1969).

Zeller \& Wulliman (1957) propuseram que, ensaiando diferentes amostras com diferentes granulometrias, é possível extrapolar os parâmetros obtidos para a granulometria de campo.

Veiga Pinto (1982) cita que, para uma amostra de enrocamento apresentar boa reprodutibilidade das condições de campo tem de possuir semelhança:

i. na granulometria;

ii. no estado de compacidade;

iii. na forma das partículas.

Os estudos laboratoriais de amostras de enrocamentos têm dificuldades relacionadas à dimensão de algumas de suas partículas. Devido à impossibilidade de moldagem de corpos de prova com amostras de enrocamentos obtidas no campo, é necessário analisar o efeito da dimensão das partículas em relação à dimensão da amostra ensaiada no laboratório. Veiga Pinto (1983) mencionou que, se a relação entre o diâmetro da amostra $D_{a}$ e o diâmetro máximo das partículas $D_{\max }$ for menor que 5, existirá uma elevada proporção de partículas com grandes dimensões, e os valores de resistência serão majorados devido à influência dessas partículas maiores. Entretanto, Holltz \& Gibbs (1956) concluíram que, se o número dessas partículas com dimensões 
máximas for inferior a $30 \%$ e a relação entre diâmetro da amostra e diâmetro máximo do enrocamento maior que 6 , o efeito da dimensão da amostra é desprezível.

Com relação à granulometria da amostra, existem basicamente 2 métodos a serem utilizados para a modelagem da curva granulométrica: curvas paralelas e com eliminação (Figura 10). O primeiro se refere a uma granulometria de ensaio paralela à de campo, com uma diferença de $\Delta D$, que representa a diferença entre o diâmetro máximo dos blocos de enrocamento em campo e o das partículas da amostra, cujo valor depende do tamanho da amostra. No segundo método, eliminam-se as frações do enrocamento de campo superiores ao diâmetro máximo das partículas da amostra e as substituem por partículas correspondentes ao mesmo peso de material dessa fração. Esses procedimentos devem ser analisados cuidadosamente, pois cada caso tem sua característica particular. Por exemplo, a utilização de curvas paralelas pode fornecer uma quantidade elevada de finos, o que deve mudar radicalmente o comportamento da amostra. $\mathrm{O}$ segundo método fornece uma amostra mais uniforme, que também tem influência no comportamento do enrocamento. Apesar dos finos, o método das curvas paralelas é o mais utilizado.

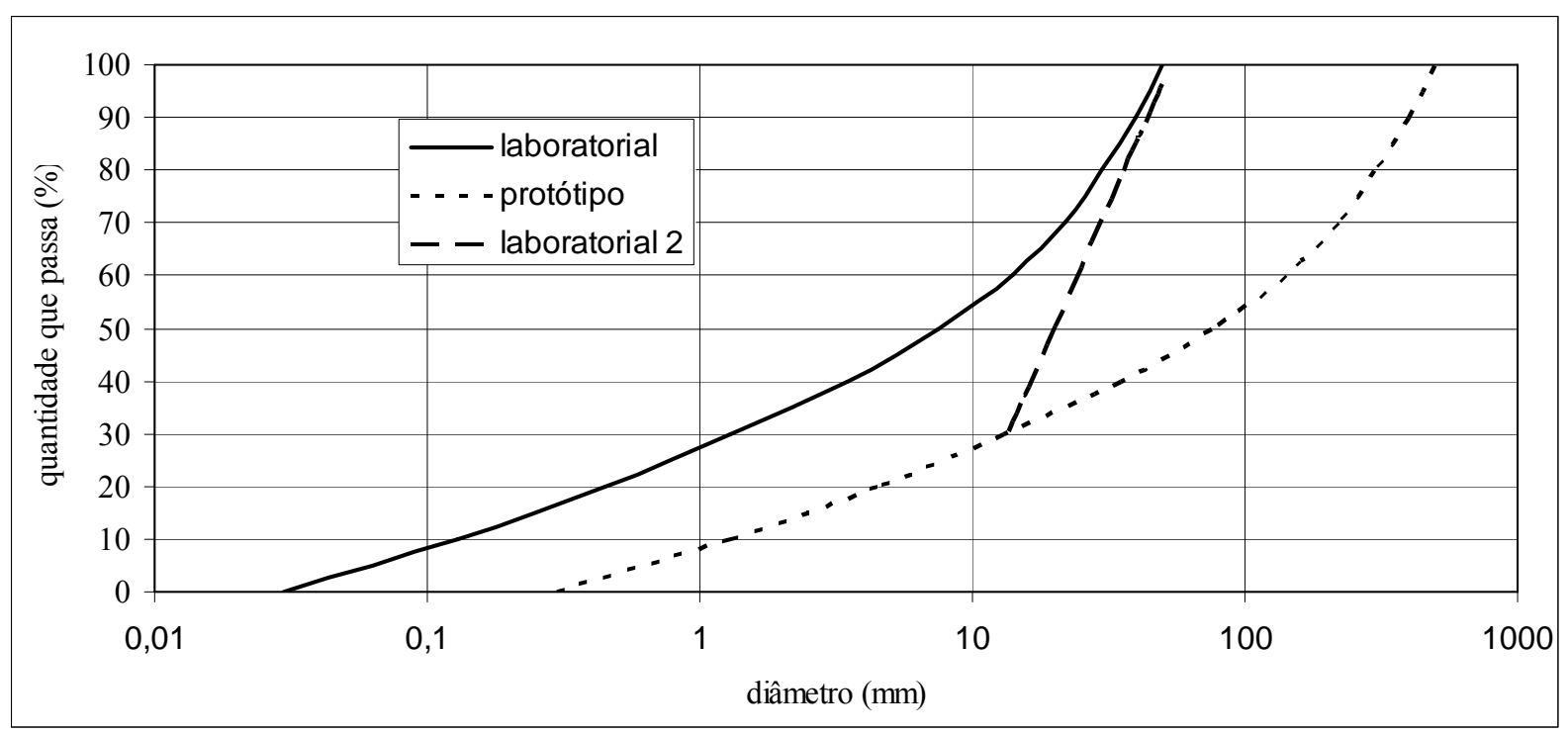

Figura 10. Método de modelagem da curva granulométrica de campo, Veiga Pinto (1982).

$\mathrm{O}$ formato das partículas pode ser avaliado através do coeficiente de forma $C_{f}$ que é a razão entre o volume dos grãos e o volume de uma esfera circunscrita no mesmo grão. Para Marsal (1973) o 
diâmetro das esferas teóricas tem sido definido pelo diâmetro médio das partículas, já Fumagalli (1969) define pelo seu diâmetro máximo. Assim $C_{f}$ é expressa pela Equação 10.

$$
\mathrm{C}_{\mathrm{f}}=\frac{\sum_{1}^{\mathrm{n}} \frac{\mathrm{P}}{\gamma_{\mathrm{dg}}}}{\sum_{1}^{\mathrm{n}} \frac{\pi}{6} \mathrm{D}^{3}}
$$

em que $P$ é peso médio dos grãos, $\gamma_{d g}$ é peso específico da rocha e $D$ é diâmetro médio ou diâmetro máximo das partículas. Dependendo da natureza e origem do material, o valor do coeficiente de forma varia entre 0,15 e 0,30 para a metodologia de Fumagalli (1969).

\subsubsection{Comportamento fenomenológico}

As deformações em aterros de enrocamento ocorrem basicamente devido a dois mecanismos, Penman (1982):

- Quebra dos contatos entre os blocos e até mesmo a quebra do próprio bloco;

- Rearranjo e reorientação dos blocos no interior do maciço.

A análise fenomenológica do enrocamento, do ponto de vista da relação tensão-deformação, pode ser obtida a partir de ensaios laboratoriais, analisando as deformações resultantes da alteração dos estados de tensão.

Quando se aplica certa tensão a uma amostra laboratorial ou se verifica a ruptura das partículas rochosas, se dá o deslizamento e rolamento de uma partícula em relação a outra, de forma a atingirem novos estados de equilíbrio. O deslocamento de uma partícula e a fraturação de outras são fenômenos que devem ocorrer simultaneamente.

A reação do material às deformações depende, sobretudo, da interferência, ou seja, do imbricamento que as partículas exercem entre si e do estado de tensão. O imbricamento entre partículas depende, por sua vez, da densidade do material. Em ensaios de deformações distorcionais verifica-se que, em amostras submetidas a baixas tensões de confinamento, 
acentuam-se as dilatâncias positivas, devido ao movimento relativo entre as partículas de rocha. Para elevadas tensões de confinamento, verifica-se uma apreciável fraturação das partículas rochosas, pelo que as deformações volumétricas são normalmente de compressão.

Pelo aumento das solicitações aplicadas aos materiais de enrocamento, verifica-se uma transferência dos mecanismos intrínsecos do comportamento tensão-deformação. Em uma fase inicial, as propriedades reológicas dependem, sobretudo, da mobilidade relativa das partículas, enquanto que em uma fase final é condicionada principalmente pelo fraturamento das partículas rochosas, Veiga Pinto (1983).

\subsubsection{Fatores que influenciam a deformabilidade}

Vários fatores podem afetar direta ou indiretamente o comportamento de compressibilidade do enrocamento. Materon (1983) relaciona alguns desses fatores que são representados por: mineralogia, granulometria, índice de vazios, formas das partículas, resistência ao fraturamento dos grãos, tamanho, textura, teor de água e velocidade de carregamento.

Em um estudo de laboratório de Veiga Pinto (1979), houve a oportunidade de analisar as características de tensão-deformação dos materiais de enrocamento e, em particular, os diversos fatores que mais influenciam o comportamento mecânico desses materiais. O esquema ilustrativo a seguir cita esses fatores. 


\begin{tabular}{|c|c|c|}
\hline 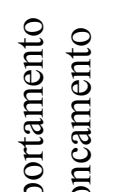 & $\begin{array}{l}\text { Tipo de elementos } \\
\text { rochosos }\end{array}$ & $\begin{array}{l}\text { Resistência ao esmagamento } \\
\text { Forma das partículas } \\
\text { Tipo litológico } \\
\text { Fricção entre partículas }\end{array}$ \\
\hline 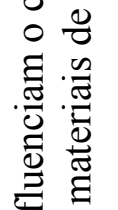 & $\begin{array}{l}\text { Estrutura do meio } \\
\text { granular }\end{array}$ & $\begin{array}{l}\text { Estado de compacidade } \\
\text { Dispersão granulométrica } \\
\text { Teor em água } \\
\text { Inclusão de finos }\end{array}$ \\
\hline 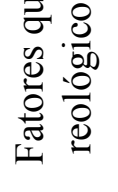 & $\begin{array}{l}\text { Modalidade de } \\
\text { ensaio }\end{array}$ & $\begin{array}{l}\text { Trajetória de tensões } \\
\text { Tensão-deformação controlada } \\
\text { Revestimento da amostra } \\
\text { Velocidade de carregamento }\end{array}$ \\
\hline
\end{tabular}

A inter-relação desses fatores na natureza é complexa e de difícil interpretação. Não existem regras fixas que permitam generalizar as recomendações para melhorar as propriedades do enrocamento, já que as características naturais do mesmo se alteram com a presença simultânea dos diferentes fatores mencionados. A seguir, são descritas as observações de alguns fatores que podem afetar a deformabilidade do enrocamento.

\subsubsection{Mineralogia}

A mineralogia afeta as propriedades de engenharia do material granular por controlar as propriedades físicas de cada partícula de rocha. Ensaios de atrito superficiais realizados por Horn \& Deere (1962), em diferentes minerais, mostram que sob as mesmas condições de ensaios, diferentes minerais apresentam diferentes coeficientes de atrito, e minerais de mesmo tipo, embora de diferentes origens, têm a mesma característica de atrito.

$\mathrm{O}$ atrito entre os grãos não somente interfere na resistência do material, mas também na compressibilidade, de forma que o rearranjo entre partículas depende do atrito entre elas. 


\subsubsection{2 Índice de vazios e densidade relativa}

Um fator que influencia a resistência e deformabilidade do material granular é o índice de vazios. A compressibilidade para amostras inicialmente fofas é bem maior que para amostras densas, Terzaghi \& Peck (1948).

Fumagalli (1969) utilizou o índice de vazios como parâmetro de representatividade. Porém, ao serem ensaiadas duas amostras do mesmo material com distribuições granulométricas paralelas e iguais índice de vazios inicial, estas não apresentam comportamento semelhante, Neves (2002). Becker et al. (1972) comprovou esse fato ao analisar resultados de compressão triaxial de amostras ensaiadas com o mesmo índice de vazios e outras com a mesma densidade relativa.

Santos et al. (2005), através de ensaio de compressão unidimensional, mostra que a densidade relativa (Dr) é o parâmetro mais representativo do efeito de escala. A Figura 11 apresenta resultados de duas granulometria diferentes $\left(\varnothing_{\text {máx. }} 3\right.$ " e 1") com pesos específicos praticamente iguais, ou seja, com mesmo índice de vazios. Pode-se notar a diferença significativa do comportamento de deformação das duas curvas. Esse fato pode ser explicado pelas diferentes densidades relativas obtidas nos ensaios de compactação. 


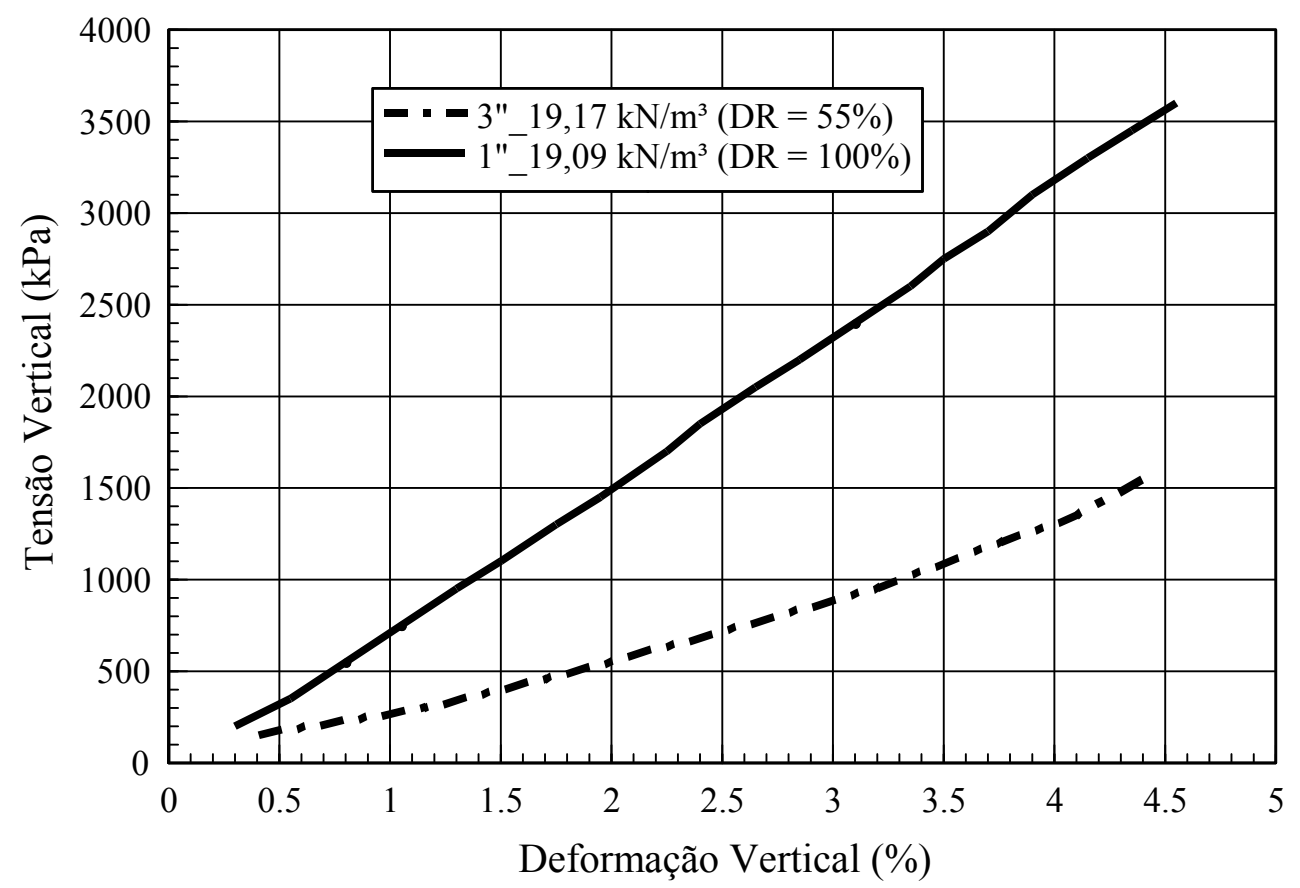

Figura 11. Comportamento de deformação unidirecional para amostras com mesmo índice de vazios, porem diferentes granulometria e densidade relativa, Santos et al. (2005)

\subsubsection{Granulometria}

Enrocamentos bem graduados permitem, para a mesma energia de compactação, produzir maciços mais densos, menos deformáveis e, conseqüentemente, menos suscetíveis ao fraturamento interno dos blocos, que enrocamentos do mesmo material de granulometria uniforme, Materon (1983).

Marsal (1973) observou que um material bem graduado, por apresentar partículas de diâmetros bastante variados, possui, por essa razão, um número de contatos entre os grãos bem maiores do que um material uniforme, uma vez que as partículas menores tendem a ocupar os vazios deixados entre as partículas maiores. Portanto, um maior número de contatos resulta em maior distribuição das tensões de contato e menores forças intergranulares, reduzindo, assim, a quebra de contatos e o rearranjo entre partículas. 
Para se obter um enrocamento com baixa compressibilidade, é necessário minorar as forças intergranulares e reduzir o rearranjo das partículas, através do alcance de altas densidades. Isso pode ser conseguido utilizando-se enrocamentos, cuja curva granulométrica seja bem distribuída, para se obter o mínimo de vazios e, conseqüentemente, um número máximo de contatos.

\subsubsection{Forma de partículas}

Segundo Penman (1969), quando a forma da partícula apresenta cantos mais arredondados, a compressibilidade do enrocamento é significativamente menor. Tal comportamento se dá devido ao maior índice de vazios apresentados por aterros de enrocamentos de partículas angulares, quando comparados com aqueles apresentados em enrocamentos compostos por partículas arredondadas.

O índice de vazios alto resulta em maiores forças de contatos, que geram altas pressões nos grãos, resultantes da pequena área de contato entre partículas pontiagudas ou angulares. Essa pressão se traduz por uma maior quebra nos pontos de contato entre as partículas, emprestando à massa uma compressibilidade acentuada. Em adição, partículas arredondadas, por não apresentarem formas salientes, geralmente dão origem a aterros pouco compressíveis, devido ao menor fraturamento dos contatos como, por exemplo, os cascalhos e seixos utilizados em algumas barragens de enrocamento e que apresentaram altos valores de módulos de deformabilidade construtivos.

\subsubsection{Dimensão e resistência dos grãos}

De acordo com Marsal (1973), partículas de enrocamentos se diferenciam umas das outras quanto à natureza dos minerais que as compõem e quanto às propriedades mecânicas. As partículas de rocha são friáveis, e têm uma resistência à compressão de quatro a cinco vezes maiores que a resistência à tração. As partículas freqüentemente possuem fissuras e vazios e podem estar alteradas. Daí resulta que a quebra de partículas é um processo complexo, em vista da natureza dos materiais. Além disso, o caráter estatístico das forças de contato em uma geometria estrutural 
irregular das partículas e a variação das áreas de contato entre as mesmas torna impossível a previsão do estado de tensões interno da partícula.

Quanto à influência do tamanho dos grãos, as forças de contato $P$ entre partículas individuais exibem uma distribuição aproximadamente normal. De acordo com Neves \& Veiga Pinto (1977) a força média é dada pela Equação 11:

$$
P=k \cdot D^{b}
$$

sendo $D$ o diâmetro nominal das partículas e $k$ e $b$ constantes determináveis experimentalmente.

A força que provoca o esmagamento de uma partícula, $P_{a}$, obedece, segundo Marsal (1969) a uma lei do mesmo tipo. O valor médio dessas forças é dado pela Equação 12:

$$
P_{a}=\eta \cdot D^{\beta}
$$

onde $\eta$ e $\beta$ são constantes. Exprimindo as forças e diâmetro nas Equações 11 e 12, nas mesmas unidades, verifica-se que $\beta$ é menor que $b$, pelo fato de que a fraturação aumenta com o diâmetro da partícula, o que é ilustrado na Figura 12 pelo aumento da área de sobreposição das curvas de distribuição de $P$ e $P_{a}$, quando aumenta a dimensão da partícula. 

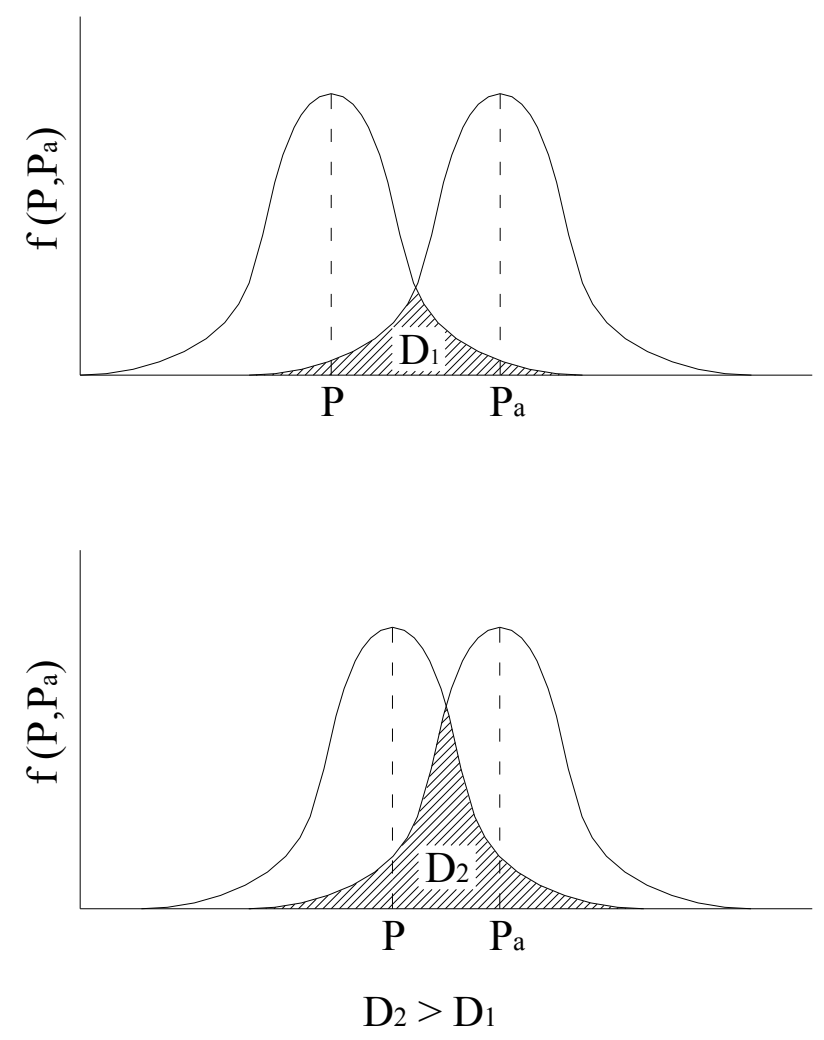

Figura 12. Distribuição normal das forças de contato, Marsal (1969).

Esse comportamento foi verificado em ensaios laboratoriais de enrocamento. Não se pode deixar de ter em conta que a quebra de um bloco de rocha dá naturalmente origem a partículas mais resistentes que o bloco de rocha que os originou.

Marsal (1973) através de um modelo matemático e estatístico para a distribuição das forças de contato concluiu que em uma aproximação de cálculo para diferentes materiais, assumindo uma pressão constante em uma determinada área, obtêm-se as seguintes relações das forças de contato médias:

$$
P_{\text {enrocamento }}=10^{3} \times P_{\text {pedregulho }}=10^{6} \times P_{\text {areia média }}
$$

Dessa forma, verifica-se que baixas forças de contato podem causar quebra de blocos ou partículas de enrocamento ao passo que para quebra de partículas de areia é necessário que haja um nível de tensões aplicadas muito mais alto. 


\subsubsection{Nivel de tensão}

Sob alta tensão de confinamento, a compressão dos materiais granulares é acompanhada por uma quantidade substancial de quebra das partículas, enquanto que sob baixas tensões, os deslocamentos intergranulares predominam através de um rearranjo estrutural.

Marachi et al. 1969, ao realizarem ensaios triaxiais sob diferentes tensões confinantes e diferentes tamanhos de amostras constataram que as características de resistência e deformação foram afetadas pelas tensões de confinamento utilizadas nos ensaios. As deformações volumétrica e axial na ruptura aumentam com o acréscimo das tensões confinantes Figura 13 e o ângulo de atrito interno tende a decrescer com o confinamento.

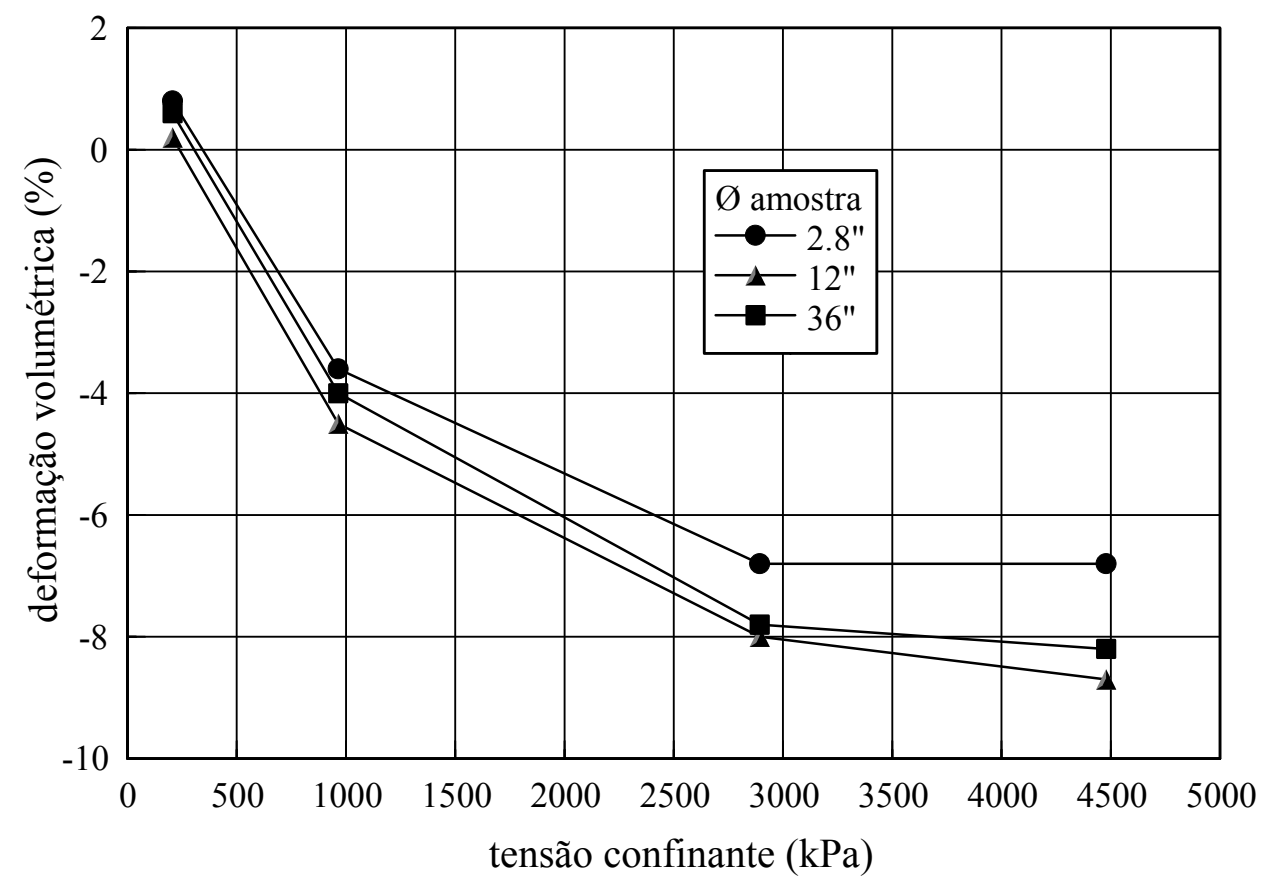

Figura 13. Deformação volumétrica na ruptura para diferentes níveis de tensões em granulometrias distintas de basalto, Marachi et al. (1969). 
Verifica-se que o aumento da deformação volumétrica é mais pronunciado para as variações sob baixos níveis de confinamento. Para altas tensões de confinamento a variação da deformação volumétrica pouco se altera.

\subsubsection{Teor de umidade}

Como é de nosso conhecimento, através de estudos de vários autores como Marsal (1973), Nobari \& Duncan (1972) entre outros, o enrocamento sofre colapso quando a tensão efetiva constante exibe deformação relativamente rápida em resultado de alteração do seu teor em água. A maior facilidade dos grãos se romperem e, principalmente, ocorrerem esmagamentos nos cantos dos fragmentos no estado úmido, é pelo fato de que, nestas condições, pressões neutras surgem no interior do grão, diminuindo sua resistência ao fraturamento. Além disso, a capilaridade pode ter efeito nas microfissuras de um fragmento quando em estado seco, aumentando a resistência à fraturação.

Através de um estudo experimental de Oldecop \& Alonso (2001), verificou-se que a fraturação das partículas rochosas e a propagação da fratura no grão são mecanismos básicos subjacentes ao comportamento do material, e tais mecanismos são controlados pela umidade relativa do ar que preenche os vazios do enrocamento. Verificou-se que as deformações por colapso obtidas em meio saturado eram semelhantes àquelas obtidas com umidade relativa do ar próxima a $100 \%$.

É natural que estruturas de enrocamento fiquem com baixo índice de vazios com abundante utilização de água durante a sua compactação, para que as deformações por colapso possam ser significativas. No entanto, a variação da tensão e a alternância da presença de água no maciço podem dar origem a novas deformações por colapso.

\subsection{Comportamento do maciço de enrocamento em BEFC}

As BEFC apresentam duas fases distintas de solicitações: inicialmente ela é submetida ao carregamento próprio correspondente ao peso das camadas sobrejacentes de enrocamento e, 
depois, com o enchimento do reservatório, ao carregamento hidrostático transmitido pela laje de concreto.

As tensões inicialmente produzidas pelo carregamento próprio ficam difíceis de serem avaliadas, já que o alteamento do maciço se processa em diferentes formas, ou seja, obedecendo às condições construtivas em que algumas regiões independem de outras para serem lançadas. Já na fase de enchimento do reservatório, toda a carga hidrostática é transmitida ao maciço de enrocamento e esta é responsável pelas deflexões da face.

No final do período construtivo, as deformações no centro da barragem são principalmente verticais, devido ao estado de compressão confinada. Próximo aos espaldares, as deformações iniciais são principalmente verticais, porém, com a progressão do alteamento do aterro, o incremento do movimento lateral torna-se significante.

Mori (1999) cita que os contornos da seção deformada no final de construção indicam um abaulamento aproximadamente simétrico das linhas externas de montante e de jusante no topo, e, algumas vezes, um estufamento ou inchamento também aproximadamente simétrico na parte inferior da seção, típicas de um maciço compressível. Já na fase de enchimento do reservatório, apenas a linha externa de montante se desloca para a jusante. Em geral, o contorno do talude de montante se desloca para uma posição mais a jusante do que a linha de projeto, desde seu pé até a crista (Figura 14). 


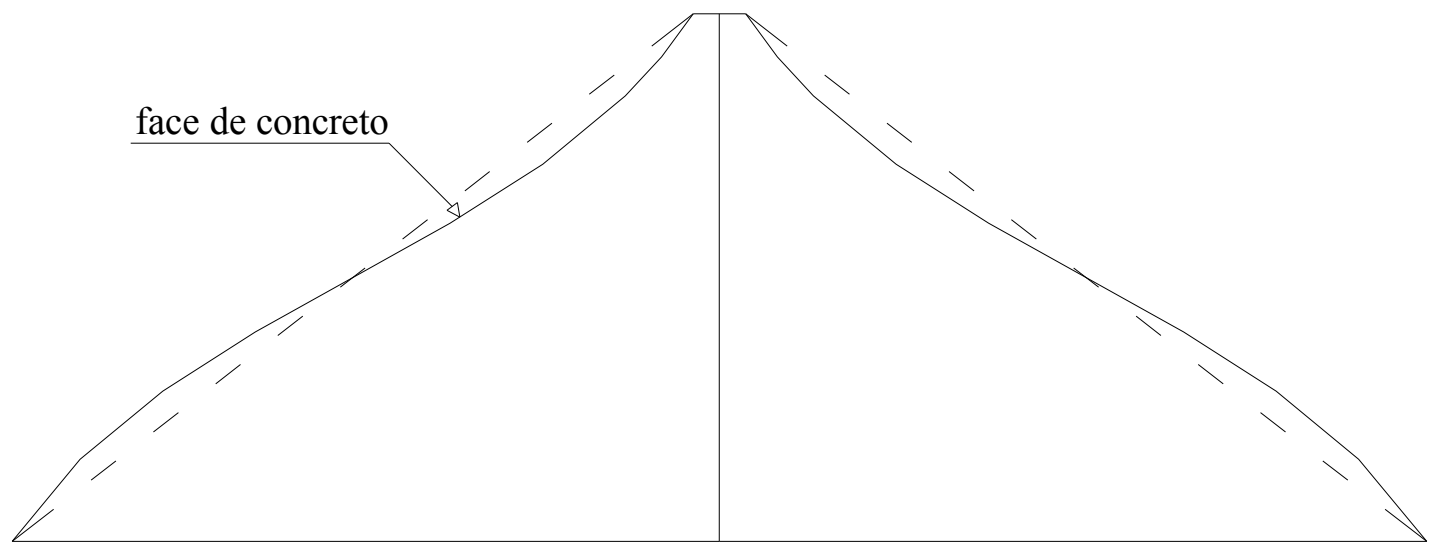

Final de Construção

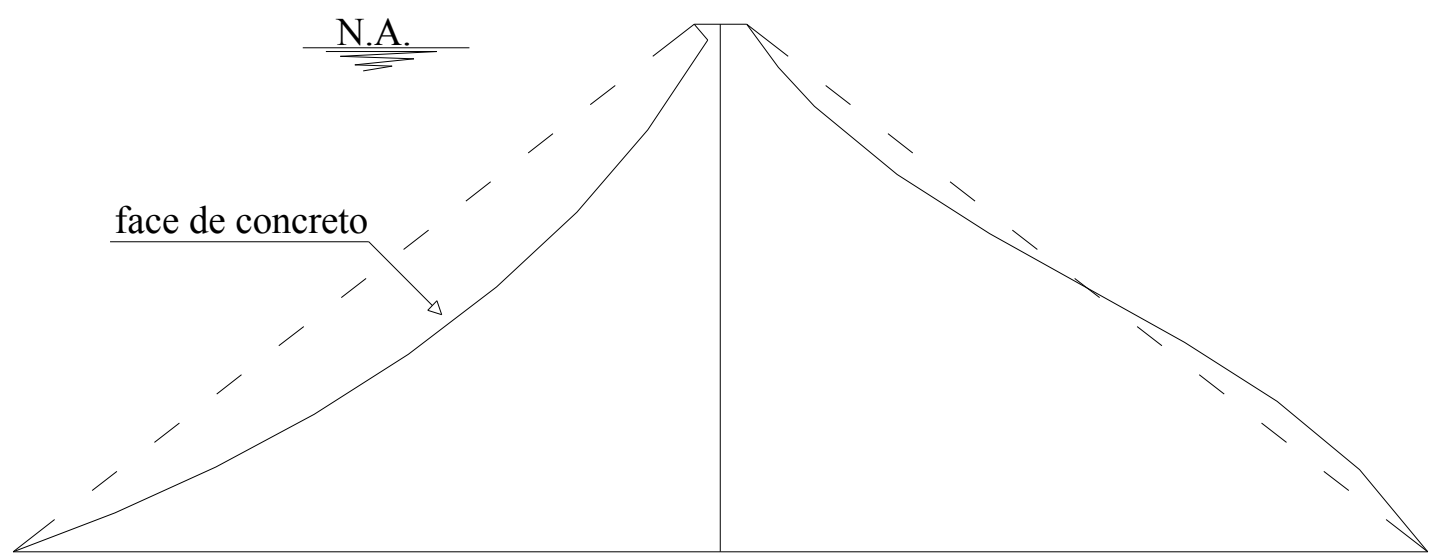

Enchimento do Reservatório

\section{LEGENDA}

- _ _ - Seção de projeto

OBS. : Desenho sem escala Seção após proceder as deformações

Figura 14. Abaulamento da seção do maciço ao final de construção e conseqüente deflexão da face de montante com o enchimento do reservatório, Mori (1999).

O maciço compactado de uma BEFC é uma estrutura deformável com características clássicas de material plástico, com deformações específicas muito pequenas de recuperação em descarregamento dos esforços cisalhantes originalmente aplicados. Veiga Pinto (1983) mostra que o comportamento tensão-deformação de um enrocamento é totalmente distinto em condições de carregamento e de descarregamento de tensões cisalhantes, sendo que o enrocamento é muito 
mais rígido no descarregamento. O módulo de compressibilidade no descarregamento é da ordem de 5 a 6 vezes maior que o módulo de carregamento.

Analisando o estado de tensões em três pontos distintos no interior do maciço de enrocamento de uma BEFC, pode-se dizer que em um ponto próximo à face de concreto, no período anterior ao enchimento, possui baixas tensões de construção ao contrário do estado de tensão em um ponto mais ao interior do maciço. Com o aumento das pressões hidrostáticas, a parte superficial, submetida a baixas tensões de construção, passa a um estado novo de compressão e a se deformar muito mais, enquanto que a parte inferior, submetida a maiores tensões confinamento, continua descarregando a tensão cisalhante e, portanto, sofre menores deformações (Figura 15). Em outras palavras, a parte superficial do enrocamento, incluindo as zonas de transição fina e grossa sob a laje, é a responsável praticamente pela totalidade das deformações da barragem com o enchimento do reservatório, Mori (1999).
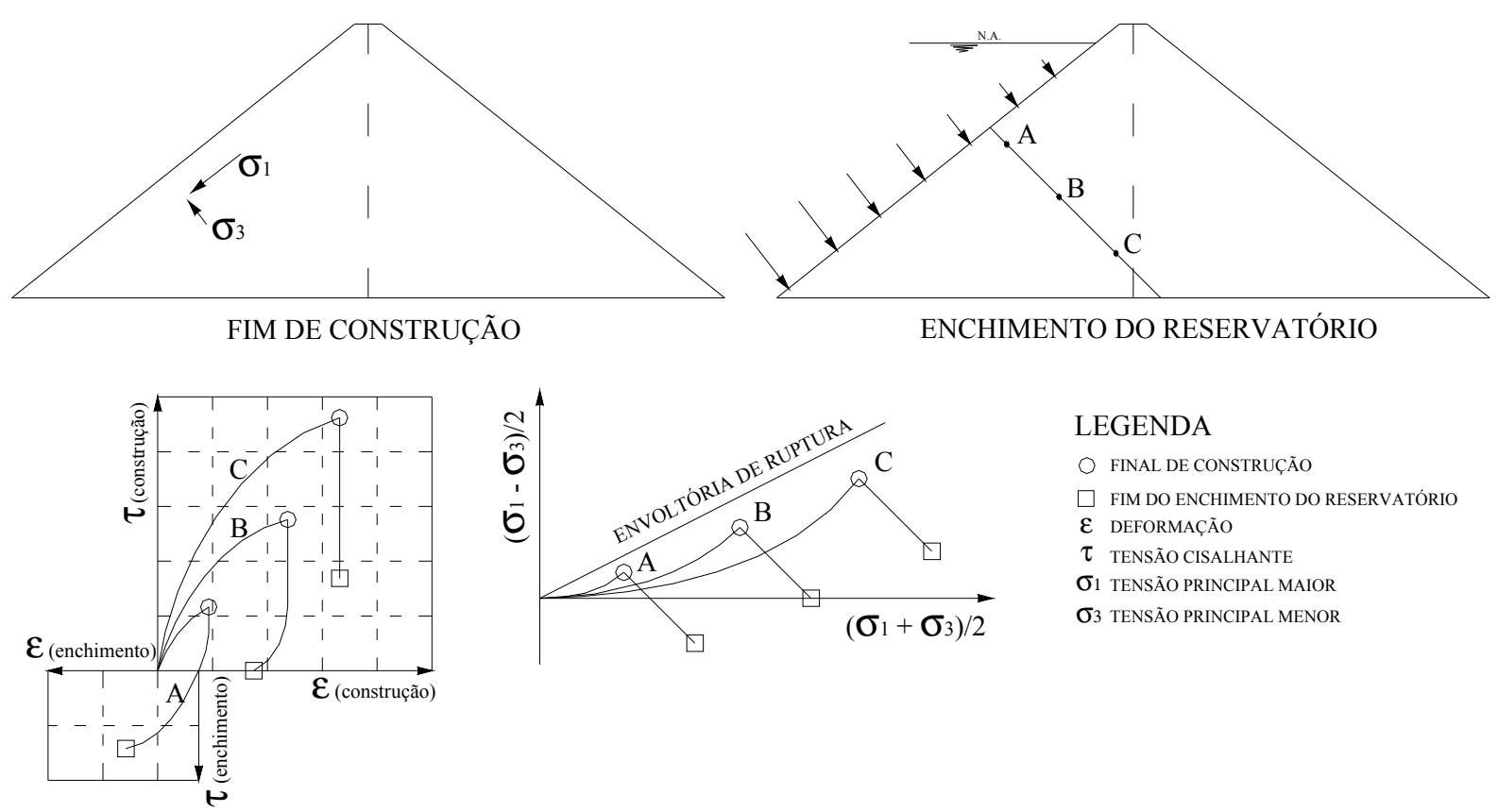

LEGENDA

FINAL DE CONSTRUÇ̃̃o

$\square$ FIM DO ENCHIMENTO DO RESERVATÓRIO

$\varepsilon$ DEFORMAÇ̃̃o

$\tau$ TENSÃo CISALHANTE

$\sigma_{1}$ TENSÃO PRINCIPAL MAIOR

$\sigma_{3}$ TENSÃO PRINCIPAL MENOR

Figura 15. Esquema ilustrativo do processo de carregamento, para a fase de enchimento do reservatório, Mori (1999). 
Várias publicações sobre estimativa da deformação da laje da face indicam que quase sempre há uma diferença entre os deslocamentos previstos em métodos de elementos finitos e os deslocamentos observados em campo. Até pouco mais da metade da laje há uma coincidência bastante razoável entre as previsões e os valores medidos, mas a partir desse ponto e até a crista, os deslocamentos medidos são sempre maiores que os previstos. A relação entre o deslocamento da laje na crista e os deslocamentos ao longo da laje no período pós-enchimento tem sido quase sempre maior ou próximo de um.

É evidente que o enrocamento de montante sofre um carregamento em valor e direção, muito diferente do enrocamento a jusante. Há regiões de recompressão, mas com mudança ou não na direção da resultante. Além do mais um enrocamento é um material que, para baixas tensões pode ter um comportamento "elástico-linear", mas que no descarregamento é muito pouco elástico, Cruz (2005).

Portanto, não é válido calcular os deslocamentos no maciço com somente um único valor de módulo. A deformabilidade do enrocamento é diferente para os diferentes estados e trajetórias de tensões.

\subsubsection{Rotação do plano principal maior}

O estado de tensão varia bastante de uma fase para outra e os deslocamentos horizontais na fase de enchimento são majorados principalmente na região próxima ao talude de montante se comparados com os deslocamentos horizontais da fase de construção. Tal comportamento indica que há uma rotação das tensões principais devidas ao carregamento hidrostático e essa rotação é mais pronunciada na região próxima ao parâmetro inferior de montante, Basso \& Cruz (2006). A Figura 16 ilustra o comportamento de rotação das tensões principais no decorrer do enchimento do reservatório. 


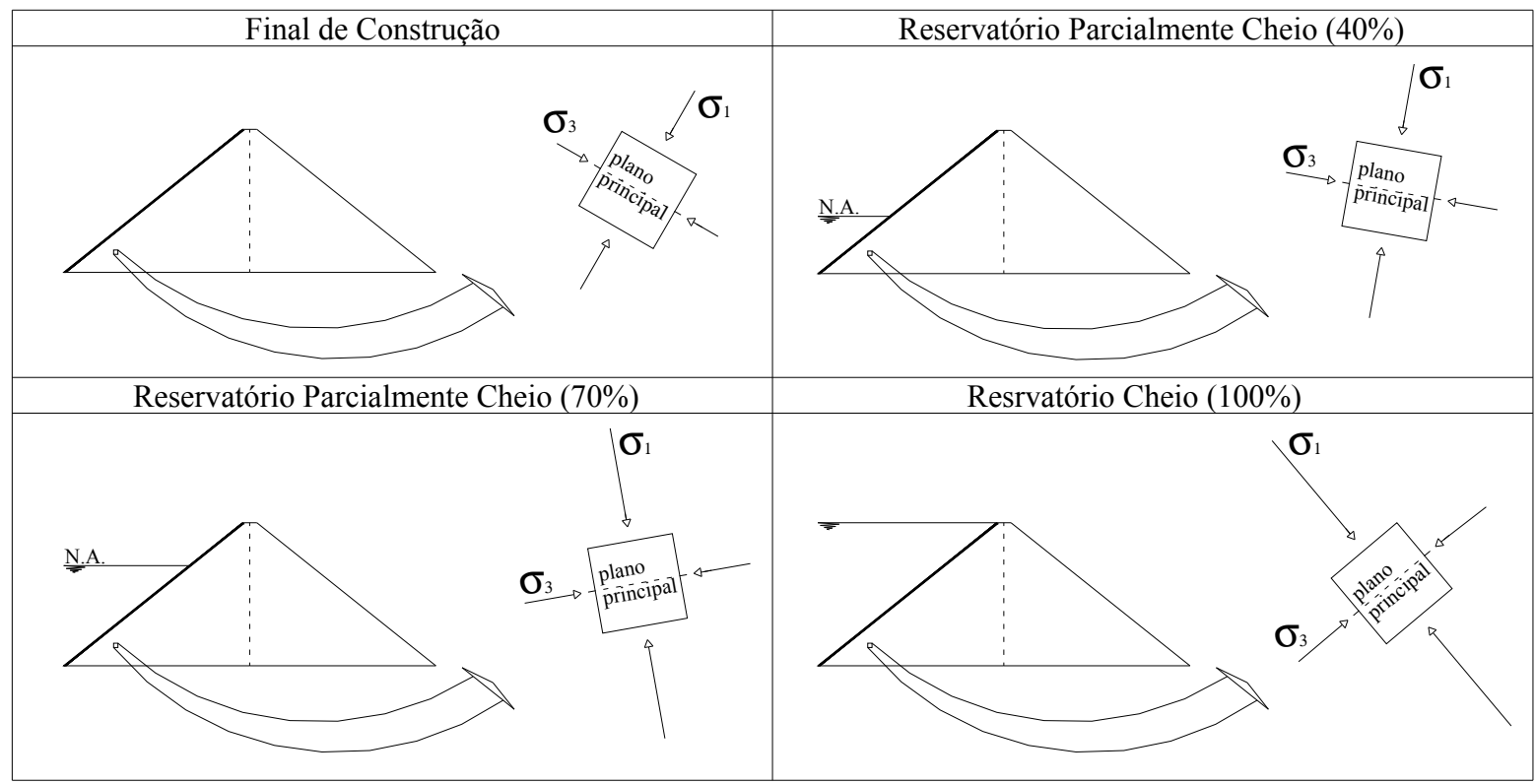

Figura 16. Fenômeno de rotação das tensões principais, na região de montante, devido ao enchimento do reservatório.

No entanto, não há clareza de como as deformações se processam quando tal fenômeno de rotação ocorre no maciço de enrocamento. Sabe-se que há um confinamento do material durante o carregamento, porém as alterações das tensões principais ocorrem simultaneamente com a rotação do plano principal maior. As trajetórias de tensões desenvolvidas durante o carregamento hidrostático são distintas para as diferentes zonas do maciço. 


\section{LEIS CONSTITUTIVAS E PARÂMETROS DE ANÁLISE}

$\mathrm{Na}$ interpretação fenomenológica de ensaios laboratoriais, analisa-se a variação da geometria do corpo de prova resultante da aplicação de uma determinada solicitação. As relações desse tipo designam-se por equações constitutivas. Essas equações são agrupadas ou classificadas de acordo com o grau de aproximação do ajustamento teórico ao real, compondo as leis constitutivas.

Em face da dificuldade de aplicação de leis constitutivas de grande generalidade, é comum recorrer-se a métodos mais simplificados. Em vez da elaboração de modelos matemáticos muito sofisticados, é preferível investir no conhecimento de modelos mais simples, cujas limitações na aplicação são conhecidas e em que se atendeu aos fatores que influenciam realmente o seu comportamento fenomenológico, Veiga Pinto (1983).

A determinação experimental dos valores dos parâmetros das equações constitutivas é dos fatores que mais influenciam a qualidade das previsões. Desse modo, este trabalho é uma tentativa de determinar os referidos valores de parâmetros, desenvolvendo equipamento e conduzindo ensaios laboratoriais.

Segundo Veiga Pinto (1983), é aceitável que os ensaios de compressão unidimensional sejam mais representativos quando se analisa a zona central de uma barragem, onde o confinamento é acentuado. Para as regiões próximas aos espaldares, os ensaios triaxiais representam melhor as condições de carregamento (trajetória de tensões), já que nessas regiões acentuam-se os deslocamentos horizontais.

Uma forma de estabelecer correlação às práticas usuais de previsão de comportamento de barragens de enrocamento é analisar a influência do estado de tensão na rigidez do material quando um corpo de prova é submetido a carregamentos em diferentes direções. Baseando-se no método de análise exposto no item 2.3, alguns ensaios tri-triaxiais foram executados seguindo diferentes trajetórias de tensões com diferentes níveis de tensões, objetivando avaliar os módulos de deformabilidade, mesmo que estes sejam aplicados a modelos elásticos lineares, que de uma forma geral podem conduzir a resultados satisfatórios. 
Os resultados do estudo de laboratório realizados serão expostos e analisados posteriormente. As análises dizem respeito à determinação de parâmetro de deformabilidade e também de resistência, objetivando uma melhor interpretação do comportamento fenomenológico do maciço de enrocamento.

Em seguida, são abordados, sucintamente, os parâmetros básicos a serem obtidos através de ensaios laboratoriais e alguns conceitos dos modelos mais comuns utilizados na mecânica dos solos: elasticidade linear, elasticidade variável e elastoplásticos.

\subsection{Módulo de elasticidade}

Um dos tipos de ensaio em que é possível avaliar a rigidez do material é o ensaio triaxial. Através de um carregamento tridimensional (Figura 17) é possível obter alguns parâmetros.

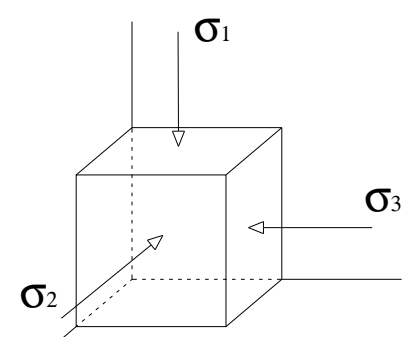

Figura 17. Obtenção de parâmetros de compressibilidade através de ensaios laboratoriais, Lambe (1969).

Para pequenas deformações, pode-se recorrer à teoria da elasticidade e calcular as deformações com as Equações 13 e 14.

$$
E=\frac{\sigma_{1}-\sigma_{3}}{\varepsilon_{1}}
$$




$$
\frac{\Delta V}{V}=\frac{1}{E}\left[(1-2 v)\left(\sigma_{1}+\sigma_{2}+\sigma_{3}\right)\right]
$$

\subsection{Modelos Elásticos Lineares}

Os modelos elásticos lineares são os mais simples e já foram amplamente divulgados, tendo grande aplicação no cálculo estrutural em geral. Dentre eles o isotrópico se destaca pela sua simplicidade utilizando somente dois parâmetros elásticos (módulo de Young e coeficiente de Poisson).

Modelos anisotrópicos, isto é, que possuam módulos de Young e coeficiente de Poisson diferentes em diferentes direções, também não apresentam problemas, a menos da determinação dos parâmetros.

Veiga Pinto (1983), Covarrubias (1969) e Boughton (1970) mencionaram que os modelos elásticos lineares apresentam uma desvantagem quando simulam regiões de tração em barragens de aterros. Estas já não se verificam quando se recorrem a modelos de elasticidade variável.

\subsection{Modelos de Elasticidade Variável}

Tais modelos representam um dos mais usados porque são capazes de reproduzir de forma satisfatória os comportamentos dos materiais granulares. Além disso, são bem mais simples que os modelos elastoplásticos.

Esses modelos estabelecem leis empíricas que devem simular a curva tensão-deformação dos materiais, o mais aproximadamente possível. Cabe mencionar que o modelo de elasticidade variável não é, como o nome sugere, elástico, pois possui módulos de carga e descarga diferentes, o que significa que incorporam uma parcela de deformações não recuperáveis (plásticas). 
Além do modelo hiperbólico, existem os modelos EC-K $\mathrm{K}_{\mathrm{o}}$ e K-G que são apresentados por Veiga Pinto (1983).

Tais modelos de elasticidade variável são diferenciais, já que relacionam incrementos de tensão com incrementos de deformação e, desse modo, consideram módulos tangentes de valor constantes nos sucessivos intervalos (diferencial da curva tensão-deformação no ponto médio do incremento). Outro método de quantificar os módulos em função de um dado estado de tensão é através de uma via interativa (módulos secantes), por aproximações sucessivas. Os métodos estão meramente representados na Figura 18.

MÓDULO TANGENTE

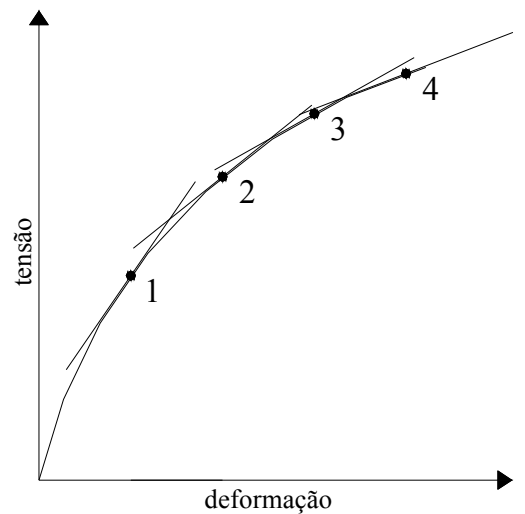

MÓDULO SECANTE

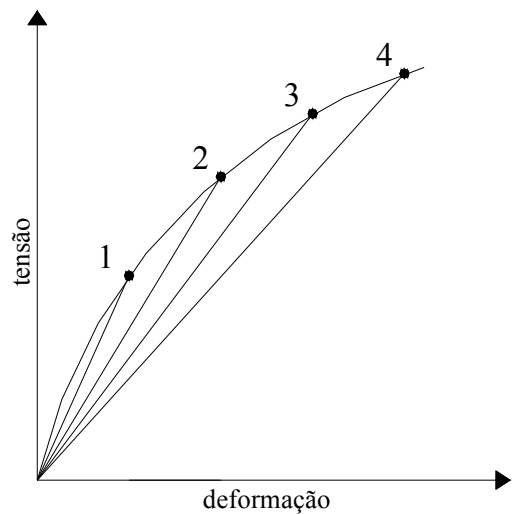

Figura 18. Métodos de obtenção de módulos de deformabilidade.

Das várias leis tensão-deformação que têm sido desenvolvidas, usando a técnica dos módulos tangentes, a lei hiperbólica se sobressai, pois é a mais aplicada para a maioria dos casos de análise de barragens de enrocamento.

Este modelo é atribuído a Kondner (1963), o qual propôs que uma curva "tensão - deformação" deveria ser aproximada a uma hipérbole (Equação 19):

$$
\sigma_{1}-\sigma_{3}=\frac{\varepsilon_{1}}{a+b \varepsilon_{1}}
$$


O modelo hiperbólico de Duncan e Chang (1970) pode ser exemplo de método de cálculo que utiliza resultados de ensaios triaxiais e leva em consideração a variação dos parâmetros de deformabilidade e resistência em relação ao nível de confinamento. Tais parâmetros são representados por módulos de Young inicial $E_{i}$, tangente $E_{t}$ e de descarregamento $E_{D R}$, coeficiente de Poisson $v$, Coeficiente de Ruptura $R_{f}$ e ângulo de atrito $\varphi$. Detalhes desse modelo e dos parâmetros necessários encontram-se no Apêndice A.

\subsection{Modelos Elastoplásticos}

A principal diferença entre os modelos de elasticidade variável e os elastoplásticos é que neste se sabe, a cada instante de aplicação de cargas, quais as deformações plásticas, ao contrário daqueles, em que as deformações não recuperáveis somente serão conhecidas quando do alívio de cargas. Além disso, os modelos elastoplásticos simulam bem o aumento de rigidez durante o descarregamento, reproduzem diferentes trajetórias de tensões, e absorvem as deformações plásticas a que o material foi submetido.

O incremento de deformação é obtido pela soma das deformações plásticas (Equação 20):

$$
\Delta|\mathcal{\varepsilon}|=\Delta|\varepsilon|_{e}+\Delta|\varepsilon|_{p}
$$

As deformações plásticas são calculadas por uma expressão do tipo (Equação 21):

$$
\Delta|\varepsilon|_{p}=\lambda \frac{\delta Q}{\delta|\sigma|}
$$

sendo $Q$ o potencial plástico e $\lambda$ um fator de proporcionalidade relacionado ao trabalho produzido pelas deformações plásticas.

Trata-se de um modelo complexo, com um grande número de parâmetros e cujo emprego requer uma especialização. Embora adequados para análise de barragens, em qualquer fase de carregamento, têm sido de uso limitado e nem sempre têm resultados em previsões melhores do que as dos modelos de elasticidade variável. 


\section{ESTUDO DE TENSÕES}

\subsection{Simulações realizadas}

As simulações foram realizadas objetivando obter o nível e o estado de tensões em alguns pontos de um maciço de BEFC na fase de final de construção (carregamento próprio) e, conseqüentemente, a obtenção das variações das tensões nos mesmos pontos durante o enchimento, caracterizando, assim, a evolução das tensões para, posteriormente, avaliar as condições de carregamento desenvolvidas nos diferentes pontos do maciço.

Para essas simulações numéricas, foi utilizado o programa de elementos finitos SIGMA-W da Geo-Slope International. A malha para análise foi elaborada para uma seção hipotética de uma BEFC de $200 \mathrm{~m}$ de altura, com talude 1:1,3 em montante e jusante, considerando a fundação indeformável e com os vínculos indeslocáveis para as duas direções.

O modelo de comportamento do material considerado nessa fase de simulações foi o elásticolinear, pois não se dispunha de dados, seja de campo, seja de laboratório, sobre as variações da rigidez do maciço quando as tensões seguem as mais diversas trajetórias. Caso contrário seria possível utilizar modelos mais complexos que necessitariam de um número maior de parâmetros de entrada.

As análises foram realizadas considerando módulos de deformabilidade do maciço zoneados com valores decrescentes de montante para jusante de $80,60,40$ e $20 \mathrm{MPa}$, sendo que o primeiro se refere à zona de transição $2 \mathrm{~B}$ com $4 \mathrm{~m}$ de espessura e os demais à zona 3 , conforme ilustra a Figura 19. Para a laje de face, considerou-se a espessura de $1 \mathrm{~m}$ e rigidez equivalente ao concreto de resistência $f_{c k}$ igual a $18 \mathrm{MPa}$, resultando em um módulo de deformabilidade de $20000 \mathrm{MPa}$, conforme NBR-6118/2000. Além disso, admitiu-se que o enrocamento compactado possui peso específico de $20 \mathrm{kN} / \mathrm{m}^{3}$, coeficiente de Poisson de 0,3 e coeficiente de empuxo de 0,4. Esses parâmetros foram adotados com base na literatura existente, obedecendo à variação da rigidez no 
maciço em função da compactação diferenciada das camadas e do tipo de granulometria adotada nas diferentes zonas do maciço.

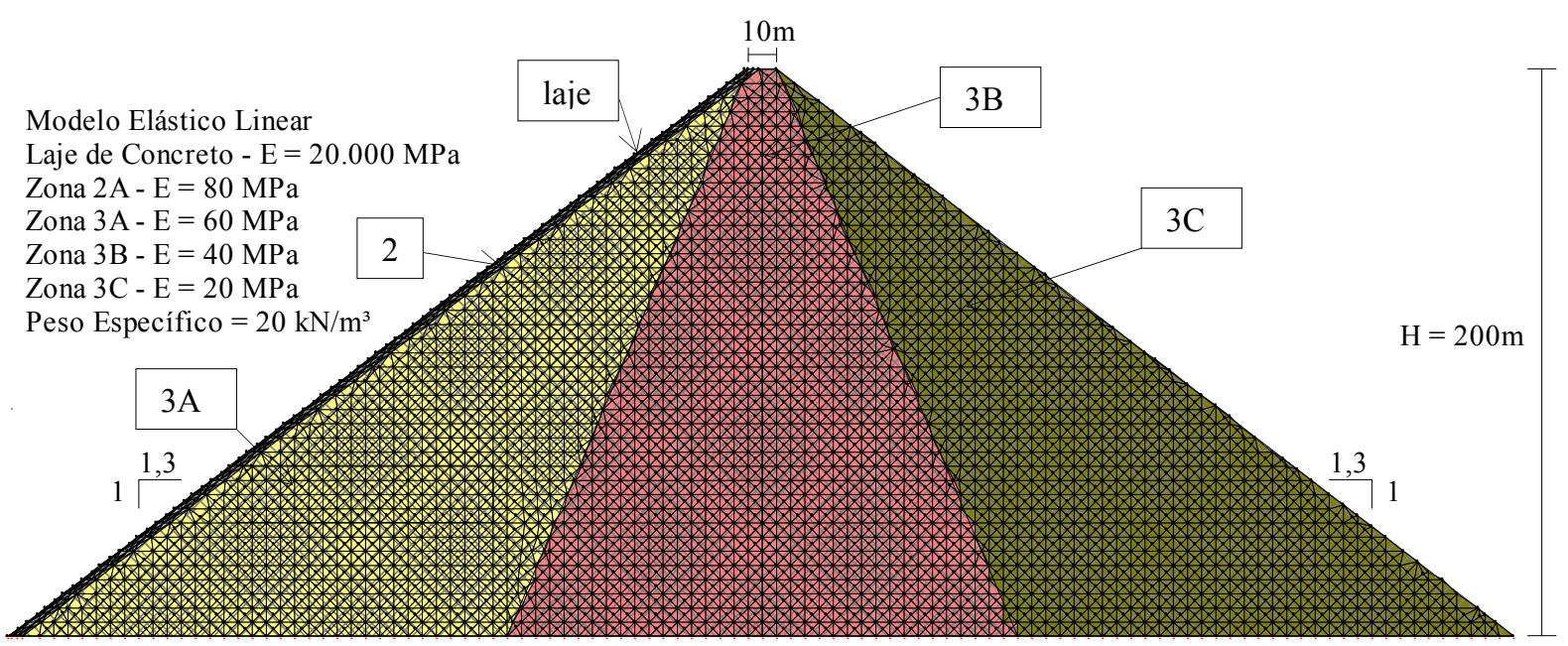

Figura 19. Malha de elementos finitos utilizada para simulação na condição de zoneamento de diferentes módulos.

As fases de construção do aterro e enchimento do reservatório foram simuladas com incrementos de carga de $20 \%$, ou seja, carregamentos correspondentes à altura de camadas de $40 \mathrm{~m}$ para a fase construtiva e carga hidrostática de $40 \mathrm{mca}$ durante o enchimento, até a cota da crista.

Os pontos analisados foram distribuídos em três linhas perpendiculares à face de montante (linha $m, n$ e $o$ ) e igualmente espaçadas. Cada linha contém 4 pontos também igualmente espaçados. A intenção é analisar as tensões normais geradas em planos paralelos e perpendiculares à face no interior do maciço. Isso porque as previsões e as medidas de deflexão da laje são feitas através de linhas normais à face de montante, como citado nos subitens 2.3 .2 e 2.4 deste trabalho. Além disso, também foram determinados valores de tensões verticais e horizontais em cada ponto.

A locação dos pontos analisados $(\mathrm{x}, \mathrm{y})$ em relação ao ponto $0(0,0)$ e as linhas normais à face estão representados na Figura 20. Na mesma figura, são apresentados os vetores das tensões principais maiores $\sigma_{l}$ obtidos na simulação numérica para as condições de final de construção do aterro e final de enchimento do reservatório. 


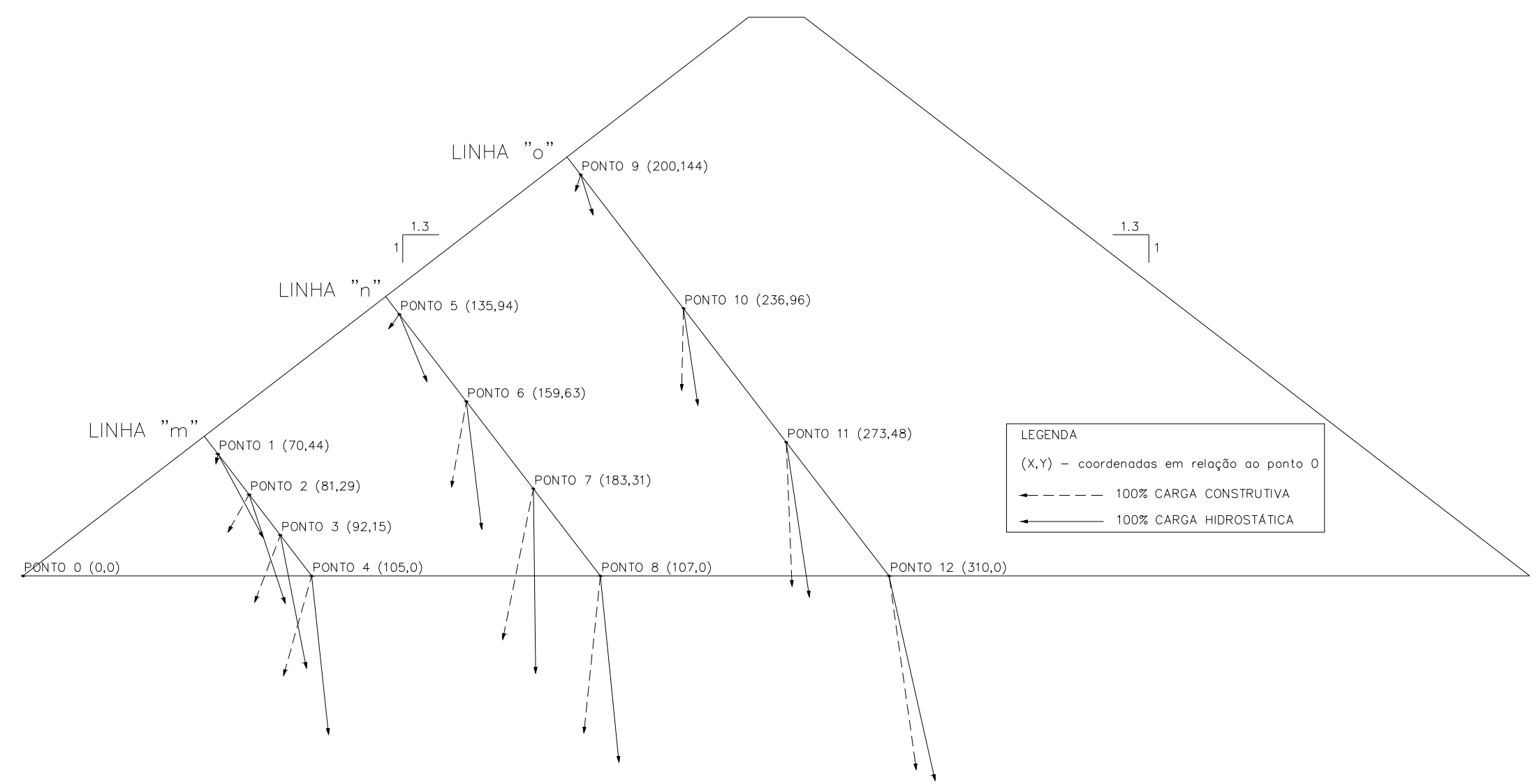

Figura 20. Esquema representativo dos pontos analisados e resultados dos vetores de tensões principais maiores $\sigma_{l}$ obtidos na simulação numérica. 
Na Tabela 2 encontram-se os resultados obtidos da simulação numérica para cada ponto analisado correspondentes aos valores de tensões cisalhantes $\tau_{x y}$ e tensões principais maiores $\sigma_{l} \mathrm{e}$ menores $\sigma_{3}$. A partir desses dados é possível determinar o ângulo de atuação da tensão principal maior (ângulo $\beta$ em relação ao plano vertical, considerando sinal negativo no sentido antihorário), as tensões normais atuantes nos planos paralelos $\sigma_{\text {paral. }}$ e perpendiculares $\sigma_{\text {perp. }}$ ao plano da face de montante e tensões normais aos planos verticais $\sigma_{h}$ e horizontais $\sigma_{v}$.

Nas Figuras 21, 22 e 23, estão representadas as trajetórias de tensões para cada ponto analisado durante as condições de carregamento próprio e hidrostático, respectivamente para as linhas $m, n$ e $o$. Essas trajetórias se referem às tensões normais aos planos paralelos e perpendiculares à face. 
Tabela 2. Resultados das tensões cisalhantes, tensões principais maiores e menores, tensões normais aos planos paralelos e perpendiculares a face e tensões verticais e horizontais, em kPa e ângulos de atuação em relação a vertical, em ${ }^{\circ}$, obtidos da simulação numérica para cada ponto analisado.

\begin{tabular}{|c|c|c|c|c|c|c|c|c|c|c|c|c|c|c|c|c|c|c|c|c|c|c|c|c|c|c|c|c|c|c|c|c|}
\hline \multirow{2}{*}{ FASE DE CARREGAMENTO } & \multicolumn{8}{|c|}{ PONTO 1} & \multicolumn{8}{|c|}{ PONTO 2} & \multicolumn{8}{|c|}{ PONTO 3} & \multicolumn{8}{|c|}{ PONTO 4} \\
\hline & $\tau_{\mathrm{xy}}$ & $\sigma_{1}$ & $\sigma_{3}$ & $\beta$ & $\sigma_{\text {paral. }}$. & $\sigma_{\text {perp. }}$ & $\sigma_{\mathrm{v}}$ & $\sigma_{\mathrm{h}}$ & $\tau_{\mathrm{xy}}$ & $\sigma_{1}$ & $\sigma_{3}$ & $\beta$ & $\sigma_{\text {paral. }}$ & $\sigma_{\text {perp. }}$ & $\sigma_{\mathrm{v}}$ & $\sigma_{\mathrm{h}}$ & $\tau_{\mathrm{xy}}$ & $\sigma_{1}$ & $\sigma_{3}$ & $\beta$ & $\sigma_{\text {paral }}$ & $\sigma_{\text {perp. }}$. & $\sigma_{y}$ & $\sigma_{\mathrm{h}}$ & $\tau_{\mathrm{xy}}$ & $\sigma_{1}$ & $\sigma_{3}$ & $\beta$ & $\sigma_{\text {paral. }}$ & $\sigma_{\text {perp. }}$ & $\sigma_{\mathrm{v}}$ & $\sigma_{\mathrm{h}}$ \\
\hline riodo de Construção (20\%) & & & & & & & & & -21 & 209 & 107 & $-12,2$ & 190 & 126 & 204 & 112 & -13 & 509 & 209 & $-2,5$ & 410 & 308 & 508 & 210 & -9 & 768 & 328 & $-1,2$ & 613 & 483 & 768 & 328 \\
\hline Periodo de Construção (40\%) & 30 & 182 & 55 & 14,1 & 104 & 133 & 174 & 63 & 83 & 612 & 170 & 11,0 & 363 & 419 & 596 & 186 & 122 & 1005 & 337 & 10,7 & 633 & 710 & 982 & 360 & 135 & 1773 & 549 & 6,4 & 1183 & 1139 & 1758 & 564 \\
\hline Periodo de Construção (60\%) & 25 & 107 & 229 & 12,1 & 178 & 158 & 112 & 224 & 86 & 613 & 306 & 17,0 & 409 & 510 & 587 & 332 & 158 & 1089 & 431 & 14,4 & 681 & 839 & 1049 & 471 & 224 & 1583 & 601 & 13,6 & 987 & 1197 & 1529 & 655 \\
\hline Periodo de Construção (80\%) & 39 & 82 & 285 & 11,3 & 197 & 170 & 90 & 277 & 123 & 643 & 333 & 26,3 & 393 & 583 & 582 & 394 & 219 & 1151 & 448 & 19,3 & 658 & 941 & 1074 & 524 & 316 & 1701 & 592 & 17,4 & 958 & 1336 & 1602 & 2691 \\
\hline Periodo de & 4 & 76 & 308 & 12,0 & 210 & 4 & 86 & 298 & 39 & 663 & 339 & 29,5 & 388 & 614 & 584 & 418 & 244 & 1179 & 451 & 21,0 & 648 & 982 & 1085 & 545 & 305 & 1748 & 586 & 15,8 & 999 & 1336 & 1662 & 672 \\
\hline & & 80 & 321 & 1,3 & 19 & 188 & 95 & 312 & 34 & 669 & 360 & 30,1 & 405 & 624 & 591 & 438 & 234 & 1179 & 471 & 20,7 & 667 & 983 & 1091 & 559 & 341 & 1746 & 595 & 18,2 & 959 & 1382 & 1634 & 4707 \\
\hline 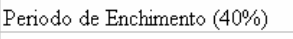 & & 293 & 455 & 12,0 & 323 & 425 & 300 & 448 & 49 & 771 & 542 & 12,7 & 636 & 677 & 760 & 553 & 145 & 1268 & 616 & 13,2 & 876 & 1008 & 1234 & 650 & 253 & 1803 & 696 & 13,6 & 1131 & 1369 & 1742 & 2757 \\
\hline $0 \%)$ & 141 & 782 & 490 & 37,5 & 782 & 490 & 674 & 598 & -70 & 1120 & 672 & $-9,1$ & 1018 & 774 & 1109 & 683 & 17 & 1555 & 774 & 1,2 & 1248 & 1081 & 1555 & 774 & 113 & 2035 & 866 & 5,6 & 1488 & 1413 & 2024 & 4877 \\
\hline $0 \%)$ & -256 & 1191 & 598 & $-29,9$ & 1180 & 609 & 1044 & 745 & -194 & 1532 & 765 & $-15,2$ & 1421 & 877 & 1479 & 818 & -113 & 1933 & 899 & $-6,3$ & 1654 & 1178 & 1921 & 912 & -27 & 2375 & 1024 & $-1,1$ & 1898 & 1501 & 2374 & 41025 \\
\hline$(100 \%)$ & & 1601 & 675 & $-28,5$ & 1578 & 698 & 1391 & 886 & 29 & 1942 & 844 & $-18,4$ & 1823 & 963 & 1833 & 954 & -249 & 2323 & 1004 & $-11,1$ & 2060 & 1267 & 22741 & 1053 & -167 & 2751 & 1160 & $-6,1$ & 2316 & 1596 & 2733 & 1178 \\
\hline \multirow{2}{*}{ FASE DE CARREGAMENTO } & \multicolumn{8}{|c|}{ PONTO 5} & \multicolumn{8}{|c|}{ PONTO 6} & \multicolumn{8}{|c|}{ PONTO 7} & \multicolumn{8}{|c|}{ PONTO 8} \\
\hline & $\tau_{\mathrm{xy}}$ & $\sigma_{1}$ & $\sigma_{3}$ & $\beta$ & $\sigma_{\text {paral. }}$. & $\sigma_{\text {perp. }}$ & $\sigma_{\mathrm{v}}$ & $\sigma_{\mathrm{h}}$ & $\tau_{\mathrm{xy}}$ & $\sigma_{1}$ & $\sigma_{3}$ & $\beta$ & $\sigma_{\text {paral. }}$ & $\sigma_{\text {perp. }}$ & $\sigma_{\mathrm{y}}$ & $\sigma_{\mathrm{h}}$ & $\tau_{\mathrm{xy}}$ & $\sigma_{1}$ & $\sigma_{3}$ & $\beta$ & $\sigma_{\text {paral. }}$. & $\sigma_{\text {perp. }}$ & $\sigma_{\mathrm{r}}$ & $\sigma_{\mathrm{h}}$ & $\tau_{\mathrm{xy}}$ & $\sigma_{1}$ & $\sigma_{3}$ & $\beta$ & $\sigma_{\text {paral. }}$. & $\sigma_{\text {perp. }}$ & $\sigma_{\mathrm{v}}$ & $\sigma_{\mathrm{h}}$ \\
\hline & & & & & & & & & & & & & & & & & 31 & 213 & 84 & 14,4 & 133 & 164 & 205 & 92 & & 749 & 320 & 0,4 & 586 & 483 & 749 & 320 \\
\hline eriodo & & & & & & & & & -15 & 424 & 123 & $-2,9$ & 326 & 221 & 423 & 124 & 93 & 1116 & 409 & 7,6 & 760 & 765 & 1104 & 421 & & 1468 & 629 & 0,5 & 1149 & 948 & 1468 & 3629 \\
\hline & -5 & 87 & 135 & $-6,0$ & 0 & & 88 & 134 & 32 & 1086 & 318 & 2,4 & 769 & 635 & 1085 & 319 & 176 & 1954 & 641 & 8 & 1289 & 1306 & 1930 & 665 & 39 & 2140 & 913 & 8 & 1645 & 1408 & 2139 & 914 \\
\hline & & 183 & 144 & 33,7 & & & 171 & 156 & & 1363 & 431 & & 888 & 906 & 1345 & 449 & 309 & 2466 & 765 & 10,7 & 1519 & 1712 & 2408 & 823 & 128 & 2575 & 1083 & 9 & 1893 & 1765 & 2564 & +1094 \\
\hline eriodo de Construção (100\%) & 32 & 213 & 146 & 36,4 & 151 & 208 & 189 & 170 & 168 & 1462 & 467 & 9,9 & 922 & 1007 & 1433 & 496 & 360 & 2646 & 805 & 11,5 & 1594 & 18572 & 2573 & 878 & 164 & 2728 & 1140 & 6,0 & 1974 & 1894 & 2711 & 11157 \\
\hline erio do de Enchimento (20\%) & 33 & 214 & 144 & 35,3 & 150 & 208 & 191 & 167 & 168 & 1462 & 468 & 9,9 & 922 & 1008 & 1433 & 497 & 359 & 2645 & 807 & 11,5 & 1595 & 18572 & 2572 & 880 & 163 & 2729 & 1140 & 5,9 & 1976 & 1894 & 2712 & 21157 \\
\hline eriodo de Enchimento ( $40 \%)$ & 3 & 222 & 145 & 37,0 & 150 & 217 & 194 & 173 & 167 & 1464 & 503 & 10,2 & 937 & 1030 & 1434 & 533 & 342 & 2636 & 833 & 11,1 & 1617 & 18522 & 2569 & 900 & 146 & 2732 & 1146 & 5,3 & 1997 & 1881 & 2718 & 1159 \\
\hline eriodo de Enchimento (60\%) & -21 & 336 & 287 & $-29,5$ & 335 & 288 & 324 & 299 & 99 & 1535 & 630 & 6,3 & 1100 & 1066 & 1524 & 641 & 270 & 2668 & 924 & 9,0 & 1747 & 18462 & 2625 & 967 & 80 & 2780 & 1183 & 2,9 & 2107 & 1856 & 2776 & 51187 \\
\hline Periodo de Enchimento ( $80 \%)$ & -134 & 748 & 393 & $-24,5$ & 730 & 411 & 687 & 454 & -30 & 1800 & 746 & $-1,6$ & 1437 & 1110 & 1799 & 747 & 150 & 2850 & 1043 & 4,8 & 2029 & 18642 & 28371 & 1055 & -41 & 2942 & 1259 & $-1,4$ & 2355 & 1846 & 2941 & 1260 \\
\hline$(100 \%)$ & & 1187 & 474 & $-22,4$ & 1138 & 523 & 1084 & 577 & 62 & 2193 & 826 & $-6,9$ & 1836 & 1183 & 2174 & 846 & & 3189 & 1159 & 0,7 & 2409 & $1939=$ & 31891 & 1159 & -184 & 3232 & 1358 & $-5,7$ & 2708 & 1883 & 3214 & 41376 \\
\hline \multirow{2}{*}{ FASE DE CARREGAMENTO } & \multicolumn{8}{|c|}{ PONTO 9} & \multicolumn{8}{|c|}{ PONTO 10} & \multicolumn{8}{|c|}{ PONTO 11} & \multicolumn{8}{|c|}{ PONTO 12} \\
\hline & $\tau_{\mathrm{xy}}$ & $\sigma_{1}$ & $\sigma_{3}$ & $\beta$ & $\sigma_{\text {paral. }}$. & $\sigma_{\text {perp. }}$ & $\sigma_{\mathrm{v}}$ & $\sigma_{\mathrm{h}}$ & $\tau_{\mathrm{xy}}$ & $\sigma_{1}$ & $\sigma_{3}$ & $\beta$ & $\sigma_{\text {paral. }}$. & $\sigma_{\text {perp. }}$ & $\sigma_{\mathrm{v}}$ & $\sigma_{\mathrm{h}}$ & $\tau_{\mathrm{xy}}$ & $\sigma_{1}$ & $\sigma_{3}$ & $\beta$ & $\sigma_{\text {paral. }}$. & $\sigma_{\text {perp. }}$. & $\sigma_{\mathrm{r}}$ & $\sigma_{\mathrm{h}}$ & $\tau_{x y}$ & $\sigma_{1}$ & $\sigma_{3}$ & $\beta$ & $\sigma_{\text {paral. }}$. & $\sigma_{\text {perp. }}$ & $\sigma_{\mathrm{r}}$ & $\sigma_{\mathrm{h}}$ \\
\hline & & & & & & & & & & & & & & & & & & & & & & & & & & 762 & 328 & $-0,4$ & 603 & 487 & 762 & 328 \\
\hline$\%)$ & & & & & & & & & & & & & & & & & -39 & 600 & 222 & $-6,0$ & 496 & 326 & 596 & 226 & -1 & 1646 & 705 & $-0,1$ & 1297 & 1055 & 1646 & 505 \\
\hline do $C$ & & & & & & & & & -62 & 489 & 151 & $-10,8$ & 420 & 220 & 477 & 163 & -56 & 1460 & 525 & $-3,4$ & 1165 & 820 & 1457 & 528 & -93 & 2527 & 1065 & $-3,7$ & 207 & 1521 & 2521 & 1071 \\
\hline & 1 & 59 & 140 & 11,6 & 105 & 94 & 62 & 137 & -28 & 1127 & 284 & $-1,9$ & 840 & 571 & 1126 & 285 & $\mid-68$ & 2197 & 620 & $-2,5$ & 1675 & 1142 & 2194 & 623 & -222 & 3154 & 1295 & $-6,9$ & 267 & 178 & 3127 & 1322 \\
\hline & 4 & & 65 & & 111 & & 19 & 78 & 24 & 1368 & 29 & 1 , & 945 & 718 & 1367 & 296 & -75 & 2482 & 634 & $-2,3$ & 1866 & 1251 & 2479 & 637 & -277 & 3396 & 1378 & $-8,0$ & 290 & 187 & 3357 & 1417 \\
\hline & 4 & 07 & 65 & 6 & 1 & & 194 & 78 & 24 & 1368 & 295 & 1 , & 945 & 718 & 1367 & 296 & -76 & 2482 & 634 & $-2,4$ & 1867 & 1250 & 2479 & 637 & -277 & 3396 & 1378 & $-8,0$ & 2903 & 1872 & 3357 & 1417 \\
\hline & 4 & 209 & 62 & ,4 & 110 & 161 & 196 & 75 & 25 & 1368 & 301 & 1,3 & 947 & 723 & 1367 & 302 & -79 & 2480 & 640 & $-2,5$ & 1871 & 1250 & 2477 & 643 & -281 & 3398 & 1377 & $-8,1$ & 2907 & 1868 & 3358 & B 1417 \\
\hline & 47 & 217 & 56 & 17,9 & 108 & 165 & 202 & 71 & 22 & 1371 & 337 & 1,2 & 965 & 743 & 1371 & 337 & -99 & 2483 & 668 & $-3,1$ & 1902 & 1250 & 2478 & 673 & -304 & 3412 & 1375 & $-8,7$ & 2936 & 1852 & 3366 & 51422 \\
\hline & 15 & 272 & 158 & 7,6 & 215 & 215 & 270 & 160 & -37 & 1424 & 426 & $-2,1$ & 1088 & 762 & 1423 & 427 & -164 & 2535 & 727 & $-5,2$ & 2017 & 1246 & 2520 & 742 & -367 & 3477 & 1376 & $-10,2$ & 3033 & 1821 & 3411 & 14442 \\
\hline & -97 & 632 & 88 & 17,2 & 590 & 330 & 602 & 318 & 167 & 643 & 503 & $-8,5$ & 1374 & 773 & 1618 & 528 & -281 & 2716 & 792 & $-8,5$ & 2261 & 12482 & 2674 & 834 & -484 & 3655 & 1393 & -12, & 3253 & 1795 & 3546 & 1502 \\
\hline
\end{tabular}




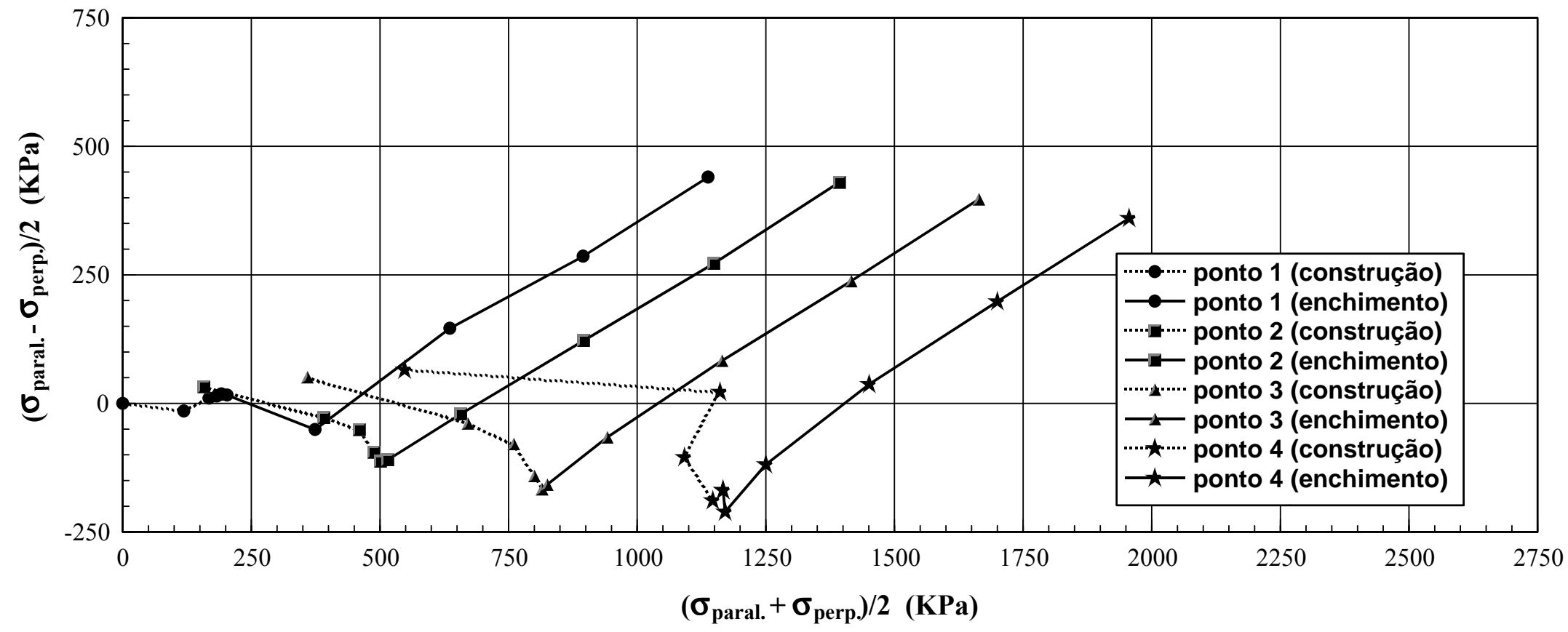

Figura 21. Trajetória de tensões para os pontos da linha “ $m$ ”. 


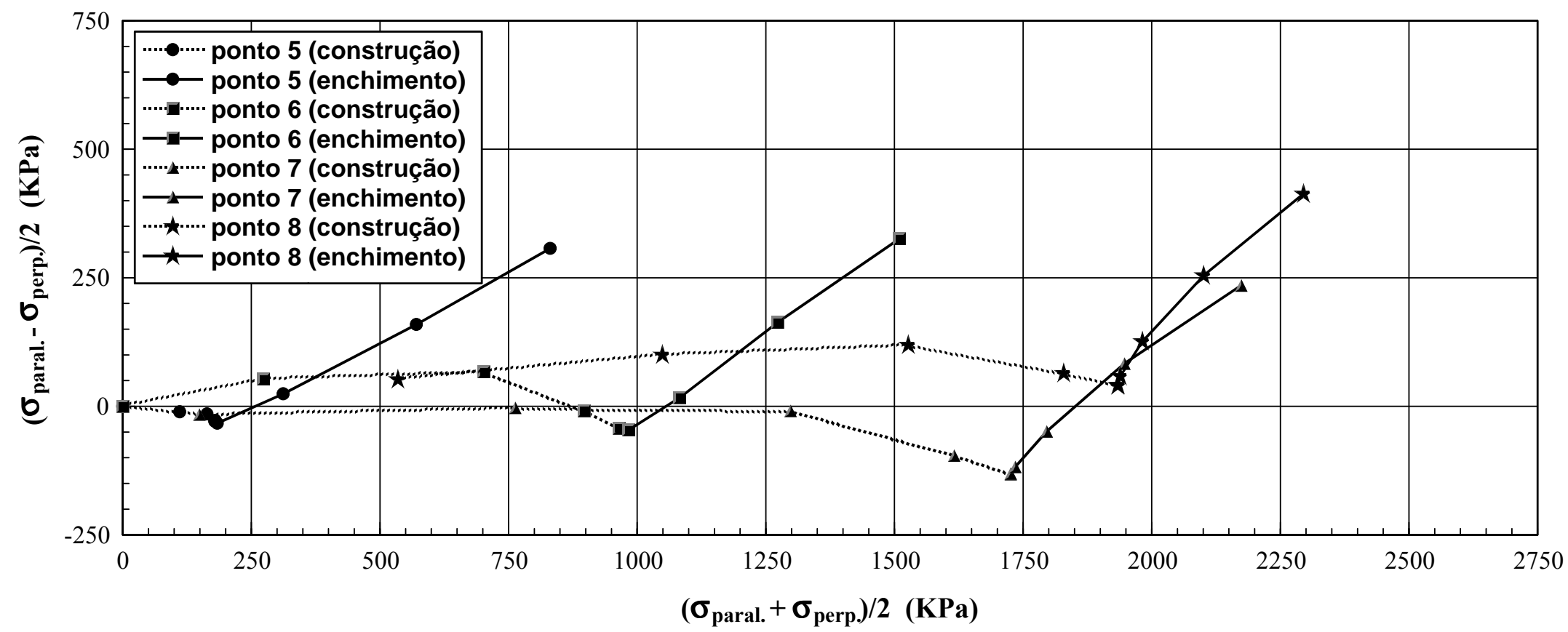

Figura 22. Trajetória de tensões para os pontos da linha " $n$ ". 


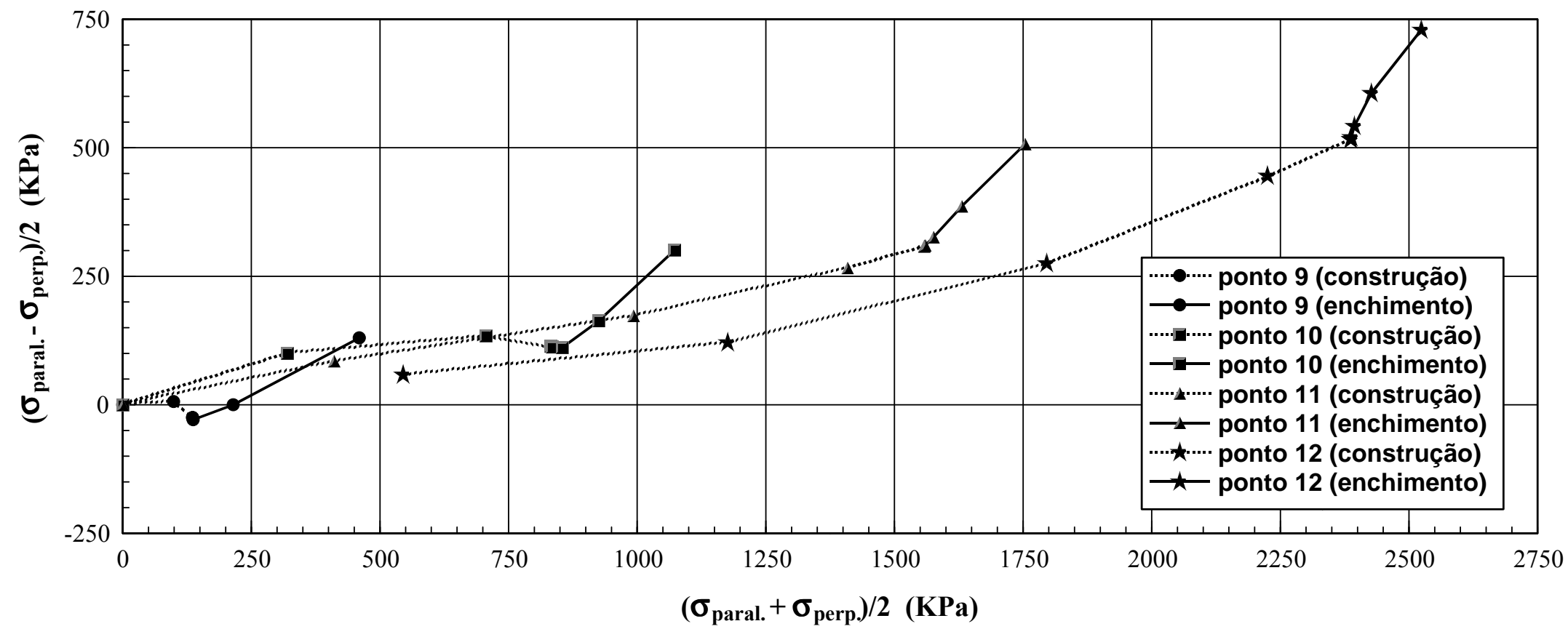

Figura 23. Trajetória de tensões para os pontos da linha " $o$ ". 
Observa-se, através da Figura 20, que há variação de direção da tensão principal maior, acompanhada de um acréscimo de sua magnitude, principalmente, na região inferior de montante, próximo aos espaldares.

A influência do carregamento hidrostático nas tensões geradas no maciço é tanto maior quanto mais próximo da face de montante. As trajetórias de tensões também evidenciam a maior proporcionalidade no desenvolvimento de tensões para os pontos situados próximos a face de montante. Isso se deve ao fato de que as tensões de construção são relativamente baixas na região dos espaldares quando comparadas à região central do maciço.

Ao analisar as tensões paralelas e perpendiculares a face, nota-se que há uma inversão das tensões maiores e menores para alguns pontos do maciço. A tensão normal ao plano perpendicular a face $\sigma_{\text {perp }}$, que é maior na situação de final de construção, passa a ser menor do final do enchimento do reservatório, passando por uma situação onde as duas tensões normais se igualam (tensão desviadora igual a zero). Esse efeito pode ser observado através dos gráficos da Figura 24, tomando como referência a linha de isotropia (inclinação de $45^{\circ}$ ). 

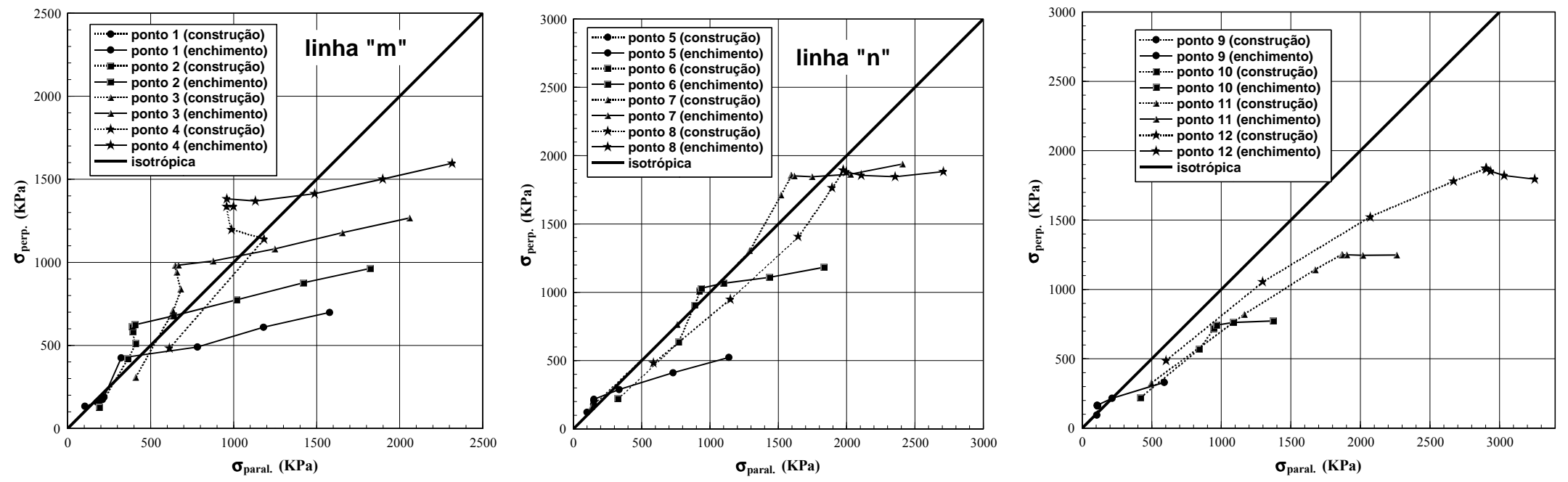

Figura 24. Relação entre as tensões normais aos planos perpendiculares $\sigma_{\text {perp. }}$ e paralelos $\sigma_{\text {paral }}$ a face para os pontos analisados na simulação numérica. 
As trajetórias esboçadas nas Figuras 21, 22 e 23 mostram uma diferença no desenvolvimento das "desviadoras construtivas" para as três linhas $m, n$ e $o$ analisadas. As tensões $\sigma_{\text {perp. }}$ nos pontos da linha $m$ e pontos próximos a face são maiores que as tensões $\sigma_{\text {paral. }}$ no final do período construtivo. Já os pontos analisados em regiões internas ao maciço (região central) apresentam tensões $\sigma_{\text {paral. }}$ sempre maiores que as tensões $\sigma_{\text {perp., }}$ e os carregamentos são próximos aos de compressão confinada.

O fenômeno de inversão das tensões geradas também está relacionado com o desenvolvimento das tensões cisalhantes $\tau_{x y}$. Em geral, para a maioria dos pontos de montante, há um aumento de $\tau_{x y}$ até a situação de $100 \%$ de construção. Ao iniciar o enchimento, observa-se que essas tensões se "aliviam" até se anularem e voltam a se "recarregar" até atingirem a totalidade do carregamento hidrostático. Vale ressaltar que este "alívio" e "recarga" de $\tau_{x y}$ durante o enchimento se processa simultaneamente com o confinamento do maciço. Há situações como, por exemplo, a do ponto 7, em que $\tau_{x y}$ não se anula durante o carregamento hidrostático, somente há um "alívio". Em outros pontos situados em regiões a jusante do eixo (ponto 11 e 12), somente há carregamento de $\tau_{x y}$ durante todo o processo.

As Figuras 21, 22 e 23 mostram que, durante o enchimento do reservatório, as condições de carregamento são similares para os pontos analisados, ou seja, em maior ou menor proporção, as trajetórias formam ângulos de aproximadamente $40^{\circ}$ com a horizontal. A diferença principal consiste no fenômeno de inversões das tensões maiores e menores para a maioria dos pontos da linha $m$ e $n$. Para os pontos em regiões mais confinadas esse fenômeno não ocorre.

Com base na análise feita, nota-se que as condições de variação do estado de tensões são distintas para as diferentes regiões do maciço. No entanto, qualquer simulação em laboratório deve considerar a grandeza das tensões que se desenvolvem no maciço. É claro que o mecanismo de rotação das tensões principais é impossibilitado de ser reproduzido nos ensaios triaxiais. Porém, pode-se tentar avaliar a variação da rigidez de um material granular quando submetido às diferentes condições de carregamento. 


\section{ESTUDO DE LABORATÓRIO}

Este capítulo refere-se a um estudo experimental realizado em laboratório, com material de enrocamento em escala reduzida, visando determinar parâmetros de deformabilidade e resistência. Os resultados serão posteriormente discutidos e analisados de forma que sejam úteis para posteriores análises de desempenho em estruturas de enrocamento.

\subsection{Metodologia e programação de ensaio}

A investigação de laboratório é importante para o estudo em questão e foi desenvolvida no Centro Tecnológico de Engenharia Civil (Laboratório de Mecânica das Rochas) de Furnas Centrais Elétricas S. A., na cidade de Aparecida de Goiânia-GO. Dessa forma, a programação dos ensaios foi realizada obedecendo à disponibilidade dos materiais, equipamentos e metodologia do laboratório.

Com base nos níveis e nas trajetórias de tensões simuladas no capítulo anterior, pretendeu-se realizar ensaios de cisalhamento direto e tri-triaxiais com diferentes condições de confinamento. Antes da realização destes, foi necessário caracterizar o material escolhido (propriedades da rocha de origem) e definir uma granulometria e densidade relativa para o material.

\subsubsection{Cisalhamento direto}

É importante, no estudo em questão, que se investigue as propriedades de resistência do material, pois alguns modelos constitutivos para análise de deformabilidade também necessitam de parâmetros de resistência. Dessa forma, optou-se em realizar ensaios de cisalhamento direto, já que o laboratório em questão dispunha de equipamento e metodologia para esse fim.

Os ensaios de cisalhamento direto foram realizados objetivando uma envoltória de resistência para analisar a variação do ângulo de atrito interno com o nível de confinamento. As tensões 
normais aplicadas foram de 100,250,500, 750 e $900 \mathrm{kPa}$, obedecendo à limitação de carga da prensa. Assim, foi possível avaliar a variação da resistência ao corte na ruptura com o nível de confinamento.

O equipamento para realização do ensaio de cisalhamento é uma prensa do tipo SBEL, onde a amostra a ser ensaiada tem formato cilíndrico com diâmetro máximo de $43 \mathrm{~cm}$ e altura de $32 \mathrm{~cm}$ (Figura 25). Para a modelagem de uma amostra, a quantidade pré-estabelecida de material foi dividida em 3 partes iguais para a compactação da amostra em camadas, até obter-se a densidade desejada. O sistema de obtenção dos dados é informatizado, sendo que os gráficos e demais resultados são fornecidos automaticamente.

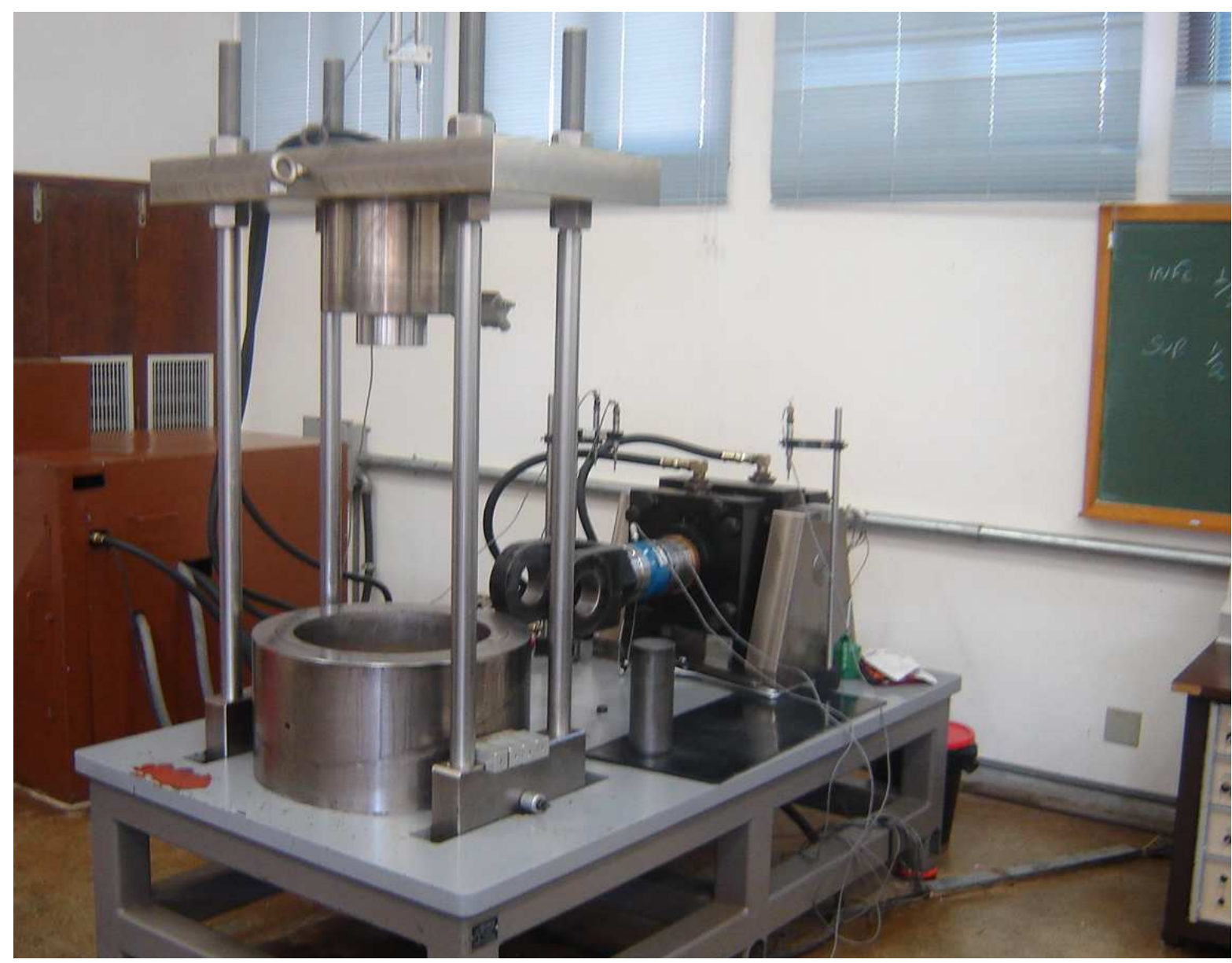

Figura 25. Equipamento de cisalhamento direto (prensa SBEL), Furnas Centrais Elétricas S.A. 


\subsubsection{Triaxial}

O estudo tensão-deformação do material granular foi o enfoque principal da pesquisa de laboratório. O objetivo principal foi avaliar a rigidez do material com relação à variação do nível de confinamento. Além disso, tornou-se interessante investigar o comportamento de deformação quando a amostra foi submetida a diferentes condições de carregamento. Vale lembrar que os ensaios triaxiais executados não são padronizados e não possuem normas e metodologia de procedimento.

O equipamento para o ensaio triaxial foi desenvolvido no próprio laboratório de Furnas. Nada mais é, do que uma caixa cúbica, composta por chapas de aço nas suas faces. A dimensão das placas é de $50 \times 50 \mathrm{~cm}$, sendo que uma folga de aproximadamente $15 \mathrm{~mm}$ é deixada nas arestas para que as deformações sejam processadas. As faces, em cada direção, são tencionadas através de macacos hidráulicos e as respectivas forças são medidas através de células de cargas. Para medir as deformações em cada direção, são utilizados medidores do tipo LVDTs (Figura 26). Os dados de tensão-deformação nas 3 direções são captados por um sistema de aquisição de dados informatizado que processa as informações a cada segundo. 


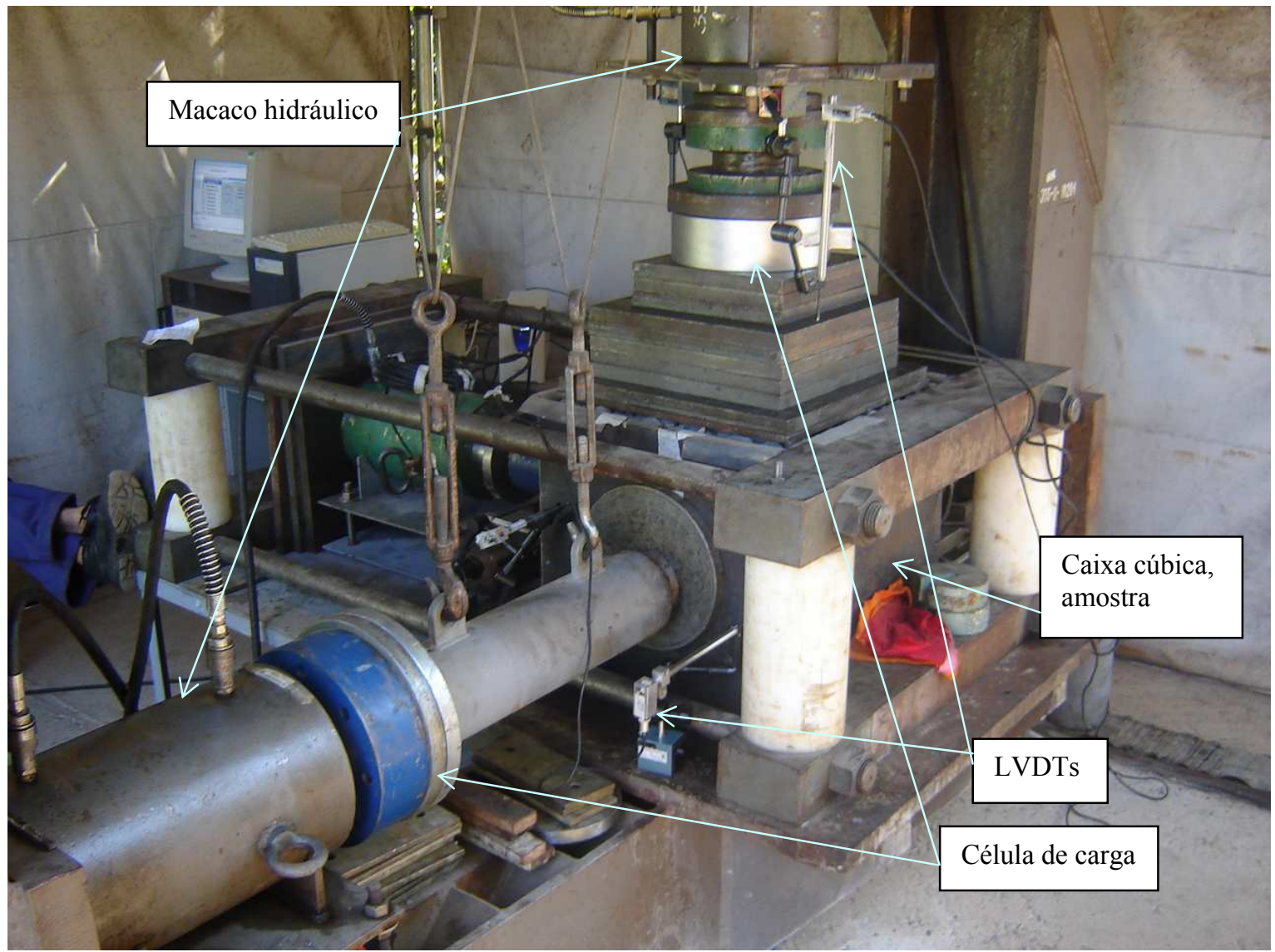

Figura 26. Equipamento tri-triaxial, Furnas Centrais Elétricas S.A.

Devido à robustez do equipamento e as improvisações na metodologia de ensaio, várias condicionantes devem ser levadas em consideração nos ensaios triaxiais, dentre elas:

- Imprecisão de leitura dos instrumentos de medição;

- Imprecisão na gabaritagem das chapas de aço que envolve o material;

- Interferência dos grãos nos cantos da caixa e arestas entre chapas;

- Nenhuma consideração dos tempos de carregamento.

Considerando isso e alguns outros fatores que possam interferir nos resultados, a metodologia de ensaio se procedeu da seguinte forma:

- Primeiramente, a caixa cúbica, composta de chapas de aço, é montada com o auxílio de cantoneiras parafusadas que fixam as placas de aço no gabarito desejado. Posteriormente, essa caixa é posicionada conforme os eixos de aplicação das cargas nas 3 direções. Em 
seguida, a caixa é revestida internamente com plásticos nas arestas para que o material não escape pelos cantos. A seqüência é lançar o material no interior da caixa;

- A quantidade de material de enrocamento é pré-determinada em uma quantidade de 267,5 $\mathrm{kg}$ distribuídos na granulometria desejada, de forma que se atinja uma densidade relativa de $80 \%\left(\gamma_{80 \%}=19,027 \mathrm{kN} / \mathrm{m}^{3}\right)$ na amostra cúbica de $52 \mathrm{~cm}$ de aresta. A densidade é atingida através da compactação controlada em 3 camadas iguais;

- Com o material já compactado na densidade desejada, o próximo procedimento é posicionar as chapas superiores e aplicar uma pequena carga nas faces para que seja possível desparafusar as cantoneiras sem que haja desmonte da amostra.

- Dessa maneira, é possível ajustar e zerar os instrumentos de medida para iniciar o processo de carregamento dos ensaios.

Como o equipamento permite controlar as tensões nas três direções principais, esse ensaio é chamado de tri-triaxial ou triaxial verdadeiro. Por motivos de praticidade na execução e interpretação dos resultados, optou-se por considerar valores iguais para as tensões de confinamento, ou seja, $\sigma_{2}$ igual a $\sigma_{3}$.

O plano de ensaio para a realização dos ensaios triaxiais foi elaborado de forma a contemplar uma quantidade de ensaios dentro de um prazo limitado de tempo.

A idéia inicial era realizar alguns ensaios tri-triaxiais com carregamentos convencionais, capazes de fornecerem parâmetros de deformabilidade que pudessem alimentar modelos mais complexos que os elástico-lineares, e que considerassem a variabilidade dos parâmetros para situações de variação do nível de confinamento.

Para isso, pré determinou-se que seriam realizados 3 ensaios de carregamento axial com tensões confinantes distintas, 2 ensaios de carregamento com ciclos de descarga-recarga também com diferentes tensões confinantes e 1 ensaio de carregamento isotrópico.

Alguns outros ensaios foram programados visando a interpretação do comportamento tensãodeformação do material, quando este é submetido a trajetórias de tensões próximas às que podem 
ocorrer no interior do maciço de uma BEFC. O fenômeno de inversão das tensões maiores e menores, observado nas simulações do capítulo 5, serviu de base para programar o restante dos ensaios.

Uma situação de carregamento diferencial em planos ortogonais similares aos que ocorrem em planos paralelos e perpendiculares a face de montante em BEFC pode ser reproduzida em ensaios tri-triaxiais, considerando todas as restrições que envolvem a representatividade das simulações numéricas e laboratoriais, em relação ao que realmente ocorre no campo.

Com isso, programou-se 3 ensaios chamados de ensaios de carregamento "transversal" com diferentes níveis de confinamento, objetivando avaliar o fenômeno de inversão das tensões maiores e menores.

A Tabela 3, resumidamente, apresenta os valores das cargas programadas para todos os ensaios pretendidos, levando em consideração a grandeza das tensões simuladas no capítulo 5. Em seguida, são esboçadas, através da Figura 27, as trajetórias de tensões que se pretende aplicar nos ensaios denominados "transversais". 
Tabela 3. Programação de cargas para os ensaios tri-triaxiais.

\begin{tabular}{|c|c|c|c|c|c|}
\hline Tipo de Ensaio & \begin{tabular}{c|} 
Tensão \\
Inicial \\
Confinante \\
\end{tabular} & $\begin{array}{r}\text { Tensão } \\
\text { Inicial } \\
\text { Axial } \\
\end{array}$ & $\begin{array}{c}\text { Tensão } \\
\text { Final } \\
\text { Confinante } \\
\end{array}$ & $\begin{array}{l}\text { Tensão } \\
\text { Final } \\
\text { Axial } \\
\end{array}$ & Observação \\
\hline $\begin{array}{l}\text { Carregamento } \\
\text { Convencional } 1\end{array}$ & 100 & 100 & 100 & Ruptura* & $\begin{array}{l}\text { Acréscimo de tensão axial até o limite } \\
\text { de carga do equipamento }\end{array}$ \\
\hline $\begin{array}{l}\text { Carregamento } \\
\text { Convencional } 2\end{array}$ & 500 & 500 & 500 & Ruptura* & $\begin{array}{l}\text { Acréscimo de tensão axial até o limite } \\
\text { de carga do equipamento }\end{array}$ \\
\hline $\begin{array}{l}\text { Carregamento } \\
\text { Convencional } 3\end{array}$ & 1000 & 1000 & 1000 & Ruptura* & $\begin{array}{l}\text { Acréscimo de tensão axial até o limite } \\
\text { de carga do equipamento }\end{array}$ \\
\hline $\begin{array}{l}\text { Carregamento com } \\
\text { Descarregamento e } \\
\text { Recarregamento } 1\end{array}$ & 200 & 200 & 200 & Ruptura* & $\begin{array}{c}\text { Acréscimo de tensão axial até o limite } \\
\text { de carga do equipamento, com ciclos } \\
\text { de descargas e recargas realizados } \\
\text { para relação de tensão } \\
\text { axial/confinante de } 2 \text { e } 3,5\end{array}$ \\
\hline $\begin{array}{l}\text { Carregamento com } \\
\text { Descarregamento e } \\
\text { Recarregamento } 2\end{array}$ & 700 & 700 & 700 & Ruptura* & $\begin{array}{c}\text { Acréscimo de tensão axial até o limite } \\
\text { de carga do equipamento, com ciclos } \\
\text { de descargas e recargas realizados } \\
\text { para relação de tensão } \\
\text { axial/confinante de } 2 \text { e } 3,5\end{array}$ \\
\hline $\begin{array}{l}\text { Carregamento } \\
\text { Isotrópico }\end{array}$ & 0 & 0 & - & - & $\begin{array}{l}\text { O ensaio se procede até o limite de } \\
\text { carga do equipamento }\end{array}$ \\
\hline $\begin{array}{l}\text { Carregamento } \\
\text { Transversal } 1\end{array}$ & 200 & 80 & - & - & $\begin{array}{l}\text { O ensaio se procede até o limite de } \\
\text { carga do equipamento, sendo o } \\
\text { acréscimo de tensão confinante igual a } \\
\text { aproximadamente } 15 \% \text { do acréscimo } \\
\text { de tensão axial }\end{array}$ \\
\hline $\begin{array}{l}\text { Carregamento } \\
\text { Transversal } 2\end{array}$ & 500 & 200 & - & - & $\begin{array}{l}\text { O ensaio se procede até o limite de } \\
\text { carga do equipamento, sendo o } \\
\text { acréscimo de tensão confinante igual a } \\
\text { aproximadamente } 15 \% \text { do acréscimo } \\
\text { de tensão axial }\end{array}$ \\
\hline $\begin{array}{l}\text { Carregamento } \\
\text { Transversal } 3\end{array}$ & 1000 & 400 & - & - & $\begin{array}{l}\text { O ensaio se procede até o limite de } \\
\text { carga do equipamento, sendo o } \\
\text { acréscimo de tensão confinante igual a } \\
\text { aproximadamente } 15 \% \text { do acréscimo } \\
\text { de tensão axial }\end{array}$ \\
\hline
\end{tabular}

* Ruptura condicionada ao limite de carga do equipamento 


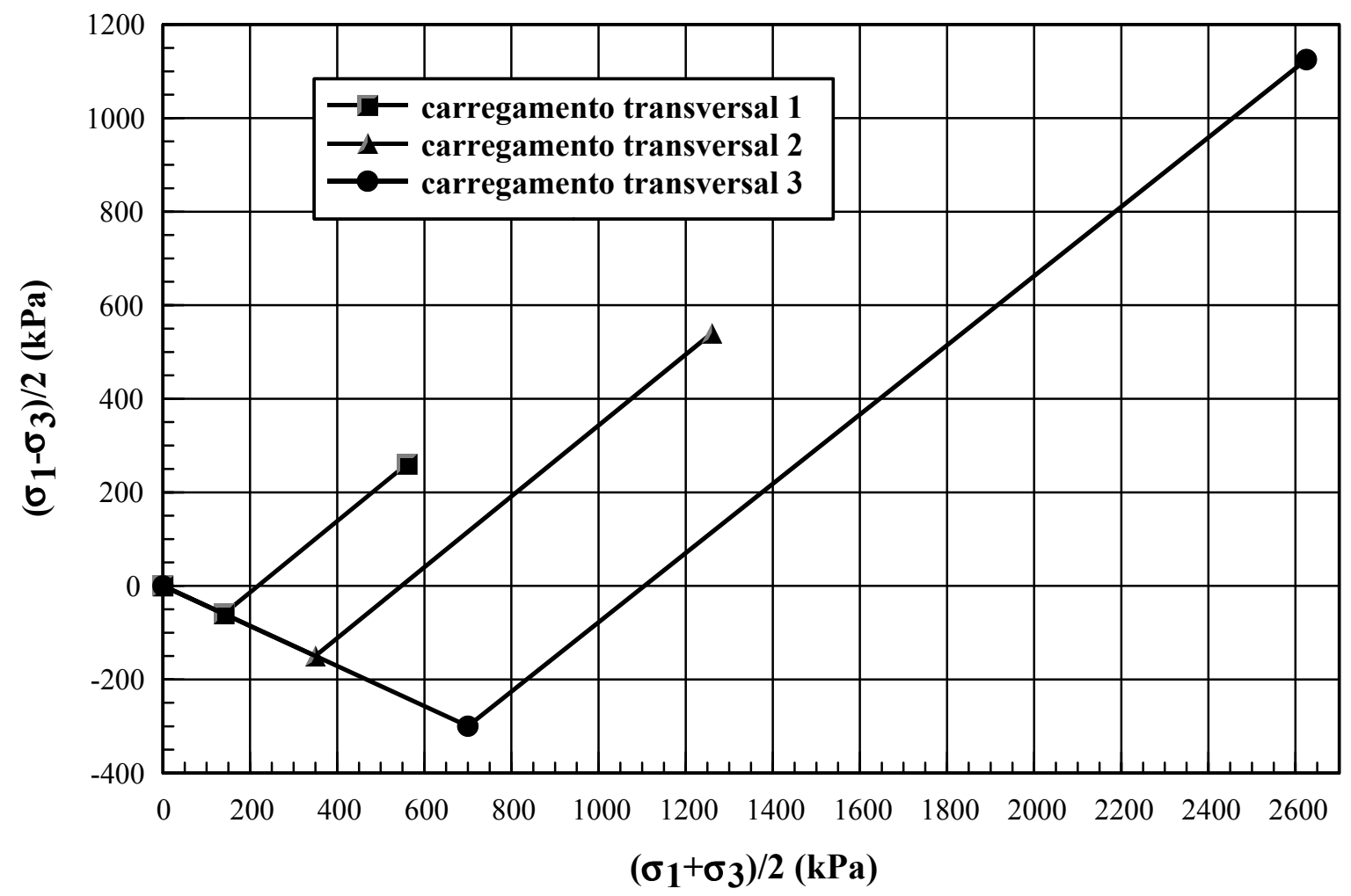

Figura 27. Trajetória de tensões para ensaios de carregamento transversal.

Os 6 primeiros ensaios da Tabela 3 podem fornecer parâmetros suficientes para análises de deformação através de modelos mais complexos, como por exemplo, o modelo hiperbólico. Caso as curvas de tensão-deformação não se aproximem de hipérboles, ignoram-se as metodologias de busca de parâmetros através deste modelo e adota-se uma metodologia mais simplificada de apresentação dos módulos de rigidez extraídos das curvas tensão-deformação para cada tipo de ensaio, levando em consideração as diferentes condições iniciais de confinamento.

Já os ensaios transversais, são tentativas de simulação das condições de carregamento, especificamente para maciços de BEFC quando submetida a carregamento próprio e hidrostático. A intenção principal é fornecer diretrizes para análises e interpretações de deflexões que ocorrem na face de montante de BEFC. 


\subsection{Resultados obtidos}

\subsubsection{Ensaios Iniciais}

\subsubsection{Caracterização da rocha de origem}

O material de enrocamento a ser caracterizado é proveniente das escavações obrigatórias de rocha da obra da barragem de Campos Novos - SC. Constitui-se originalmente de uma litologia de basalto são, de cor cinza escuro, muito consistente e maciço, com excelentes propriedades geomecânicas.

O material disponível se encontra em forma de matacões, que deram origem aos fragmentos na granulometria desejada e aos testemunhos que foram extraídos para a realização dos ensaios de caracterização.

A caracterização do material resume-se em:

- Peso específico aparente seco $\left(\mathrm{kN} / \mathrm{m}^{3}\right)$;

- Absorção (\%);

- Porosidade $(\%)$

- Resistência à compressão simples (MPa);

- Módulo de Young (GPa);

- Coeficiente de Poisson;

- Resistência à tração em compressão diametral (Mpa).

Para a determinação das 3 primeiras grandezas citadas acima, é necessário a seleção de uma amostra representativa constituída por no mínimo 10 fragmentos de rocha, contendo cada um a massa de aproximadamente $250 \mathrm{~g}$.

Os ensaios para a determinação de resistência a compressão simples, módulo de Young e coeficiente de Poisson são os mesmos e requerem a extração e moldagem dos corpos de prova. 
Recomenda-se que o número mínimo de corpos de prova a serem ensaiados seja 5 e que estes sejam em formato cilíndrico, com relação altura/diâmetro variando entre 2,5 a 3,0 e com diâmetro mínimo de $54 \mathrm{~mm}$.

Já a resistência à tração foi realizada através do método indireto, ou seja, compressão diametral que também é conhecido como Ensaio Brasileiro. Os corpos de prova deveriam ter forma cilíndrica, com diâmetro não inferior a $54 \mathrm{~mm}$ e espessura aproximadamente igual à metade do diâmetro. O número mínimo de corpos de prova também deveria ser de 5.

As propriedades mecânicas da rocha e as características físicas e geométricas dos fragmentos estão representados na Tabela 4.

Tabela 4. Propriedades mecânicas da rocha e as características físicas e geométricas dos fragmentos.

\begin{tabular}{|c|c|}
\hline Resistência à compressão simples (MPa) & 292,4 \\
\hline Módulo de Young (GPa) & 73,2 \\
\hline Coeficiente de Poisson & 0,24 \\
\hline Resistência à tração por compressão diametral (MPa) & 19,1 \\
\hline Peso específico seco $\left(\mathrm{kN} / \mathrm{m}^{3}\right)$ & 28,70 \\
\hline Peso específico saturado $\left(\mathrm{kN} / \mathrm{m}^{3}\right)$ & 28,87 \\
\hline Absorção (\%) & 0,57 \\
\hline Porosidade aparente (\%) & 1,63 \\
\hline Coeficiente de forma dos grãos (Fumagalli 1969) $\left(\mathrm{n}^{\circ}\right.$ de amostras $\left.=70\right)$ & 0,16 \\
\hline Coeficiente de forma dos grãos (Marsal 1973) $\left(\mathrm{n}^{\circ}\right.$ de amostras $\left.=70\right)$ & 0,58 \\
\hline
\end{tabular}

Nota-se, através do coeficiente de forma dos grãos, que o material após ser britado apresentou-se bastante lamelar. Isso pode estar relacionado à consistência da rocha e ao processo de britagem.

O valor da resistência à tração, obtido através do ensaio de compressão diametral é menor que $10 \%$ da sua resistência à compressão simples. 


\subsubsection{Granulometria}

A curva granulométrica foi determinada hipoteticamente, de forma que o material granular apresenta-se não muito uniforme, nem com muitos finos. A consideração principal é com relação aos critérios de efeito de escala, ou seja, limitar o diâmetro máximo dos grãos em 1/5 do diâmetro da menor amostra para que não haja influência dos maiores grãos na amostra, Veiga Pinto (1983). Dessa forma, estabeleceu-se um diâmetro máximo passante na peneira de 3" ( 7,6cm) e retido na peneira $2 "(\sim 5.1 \mathrm{~cm})$, pois a menor amostra é referente aos ensaios de cisalhamento direto (prensa SBEL- $\varnothing=43 \mathrm{~cm}$ ).

Holltz e Gibbs (1956) recomendam também que o número de partículas com diâmetro máximo não ultrapasse $30 \%$. Assim, a granulometria foi definida através da curva da Figura 28.

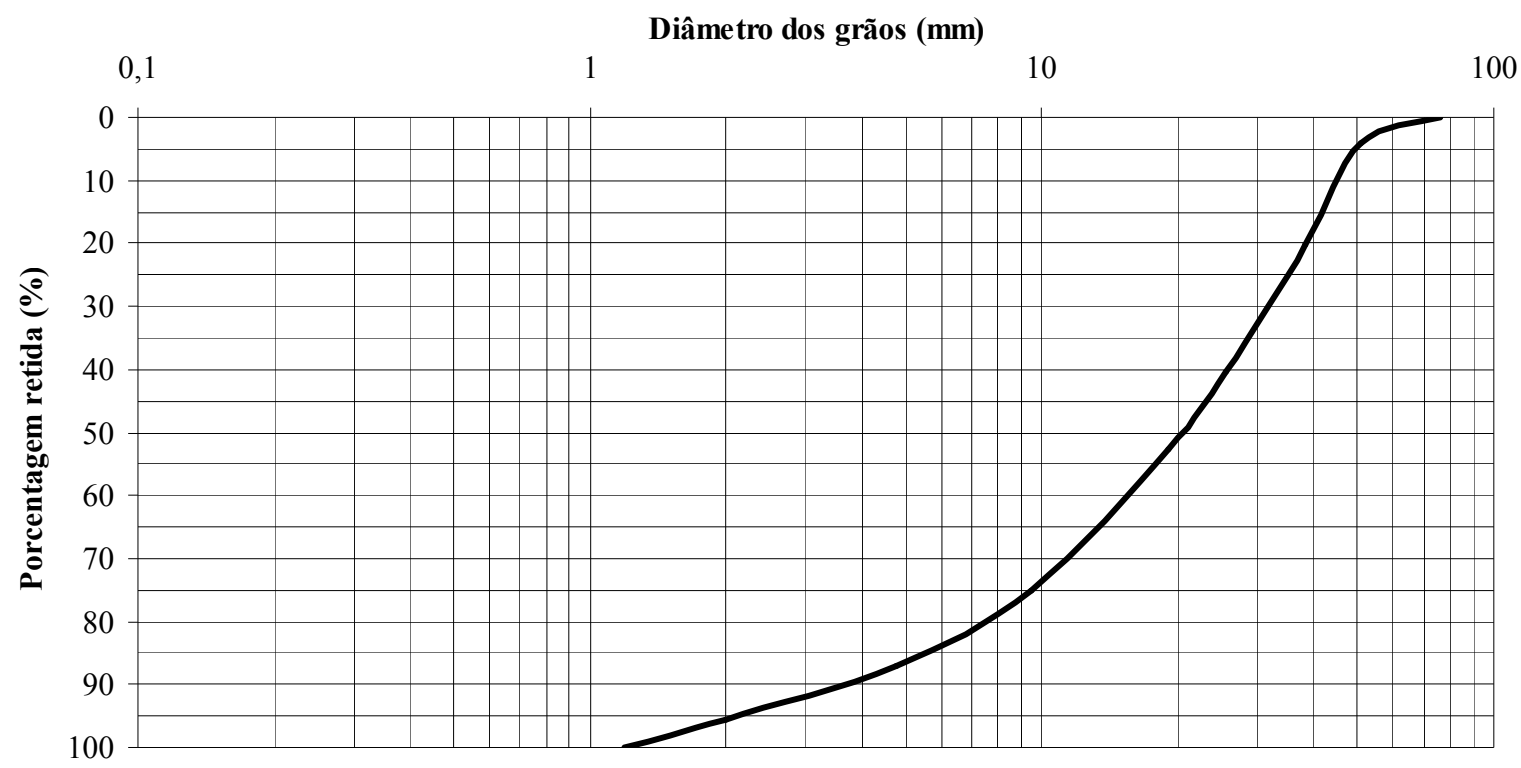

Figura 28. Curva granulométrica obtida para o material de ensaio.

Dessa forma, obteve-se um material não muito uniforme cujo coeficiente de uniformidade $C_{u}$ é aproximadamente igual a 6,66. 


\subsubsection{Densidade Relativa}

Para se obter um valor de massa específica referente a uma densidade relativa é necessário conhecer a massa específica máxima e mínima do material na granulometria desejada. Sendo assim, a densidade relativa de uma determinada massa específica natural desejada é obtida pela Equação 20:

$$
D_{r}(\%)=\frac{\gamma_{\max }}{\gamma_{\text {nat }}} \cdot \frac{\left(\gamma_{\text {nat }}-\gamma_{\min }\right)}{\left(\gamma_{\max }-\gamma_{\text {min }}\right)} \cdot 100
$$

onde:

$\gamma_{\text {nat }}=$ massa específica natural desejada $\left(\mathrm{kN} / \mathrm{m}^{3}\right)$

$\gamma_{\max }=$ massa específica máxima do enrocamento $\left(\mathrm{kN} / \mathrm{m}^{3}\right)$

$\gamma_{\min }=$ massa específica mínima do enrocamento $\left(\mathrm{kN} / \mathrm{m}^{3}\right)$

Para a determinação experimental da massa específica máxima e mínima, utilizou-se uma câmara de compactação de aço, com formato cilíndrico com 1 metro de diâmetro interno e uma quantidade de material de $650 \mathrm{~kg}$ que foram divididos em duas camadas. As densidades máximas e mínimas foram obtidas através da média de um total de 3 ensaios. $\mathrm{O}$ estado fofo consiste no lançamento do material previamente misturado, praticamente sem altura de queda, dentro da câmara cilíndrica. $\mathrm{O}$ estado denso é obtido através da compactação, de cada camada, com uma placa vibratória por um período máximo de 25 minutos, tempo a partir do qual houve constância nas leituras.

Os resultados dos ensaios de determinação das densidades máximas e mínimas estão apresentados na Tabela 5, juntamente com o índice de quebra $B_{\mathrm{g}}$, Marsal (1973). 
Tabela 5. Resultados do ensaio de compactação (densidade relativa).

\begin{tabular}{|l|c|c|c|}
\cline { 2 - 3 } \multicolumn{1}{c|}{} & \multicolumn{2}{c|}{ Densidade $\left(\mathrm{kN} / \mathrm{m}^{3}\right)$} & \multirow{2}{*}{ Bg (\%) } \\
\cline { 2 - 3 } \multicolumn{1}{c|}{} & Máxima & Mínima & \\
\hline Ensaio 1 & 20,26 & 16,60 & 0,95 \\
\hline Ensaio 2 & 19,66 & 16,06 & - \\
\hline Ensaio 3 & 19,60 & 16,38 & 0,17 \\
\hline Média & 19,84 & 16,35 & 0,56 \\
\hline
\end{tabular}

Dessa forma, admitiu-se que os ensaios de cisalhamento e triaxiais serão realizados com uma densidade relativa de $80 \%$, pois se estima que o enrocamento do maciço de BEFC na região de montante possui uma densidade relativa em torno desse valor. Com isso, tem-se que a densidade natural para os ensaios pretendidos seja de aproximadamente $19,0 \mathrm{kN} / \mathrm{m}^{3}$.

\subsubsection{Ensaio de Cisalhamento Direto}

Através do ensaio de cisalhamento direto é possível obter, além da envoltória de resistência, as curvas de deformação horizontal e vertical quando da aplicação da tensão cisalhante. Os gráficos esboçados na Figura 29 mostram respectivamente os deslocamentos horizontais e verticais que ocorrem no processo de cisalhamento para as diferentes tensões normais aplicadas $(100,250$, $500,750$ e $900 \mathrm{kPa})$. 

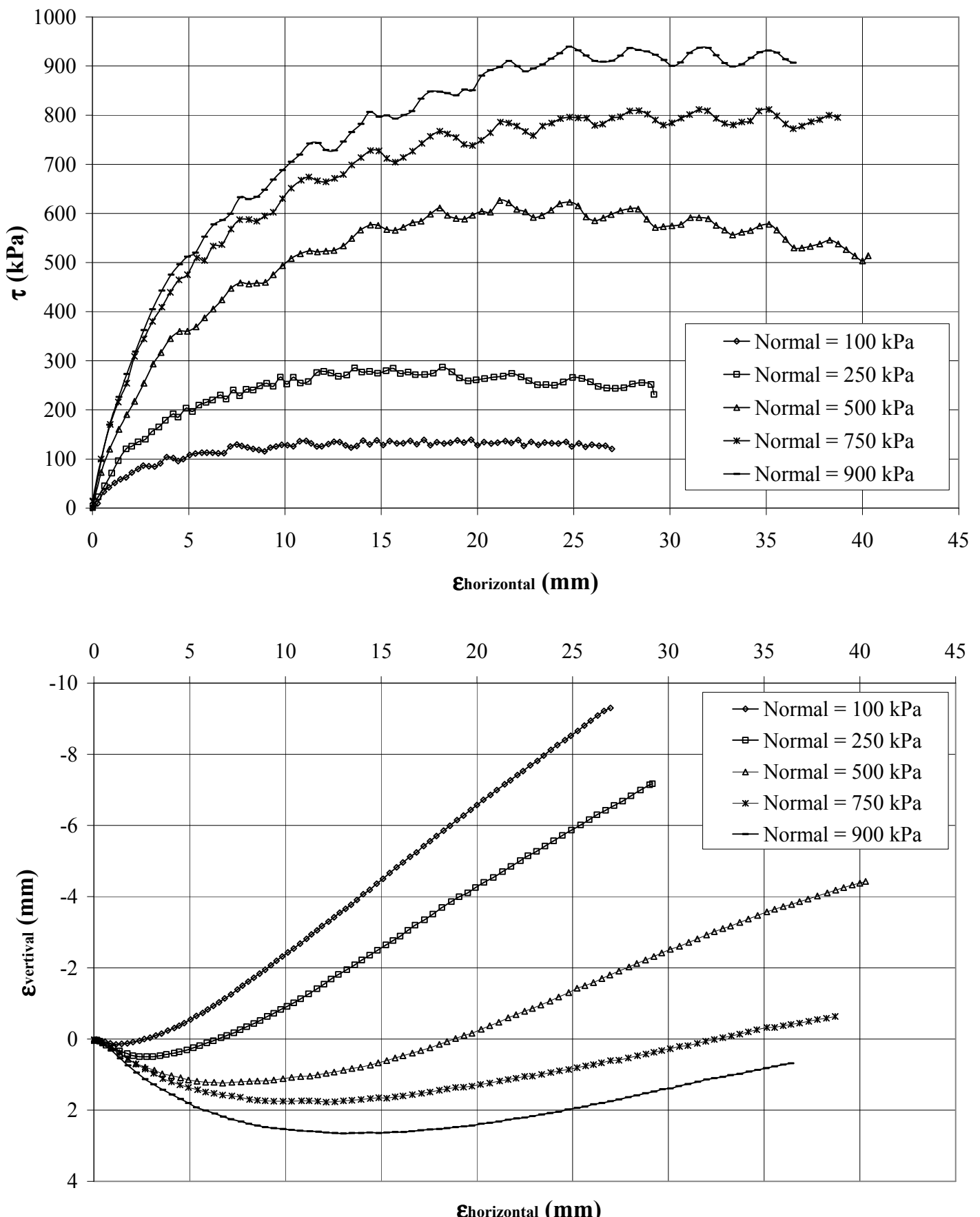

Figura 29. Curvas de tensão-deformação para ensaios de cisalhamento direto com diferentes tensões normais. 
Os resultados de cisalhamento obtidos mostram que o comportamento de deformação é típico de materiais granulares compactos. Primeiramente, observa-se que a tensão cisalhante cresce mais rapidamente com as deformações para maiores tensões normais aplicadas, até atingir o pico. No entanto, a tensão cisalhante não apresenta decréscimo acentuado após atingir ruptura, como geralmente ocorre em materiais compactos.

Com relação à variação de volume, observa-se que os corpos de prova apresentam uma redução de volume no início do carregamento cisalhante. Para as amostras ensaiadas sob baixas tensões normais, a redução de volume é pequena, acompanhado de uma dilatância durante a ruptura. Para as amostras ensaiadas sob altas tensões normais, observa-se uma maior redução de volume durante a realização dos ensaios. Esse comportamento está diretamente relacionado ao entrosamento entre as partículas no processo de carregamento para as diferentes tensões normais aplicadas.

A Figura 30 apresenta as envoltórias de resistência de ruptura e residual, obtidas através do ensaio de cisalhamento direto, seguido da variação do ângulo de atrito com a tensão normal aplicada (Figura 31). Vale considerar que, para material granular, a envoltória é aproximadamente uma hipérbole e segue uma equação do tipo (De Mello 1977):

$$
\tau=\mathrm{A} \cdot \sigma^{b}
$$

Onde A é dimensional e $\mathrm{b}$ adimensional. 


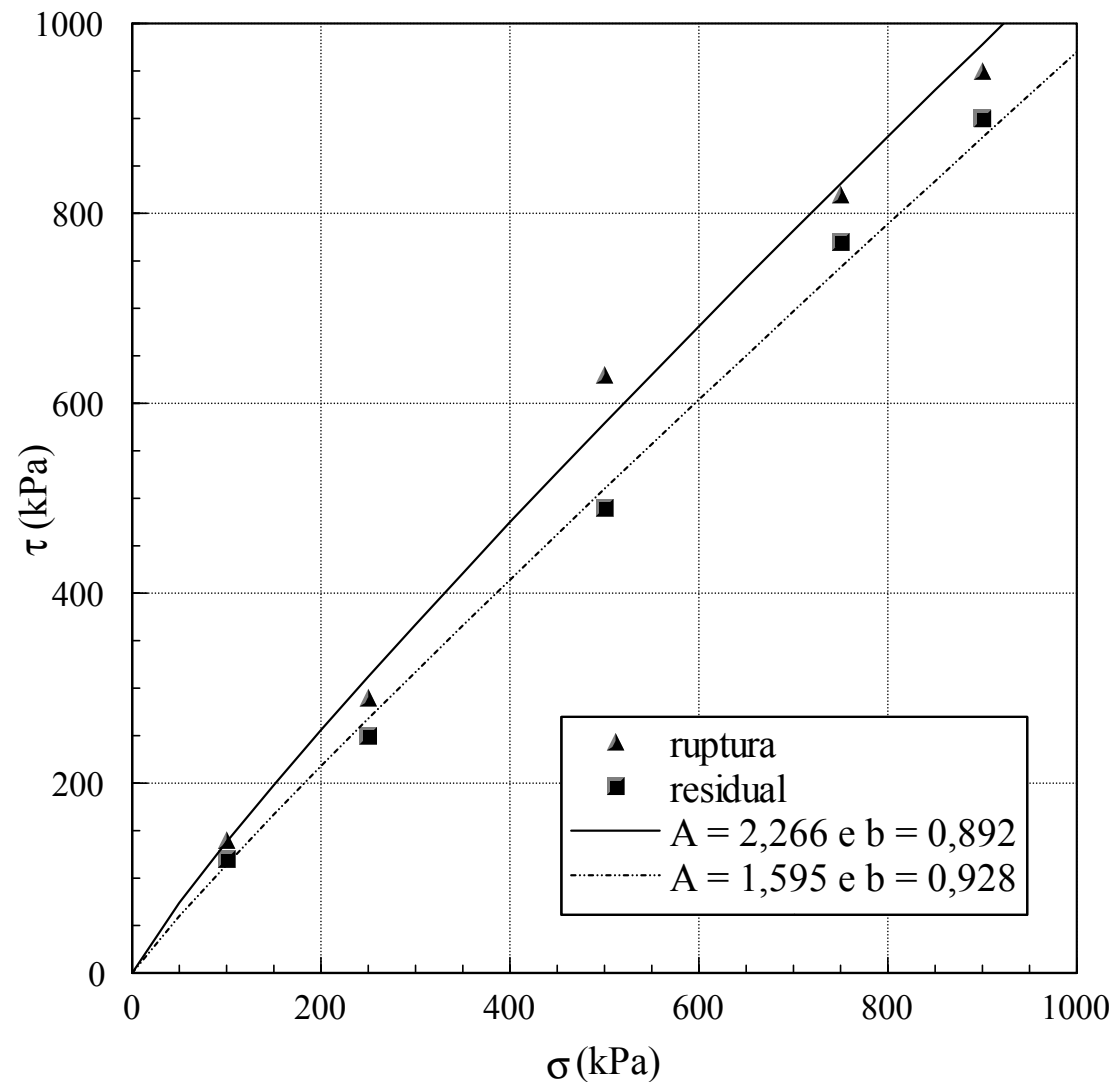

Figura 30. Envoltória de resistência do material ensaiado.

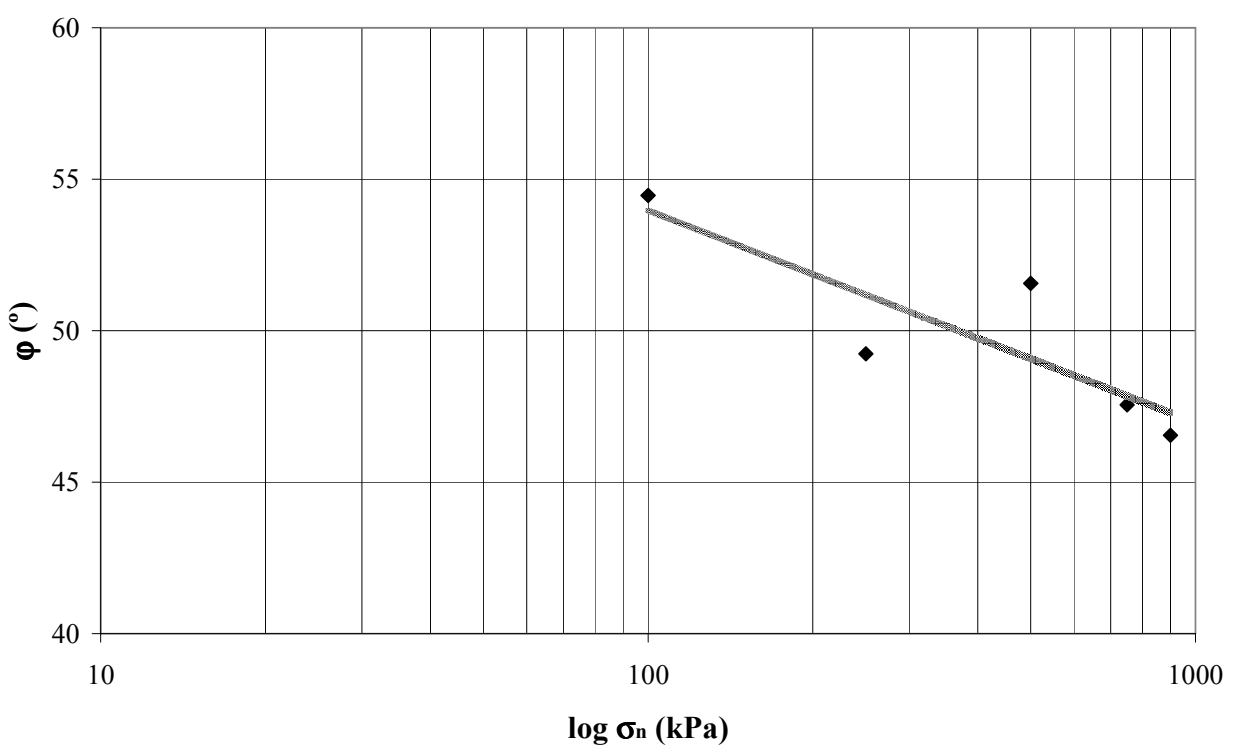

Figura 31. Variação do ângulo de atrito com a tensão normal para o material ensaiado. 
Nota-se que a envoltória de resistência realmente se aproxima de uma curva hipérbole, como é esperado em materiais granulares compactos. Observa-se claramente que o ângulo de atrito decresce com o confinamento. Esse fenômeno é diretamente relacionado com o imbricamento e o fator de quebra entre os grãos quando das solicitações de cisalhantes. O maior confinamento proporciona maiores tensões de imbricamento entre grãos, aumentando assim a suscetibilidade à quebra dos cantos, proporcionando menores valores de ângulo de atrito de ruptura.

\subsubsection{Ensaio Triaxial}

Conforme apresentado na programação de ensaios, o plano de carga inicialmente apresenta ensaios de carregamento convencional, ou seja, carregamento axial até a ruptura para tensões de confinamento de 100, 500 e $1000 \mathrm{kPa}$. Os resultados de deformação axial e volumétrica estão respectivamente apresentados na Figura 32, 33 e 34 para as fases iniciais de confinamento, de carregamento da tensão desviadora e descarregamento do ensaio após a ruptura. 

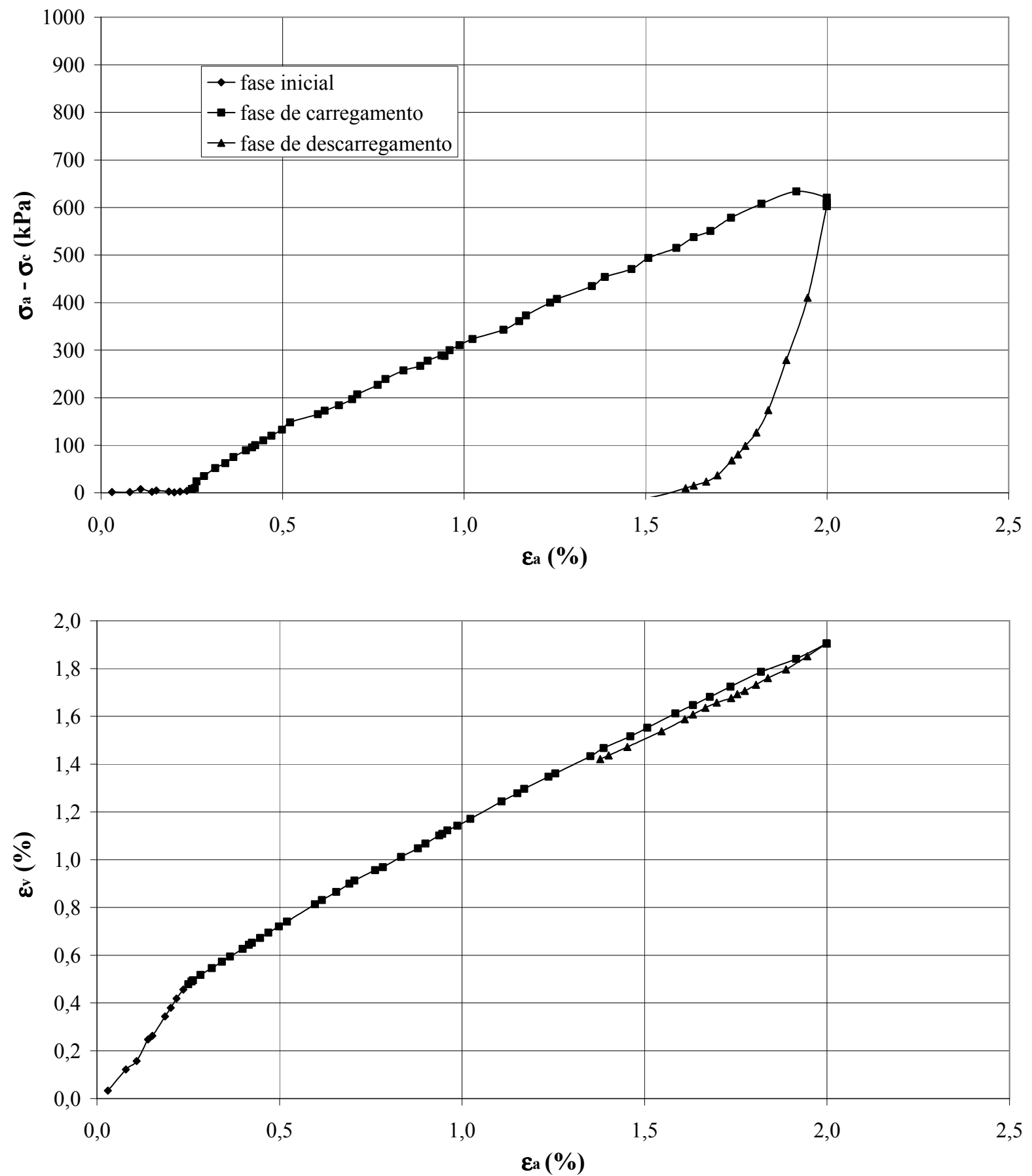

Figura 32. Relação tensão-deformação do ensaio triaxial convencional para tensão confinante de $100 \mathrm{kPa}$. 

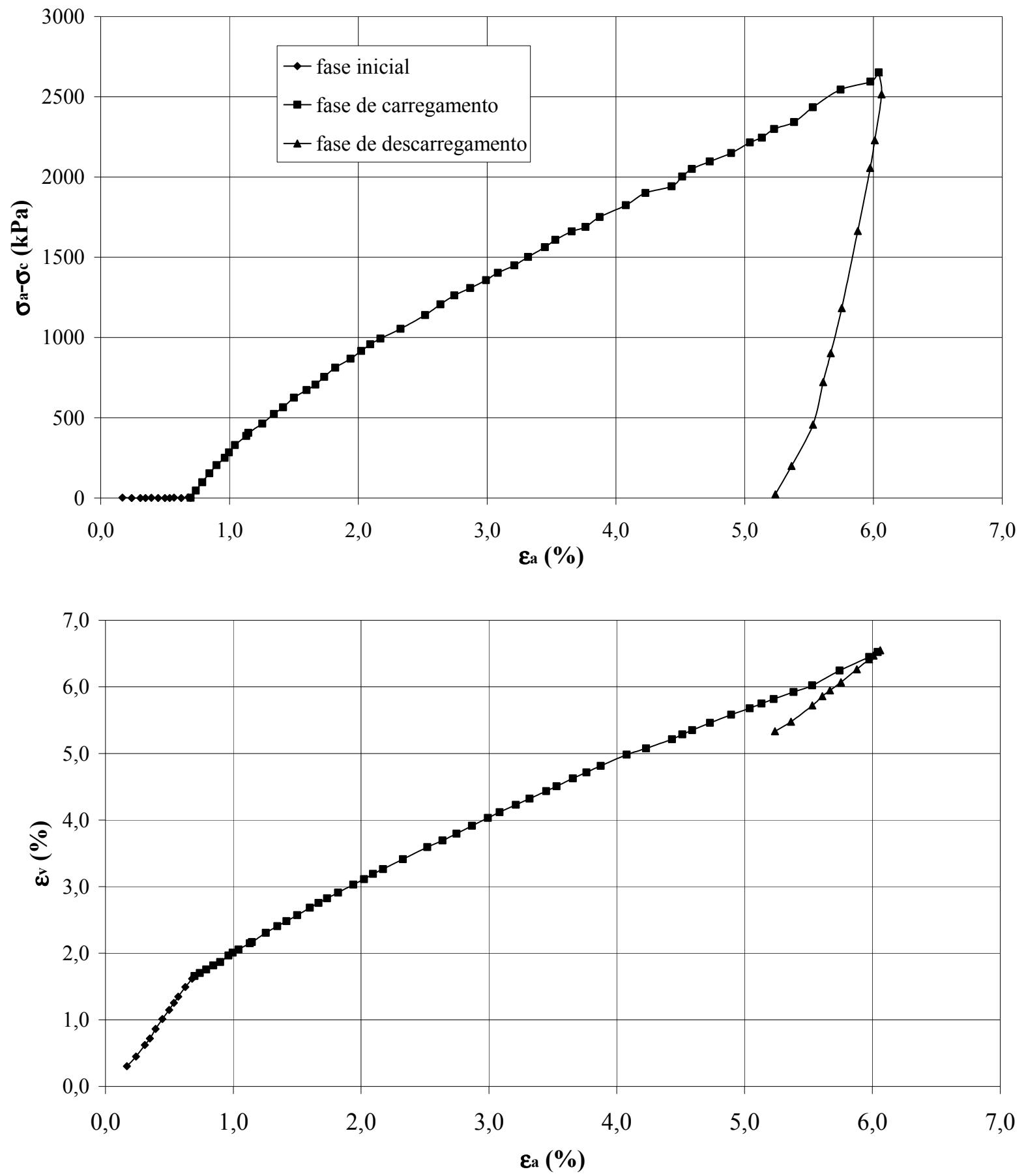

Figura 33. Relação tensão-deformação do ensaio triaxial convencional para tensão confinante de $500 \mathrm{kPa}$. 

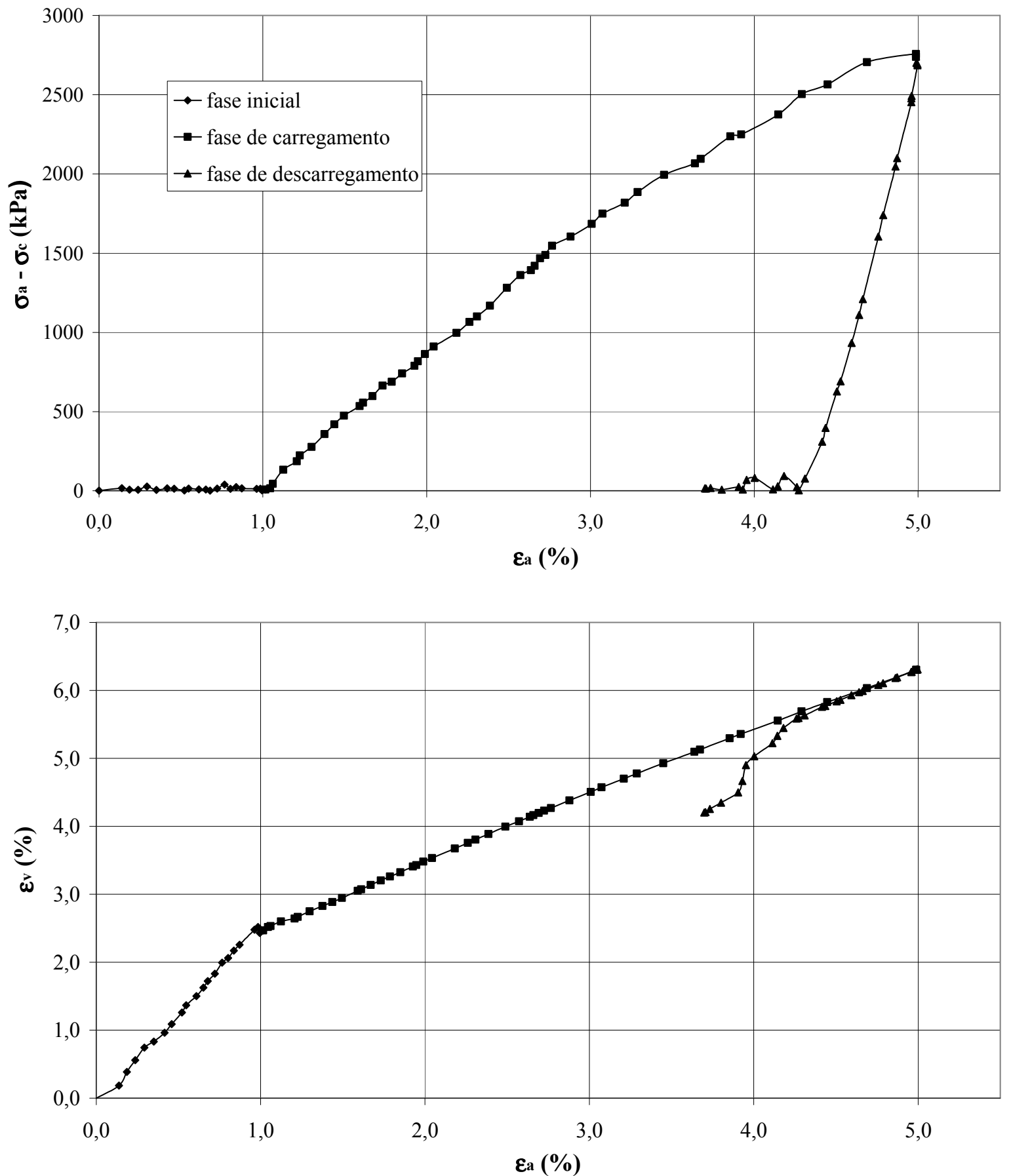

Figura 34. Relação tensão-deformação do ensaio triaxial convencional para tensão confinante de $1000 \mathrm{kPa}$. 
Primeiramente, observa-se que a deformação volumétrica específica sofrida durante a fase de carregamento difere da fase de confinamento. A fase inicial se caracteriza por um carregamento do tipo hidrostático e as deformações são de compressão (positivas) nas 3 direções. Ao aplicar a tensão desviadora, nota-se que a variação da deformação volumétrica específica para os 3 ensaios realizados decai em relação à deformação axial específica, pois as deformações horizontais passam a ser de expansão (negativas), ou seja, a amostra tende a se comprimir sob um estado triplo de tensões, resultando em uma abertura das faces laterais da amostra.

Os índices de quebra $B_{g}$ para os ensaios de carregamento convencional com tensões confinantes de 100,500 e $1000 \mathrm{kPa}$ foram respectivamente de 3,84, 5,08 e 5,13.

As curvas de carregamento resultantes dos ensaios convencionais mostram que o comportamento de deformação do material se aproxima da linearidade até a carga limite para todos os níveis de confinamento. O descarregamento, ao final do ensaio, caracteriza a não recuperação das deformações sofridas pelas amostras.

Para comparar as tensões limites de carregamento em relação a ruptura, apresenta-se na figura 35 os círculos de Mohr referentes às máximas tensões desviadoras aplicadas nos ensaios convencionais, juntamente com a envoltória de resistência obtida no ensaio de cisalhamento direto. 


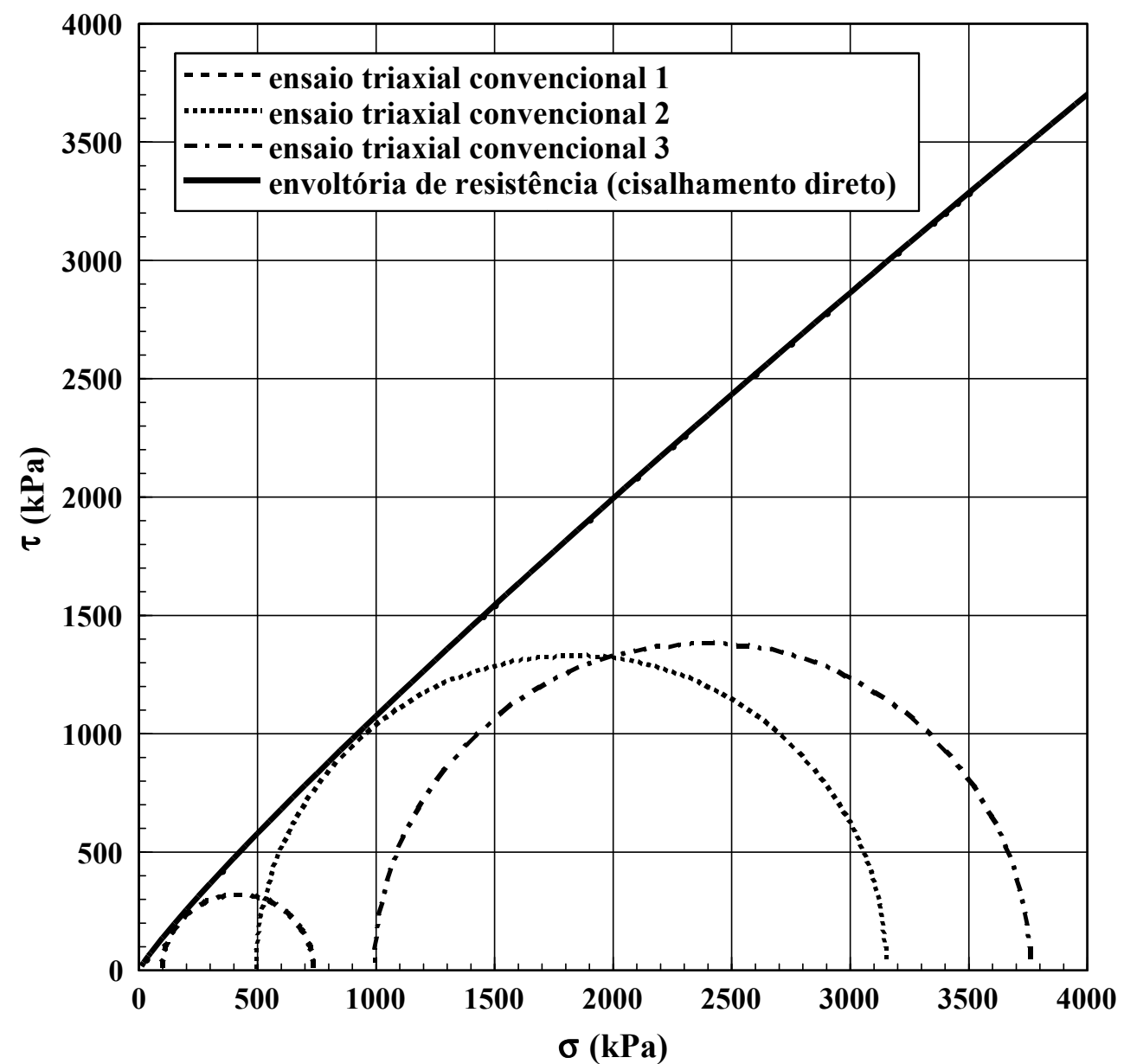

Figura 35. Circulo de Mohr para as tensões desviadoras aplicadas nos ensaios convencionais e envoltória de resistência do material obtida no ensaio de cisalhamento direto.

Verifica-se que o limite de carga para os ensaios triaxiais convencionais com baixas tensões confinantes (100 e $500 \mathrm{kPa}$ ) muito se aproximam da ruptura do ensaio de cisalhamento direto. Já a tensão desviadora limite para o ensaio com tensão confinante de $1000 \mathrm{kPa}$ está aquém da envoltória de resistência do ensaio de cisalhamento.

Na tentativa de se obter parâmetros de deformabilidade através do modelo hiperbólico, também foram obtidos os gráficos da transformada da curva tensão-deformação (Figura 36), como sugerido na Figura 58 do apêndice A, o qual possibilitaria fornecer o módulo de Young inicial e a tensão desviadora última. 


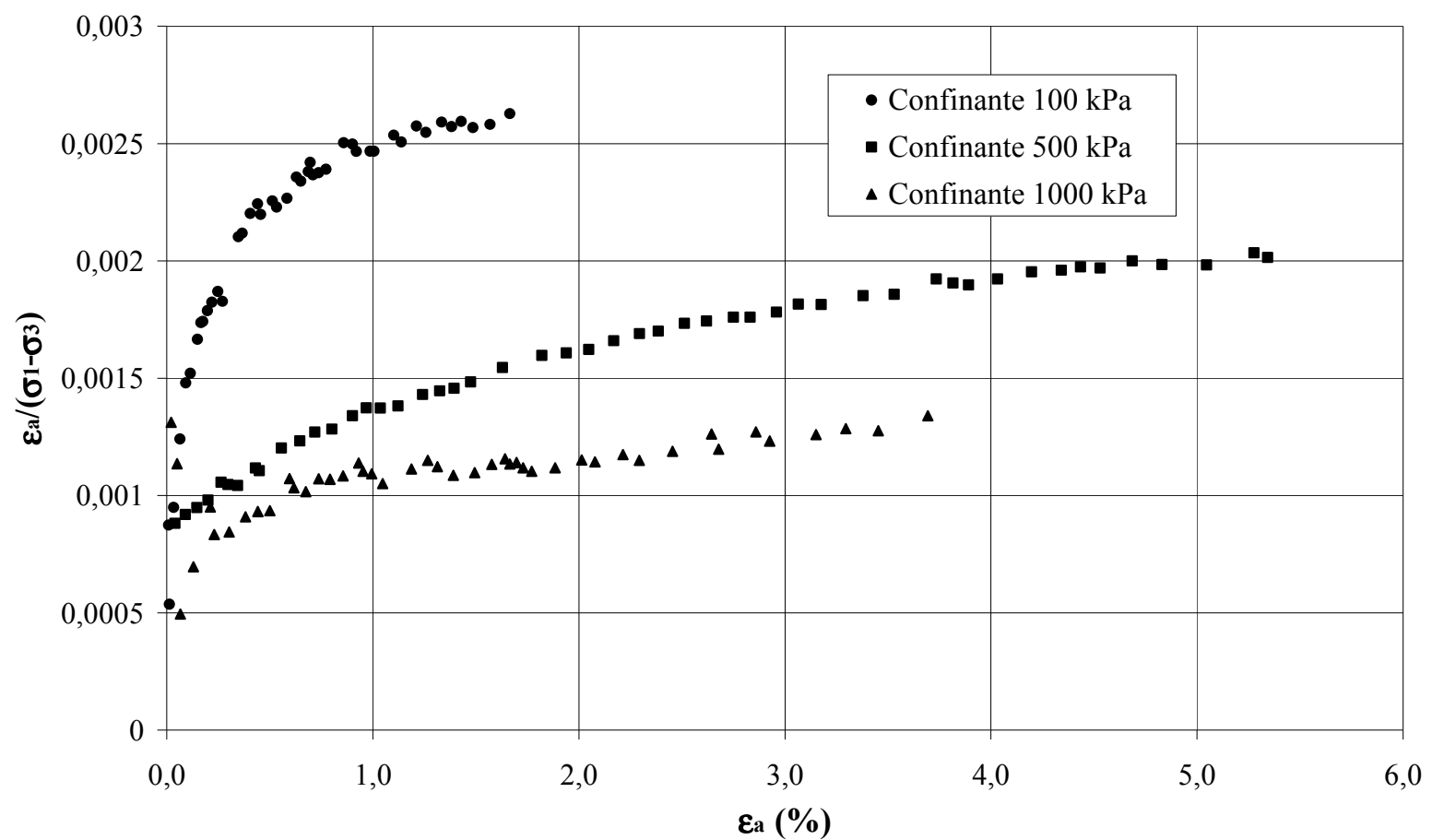

Figura 36. Transformada da tensão desviadora para interpretação de parâmetros através do modelo hiperbólico.

As curvas obtidas dos gráficos na Figura 36 não se aproximam de retas, tornando-se inadequado tentar interpretar os parâmetros de deformabilidade através do modelo hiperbólico.

A fim de avaliar melhor a rigidez do material durante a fase de carregamento, procurou-se obter valores de módulos secantes referentes às deformações axiais para as tensões de confinamento de 100, 500 e 1000 kPa (Figura 37). Na Figura 38 é esboçado um gráfico comparativo da variação da rigidez inicial e rigidez média com o confinamento. 


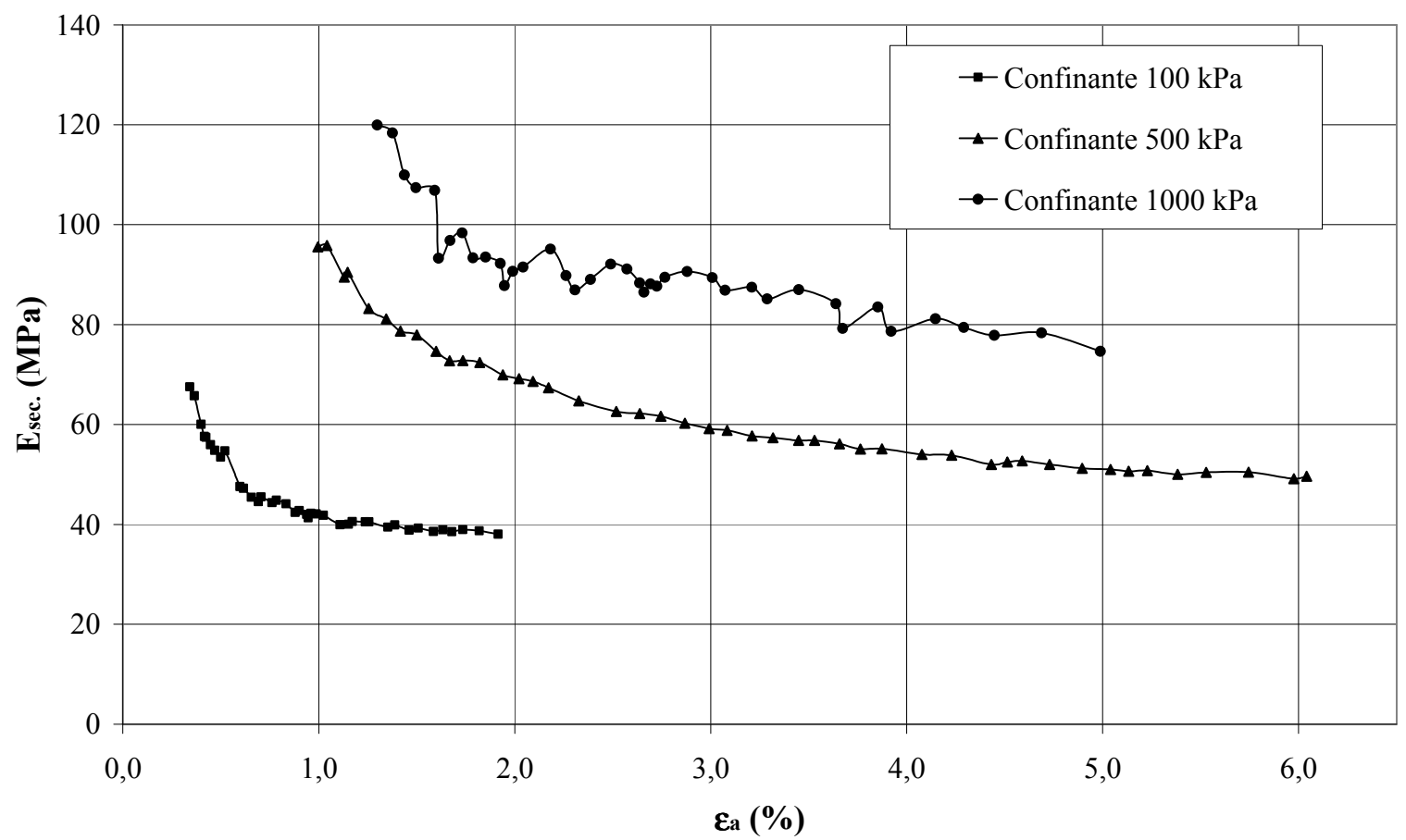

Figura 37. Módulos de deformabilidade axiais referentes aos ensaios triaxiais convencionais.

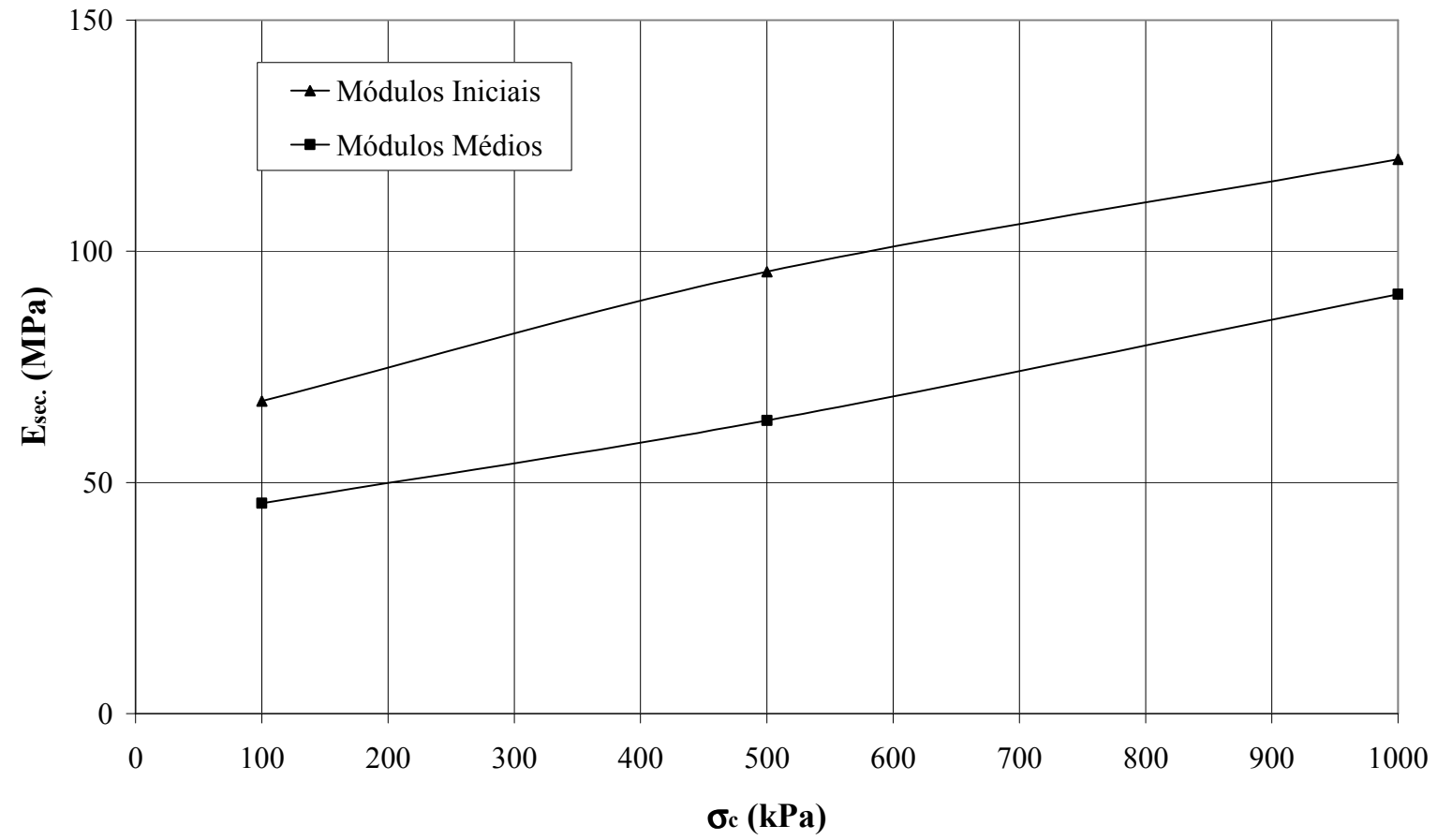

Figura 38. Variação dos módulos axiais iniciais e médios com a tensão confinante referente aos ensaios convencionais. 
Os resultados da figura 37 mostram que os módulos no início do carregamento são ligeiramente maiores do que para o restante do processo de carregamento onde se observam pequenos decréscimos de rigidez.

O fato de a amostra perder rigidez durante o início do carregamento pode estar relacionado com o fenômeno de esmagamento dos cantos e quebra dos grãos, dando origem a maiores áreas de contato grão a grão, aumentando, assim, a resistência à ruptura das partículas de rocha após uma determinada fase de carregamento, a partir da qual não há mais decréscimo da rigidez.

O gráfico da Figura 38 evidencia, como esperado, o aumento dos valores dos módulos para maiores níveis de tensões confinantes. O confinamento inicial aumenta a interação grão a grão, propiciando menores índices de vazios, reduzindo, assim, a capacidade de deformação do material, talvez devido ao rearranjo estrutural intergranular.

Seguindo a programação de ensaios pré-definida, foram realizados ensaios de carregamento com ciclos de descarregamento e recarregamento da tensão desviadora, mantendo a tensão confinante constante. Os ciclos foram realizados no momento em que a tensão axial era de 2 e 3,5 vezes maior que a tensão confinante.

As deformações axiais e volumétricas que se procederam durante o processo de carregamento e no ciclo de descarga e recarga, para as diferentes tensões confinantes, estão apresentadas nas Figuras 39 e 40. 

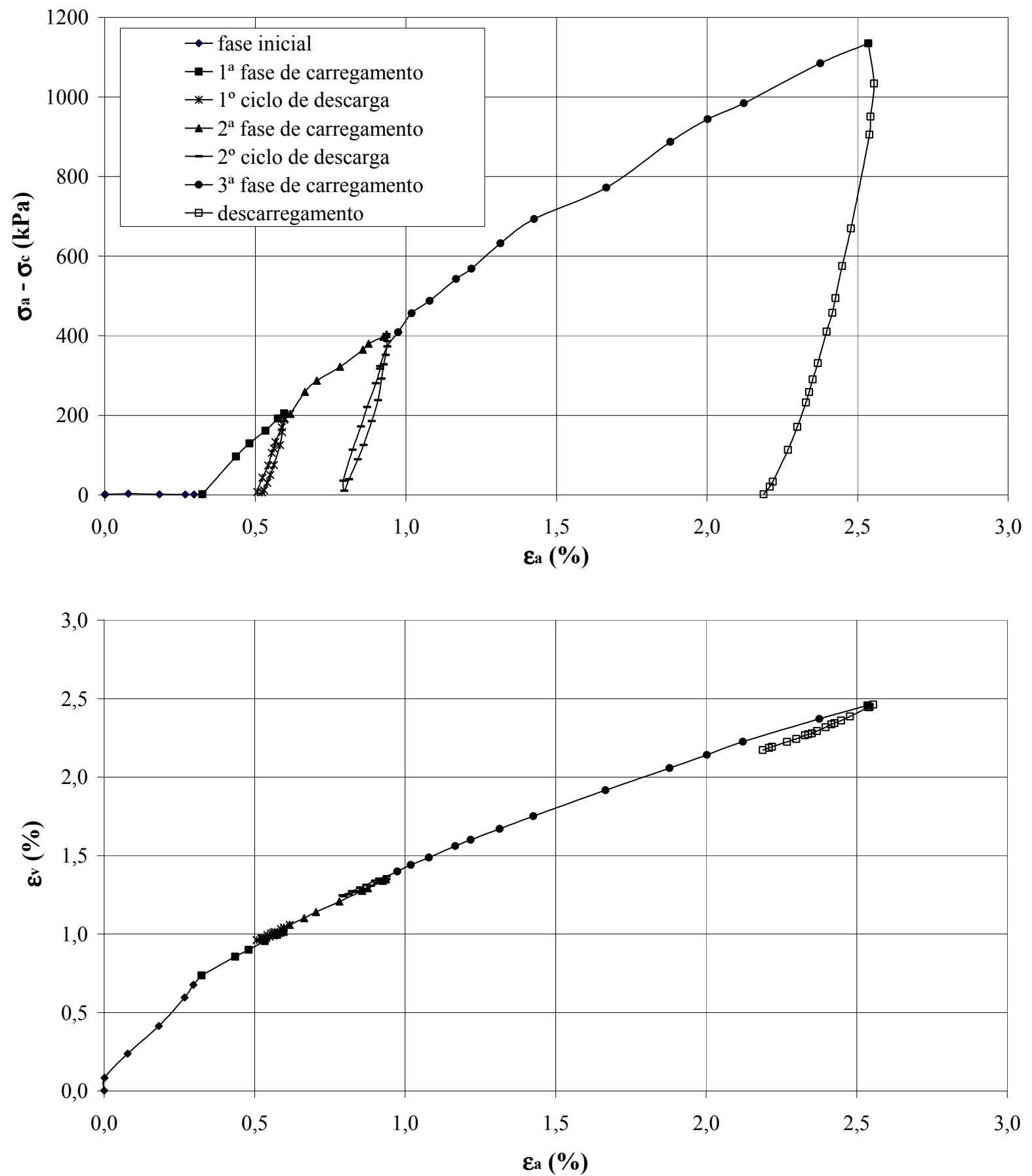

Figura 39. Relação tensão-deformação do ensaio triaxial de descarregamento para tensão confinante de $200 \mathrm{kPa}$. 

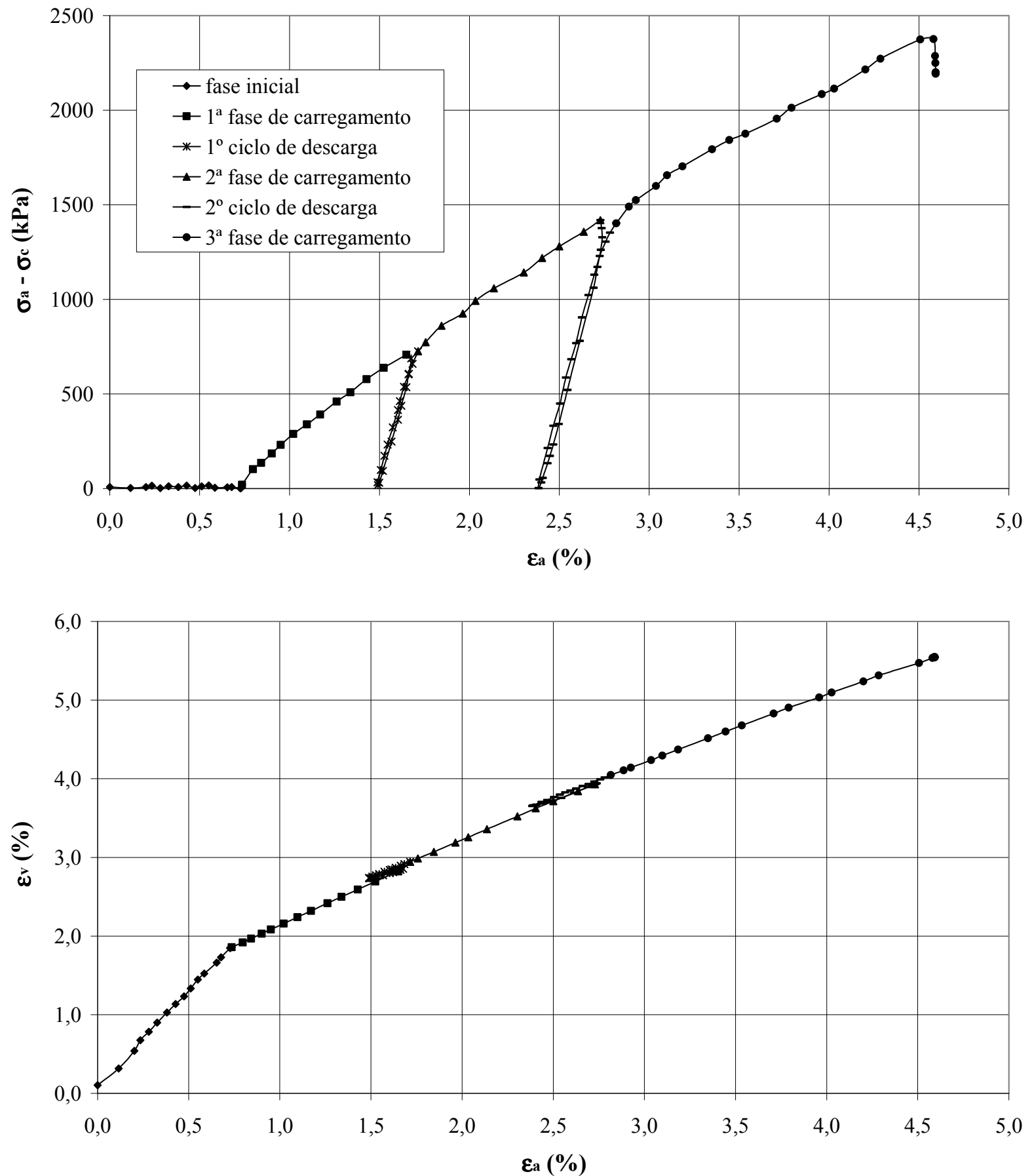

Figura 40. Relação tensão-deformação do ensaio triaxial de descarregamento para tensão confinante de $700 \mathrm{kPa}$. 
Os ensaios de carregamento com ciclos de descarga e recarga mostram que o material granular apresenta características clássicas de material plástico com deformações específicas muito pequenas de recuperação quando sujeito ao descarregamento. Nota-se claramente que, tanto na descarga quanto na recarga, as curvas indicam inclinações semelhantes, apresentando uma maior rigidez quando comparada à fase de carregamento.

Os índices de quebra $B_{g}$ para os ensaios de carregamento com descarregamento para tensões confinantes de 200 e $700 \mathrm{kPa}$ foram respectivamente de 3,89 e 4,02.

As Figuras 41 e 42 apresentam os resultados referentes aos módulos de deformabilidade durante a fase de carregamento e no ciclo de descarga-recarga para as duas condições de confinamento.

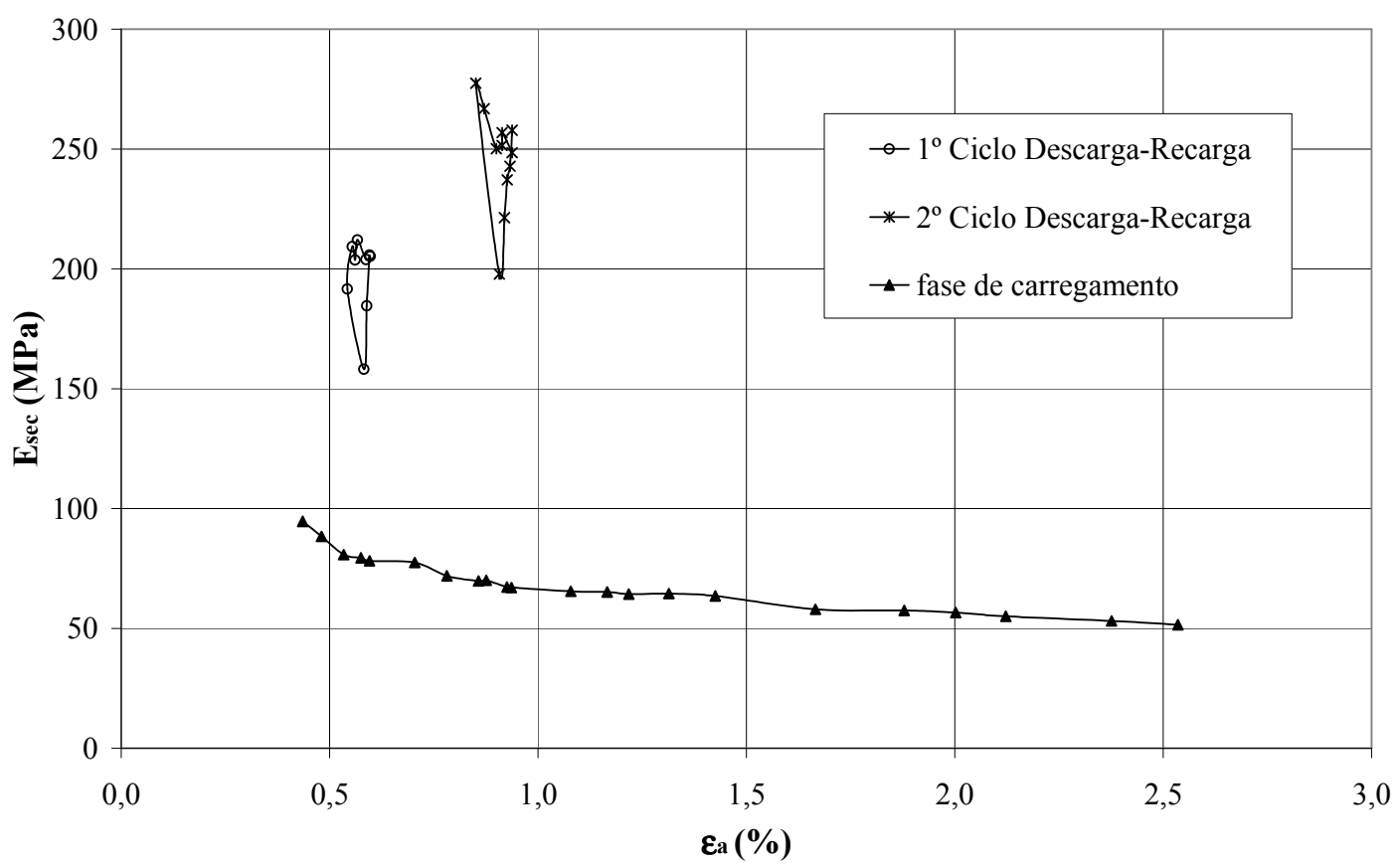

Figura 41. Módulos de deformabilidade axiais referentes ao ensaio triaxial de descarregamento para tensão confinante de $200 \mathrm{kPa}$. 


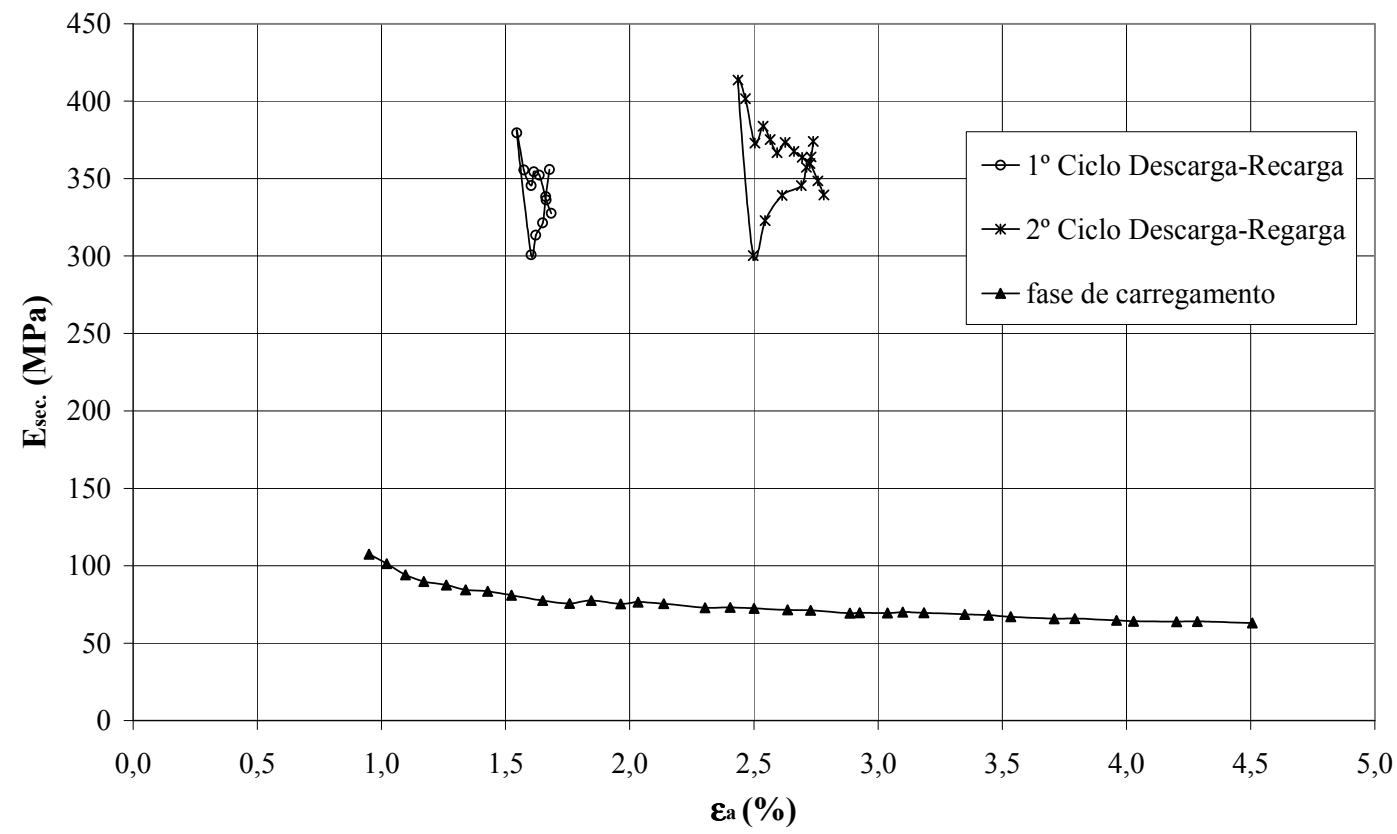

Figura 42. Módulos de deformabilidade axiais referentes ao ensaio triaxial de descarregamento para tensão confinante de $700 \mathrm{kPa}$.

Os resultados das Figuras 41 e 42 mostram que os módulos, durante os ciclos de descargarecarga, são em média 3 a 5 vezes superiores aos módulos de carregamento. Verifica-se, principalmente para tensão confinante de $200 \mathrm{kPa}$, que há uma ligeira diferença nos módulos entre os 2 ciclos de descarga realizados. Ao comparar as relações de módulos entre os ciclos e a fase de carregamento para as diferentes tensões confinantes, verifica-se que o maior confinamento proporciona maior diferença entre os módulos.

Grande parte das deformações específicas durante a fase de carregamento é decorrente do rearranjo e esmagamento de cantos entre grãos, conforme citado anteriormente. Ao descarregar as tensões atuantes, os grãos não retornam às posições originais, restando apenas uma pequena parcela de deformação elástica da rocha no contato grão a grão. Isso pode estar diretamente relacionado às pequenas deformações de recuperação quando do descarregamento e ao ganho de rigidez na recarga.

O gráfico apresentado na Figura 43 refere-se ao ensaio de carregamento isotrópico, ou seja, carregamento de igual valor nos 3 diferentes planos até um estado de tensão limite de carga do 
equipamento. Na Figura 44, é mostrada uma curva derivada da relação tensão-deformação do ensaio isotrópico que representa os módulos tangentes no processo de carregamento.

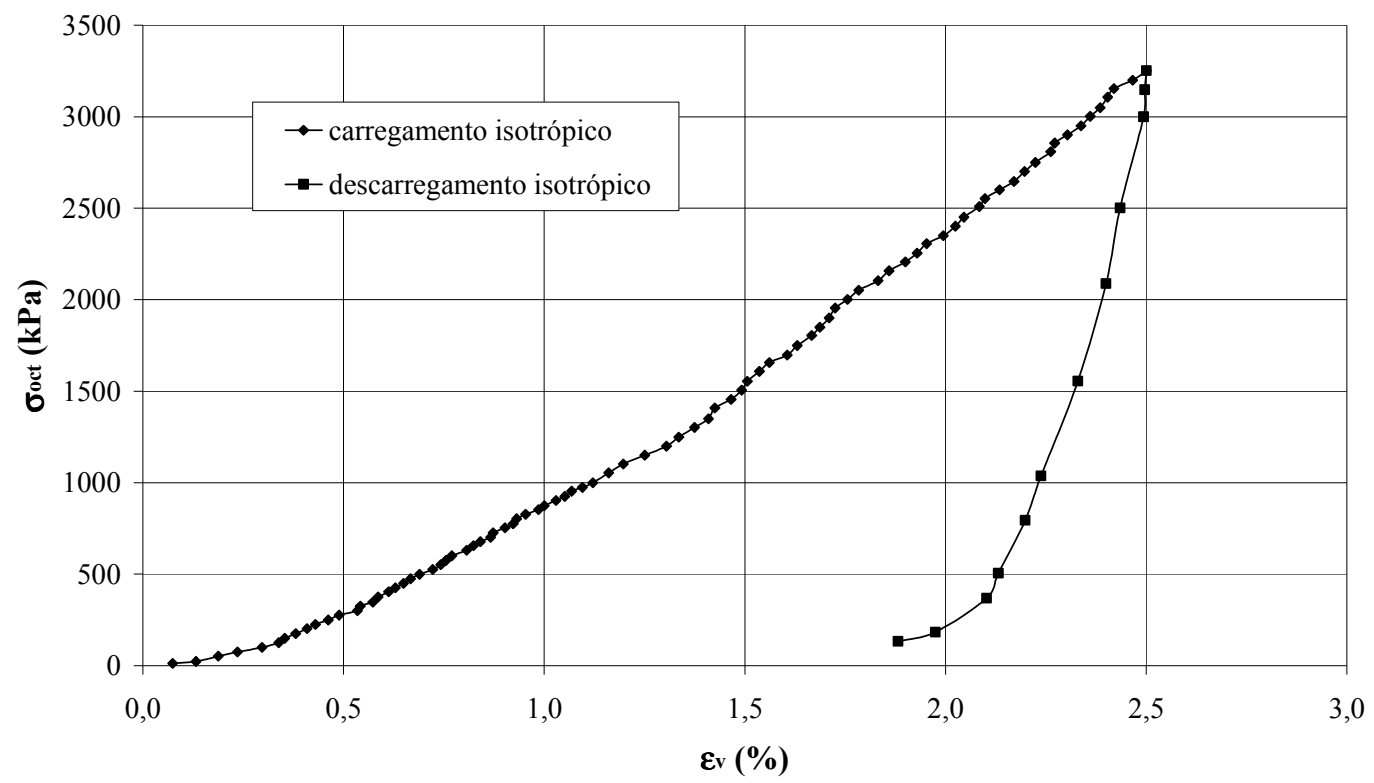

Figura 43. Relação tensão-deformação referente ao ensaio isotrópico.

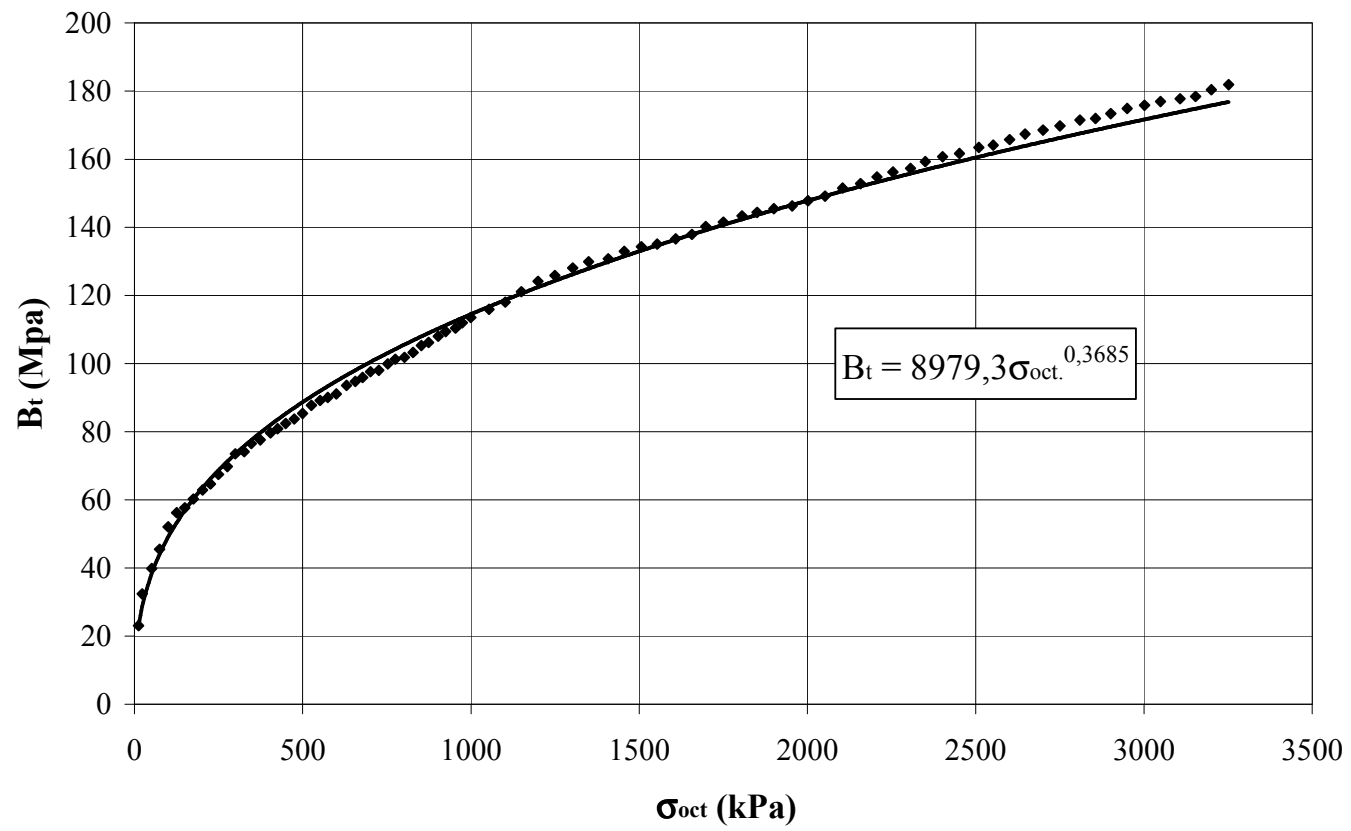

Figura 44. Variação do módulo de deformabilidade volumétrico com a tensão octaédrica referente ao ensaio isotrópico. 
O ensaio isotrópico clássico apresenta sempre um acréscimo do módulo de deformabilidade à medida que a tensão octaédrica aumenta de valor. Isso se deve ao fato de que o índice de vazios diminui durante o processo de carregamento e os espaços para os grãos se agruparem tornam-se limitados. Os índices de quebra $B_{g}$ para o ensaio isotrópico foi de 2,34.

A relação entre o ganho de rigidez e o aumento do estado de confinamento aproxima-se da hipérbole representada pela equação indicada na Figura 44.

Os ensaios chamados de transversais também foram realizados baseados na programação de carga referida no item 6.1.2. Procurou-se adequar o carregamento à situação de inversão da tensão principal maior, ou seja, inicialmente aplicou-se uma tensão desviadora onde as tensões laterais de confinamento são superiores à tensão axial. Em seguida, aplicou-se um carregamento axial em uma proporção maior do que a tensão de confinamento, até atingir a situação onde a carga axial se iguala às tensões laterais, caracterizando o "alívio" de tensão desviadora. O processo chamado de recarga é aquele onde a tensão axial passa a ser maior que as tensões laterais até atingir um valor de desviadora correspondente à fase inicial do processo. A partir daí, o carregamento da tensão desviadora se procede sobre a mesma trajetória até atingir a ruptura. É importante notar que, mesmo com o chamado "alívio da desviadora", sempre há um acréscimo das tensões nos 3 planos, aumentando continuamente o estado de tensão da amostra.

A Figura 45 apresenta as trajetórias de tensões executadas nos ensaios transversais para os 3 diferentes níveis de confinamento. Os gráficos das Figuras 46 a 54 apresentam, respectivamente, as deformações volumétricas, axiais e laterais durante todo o processo de carregamento transversal para os níveis de confinamento de 200, 500 e $1000 \mathrm{kPa}$. 


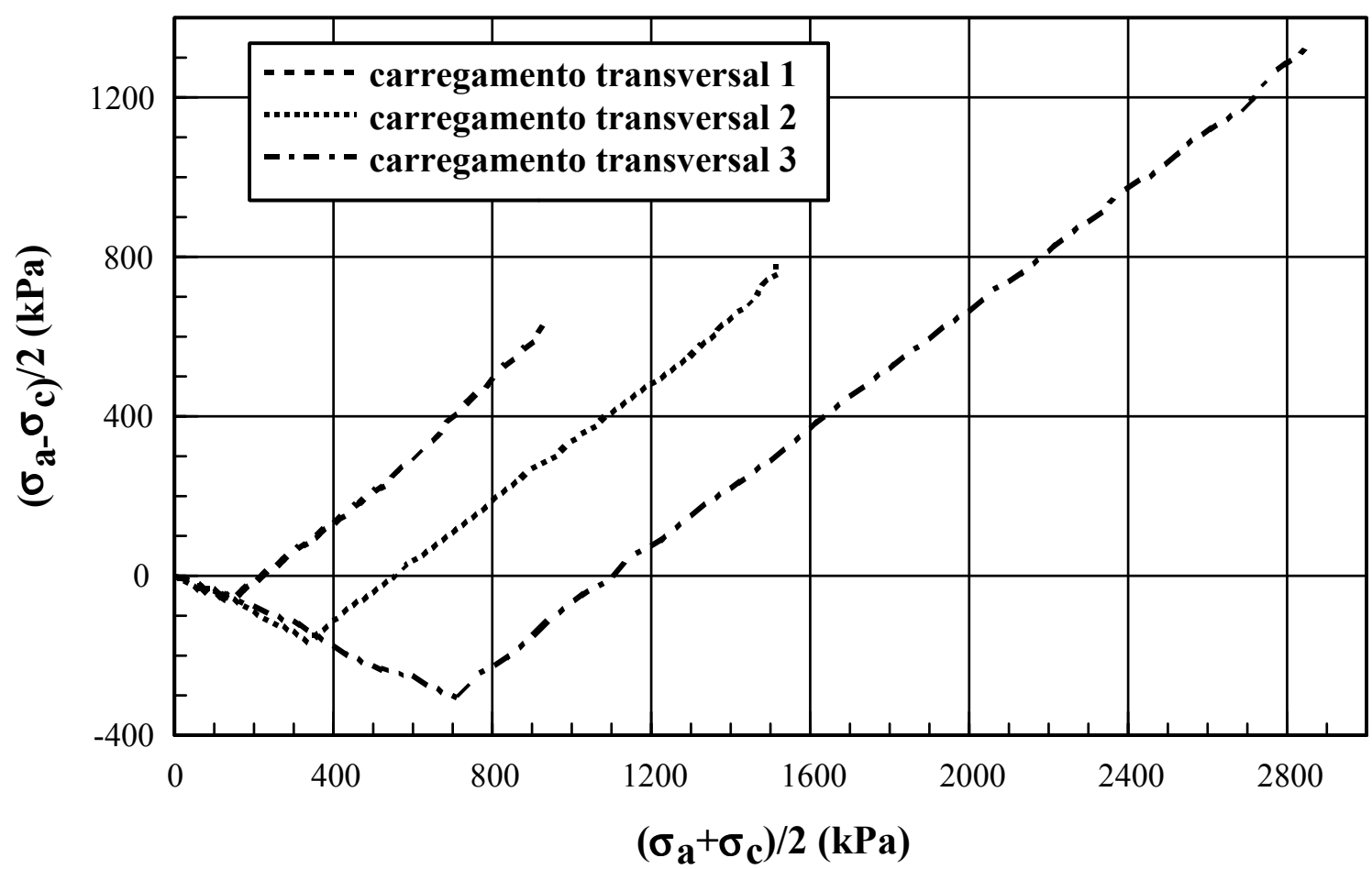

Figura 45. Trajetórias de tensões executadas nos ensaios triaxiais transversais.

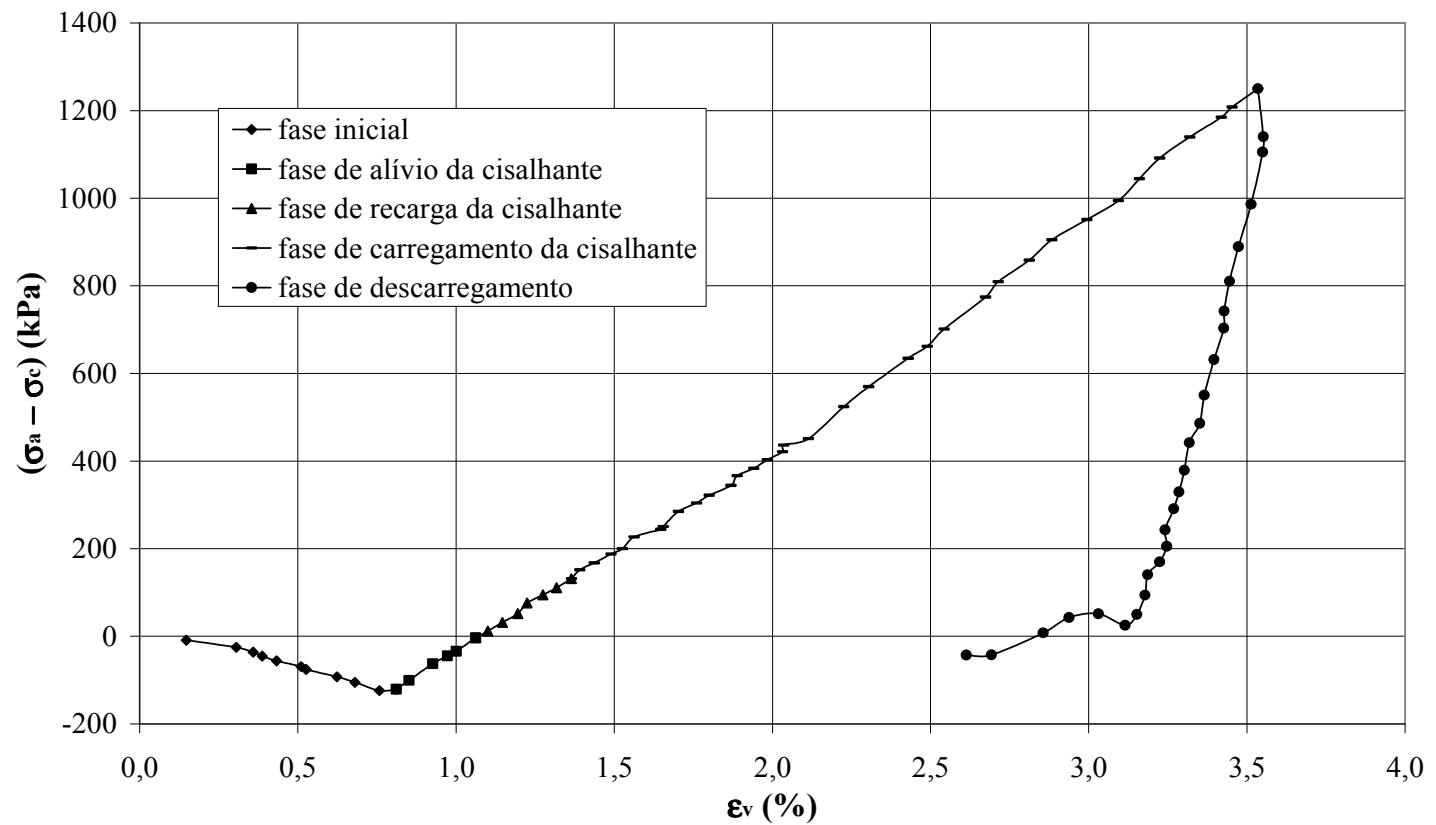

Figura 46. Relação tensão-deformação volumétrica referente ao ensaio triaxial transversal para tensão confinante inicial de $200 \mathrm{kPa}$. 


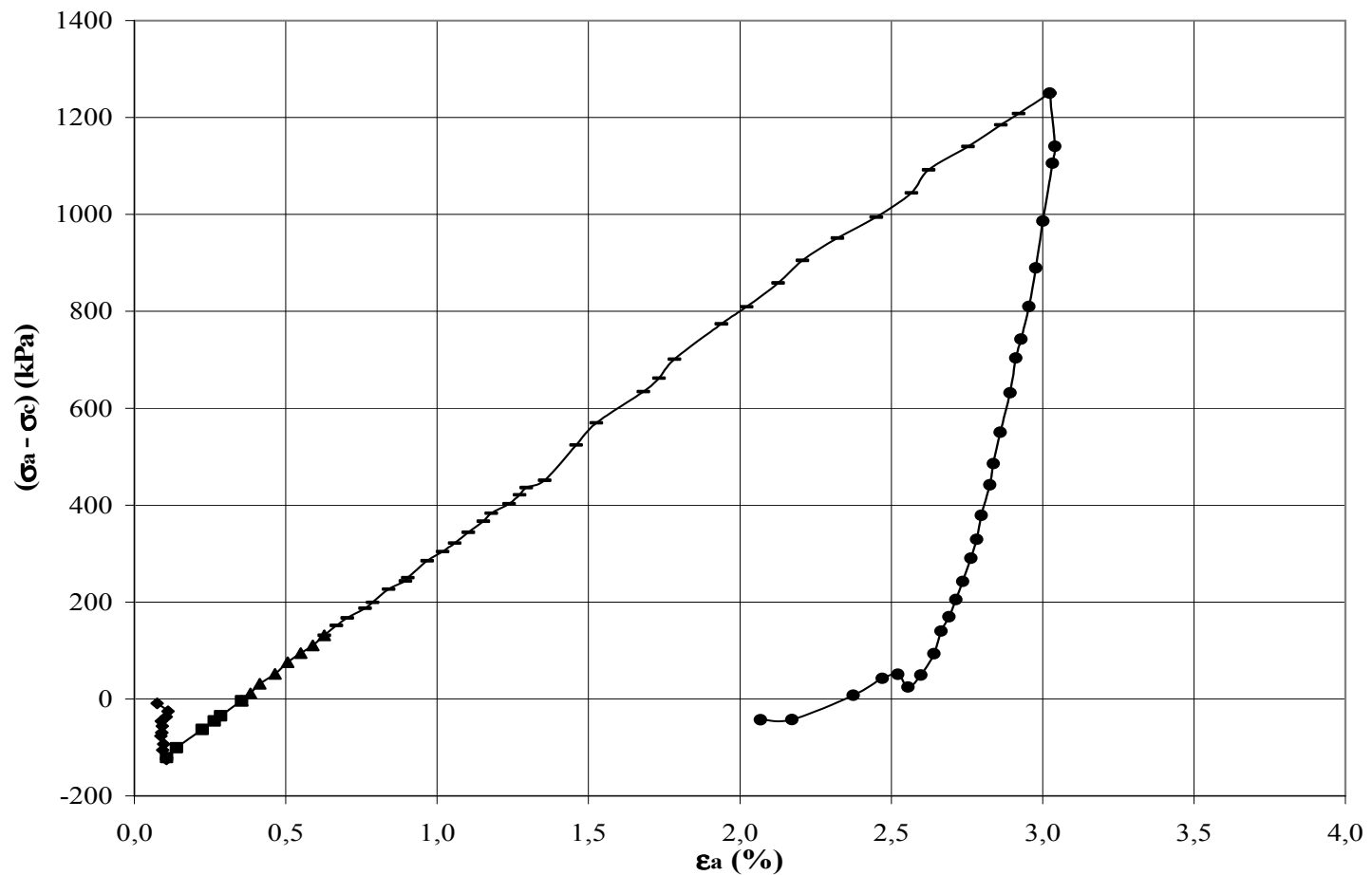

Figura 47. Relação tensão-deformação axial referente ao ensaio triaxial transversal para tensão confinante inicial de $200 \mathrm{kPa}$.

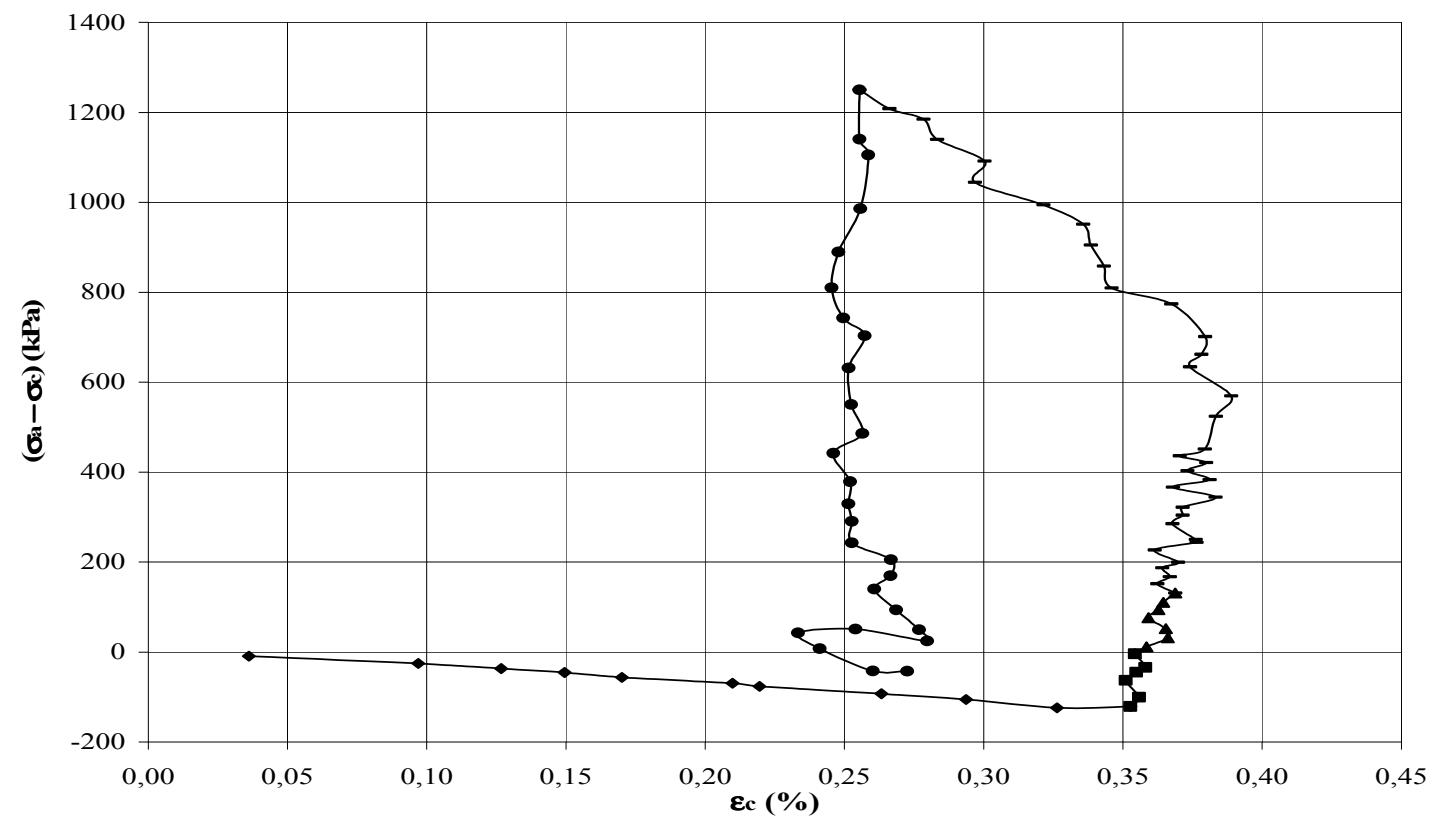

Figura 48. Relação tensão-deformação lateral referente ao ensaio triaxial transversal para tensão confinante inicial de $200 \mathrm{kPa}$. 


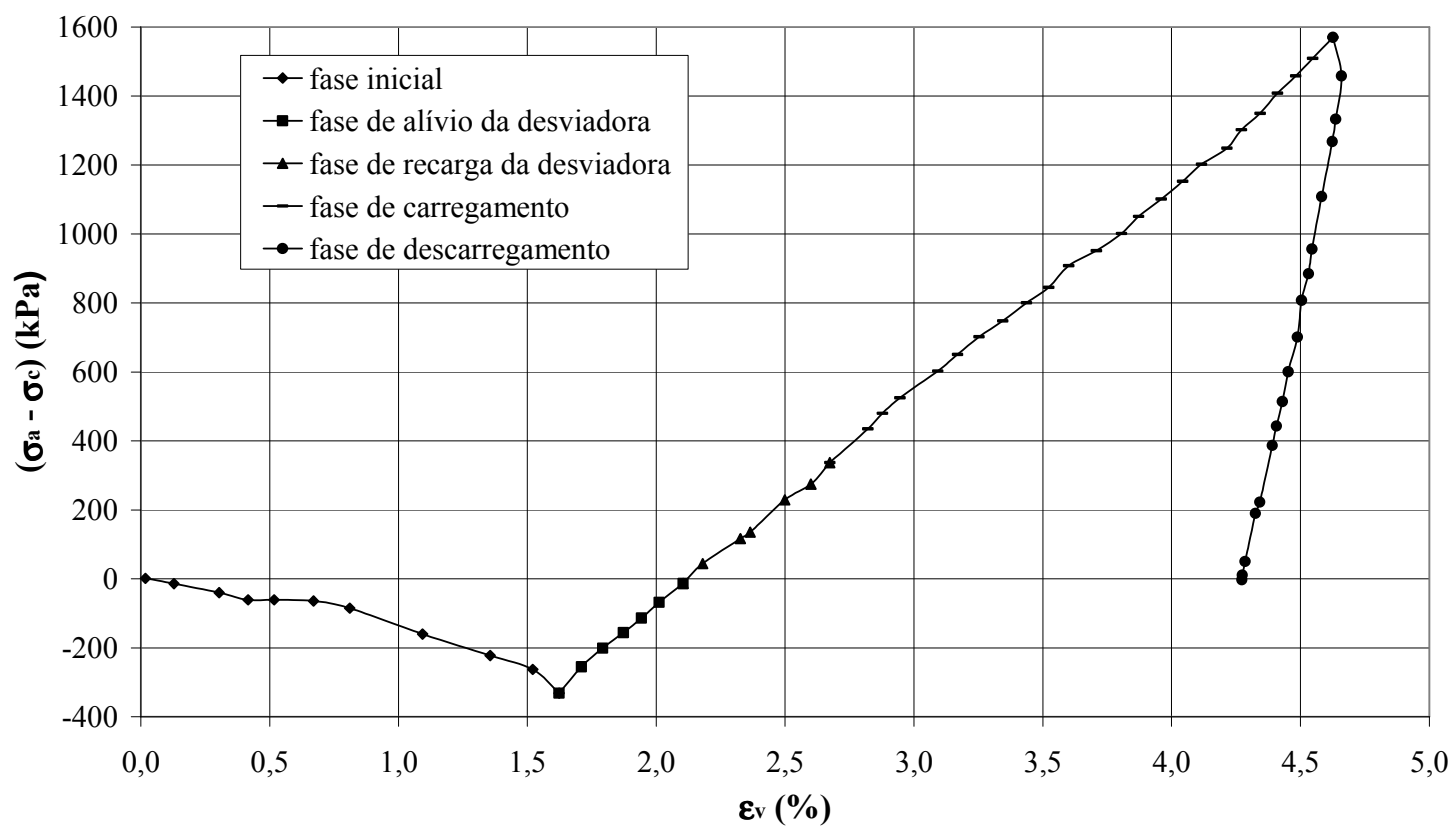

Figura 49. Relação tensão-deformação volumétrica referente ao ensaio triaxial transversal para tensão confinante inicial de $500 \mathrm{kPa}$.

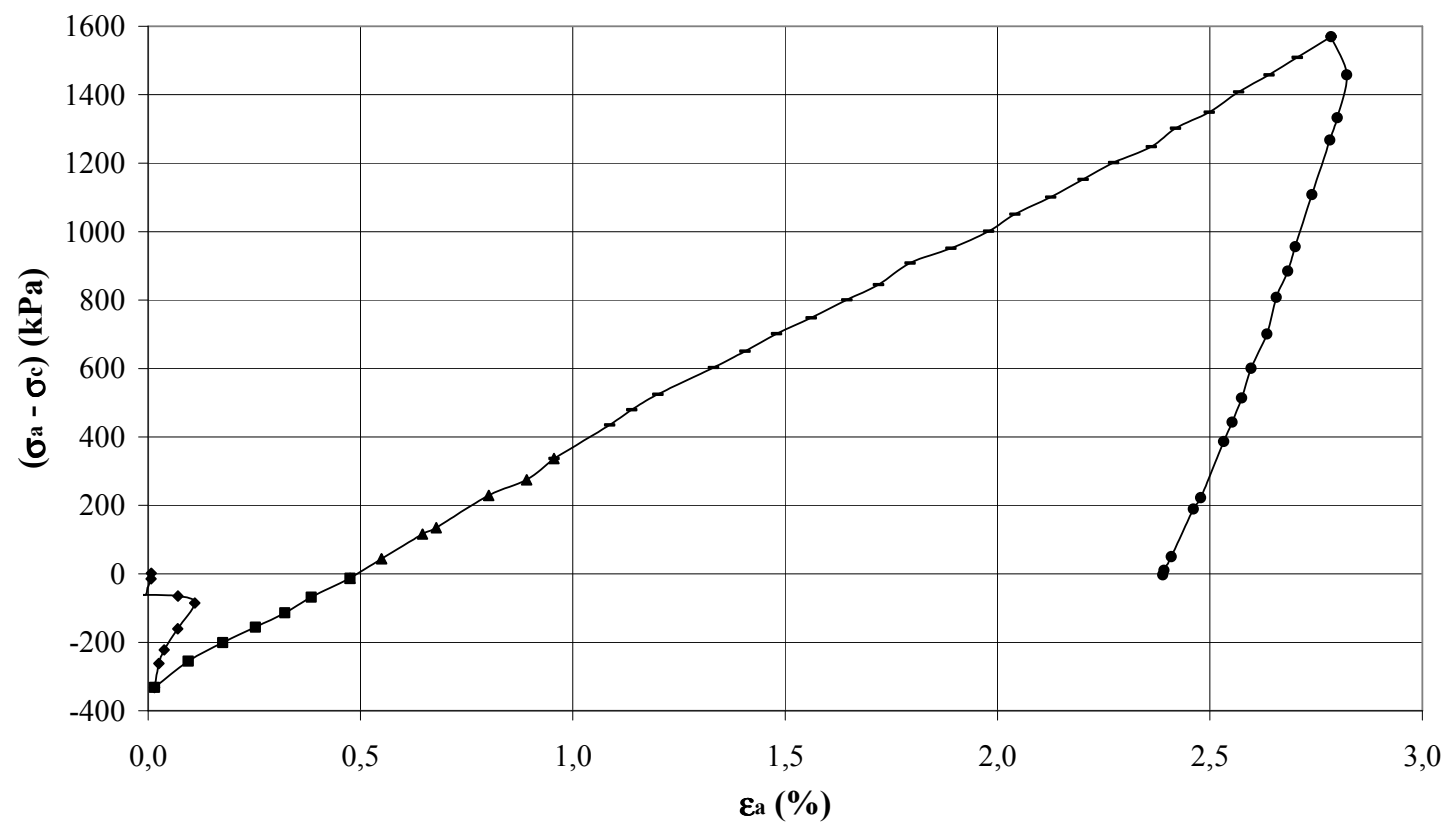

Figura 50. Relação tensão-deformação axial referente ao ensaio triaxial transversal para tensão confinante inicial de $500 \mathrm{kPa}$ 


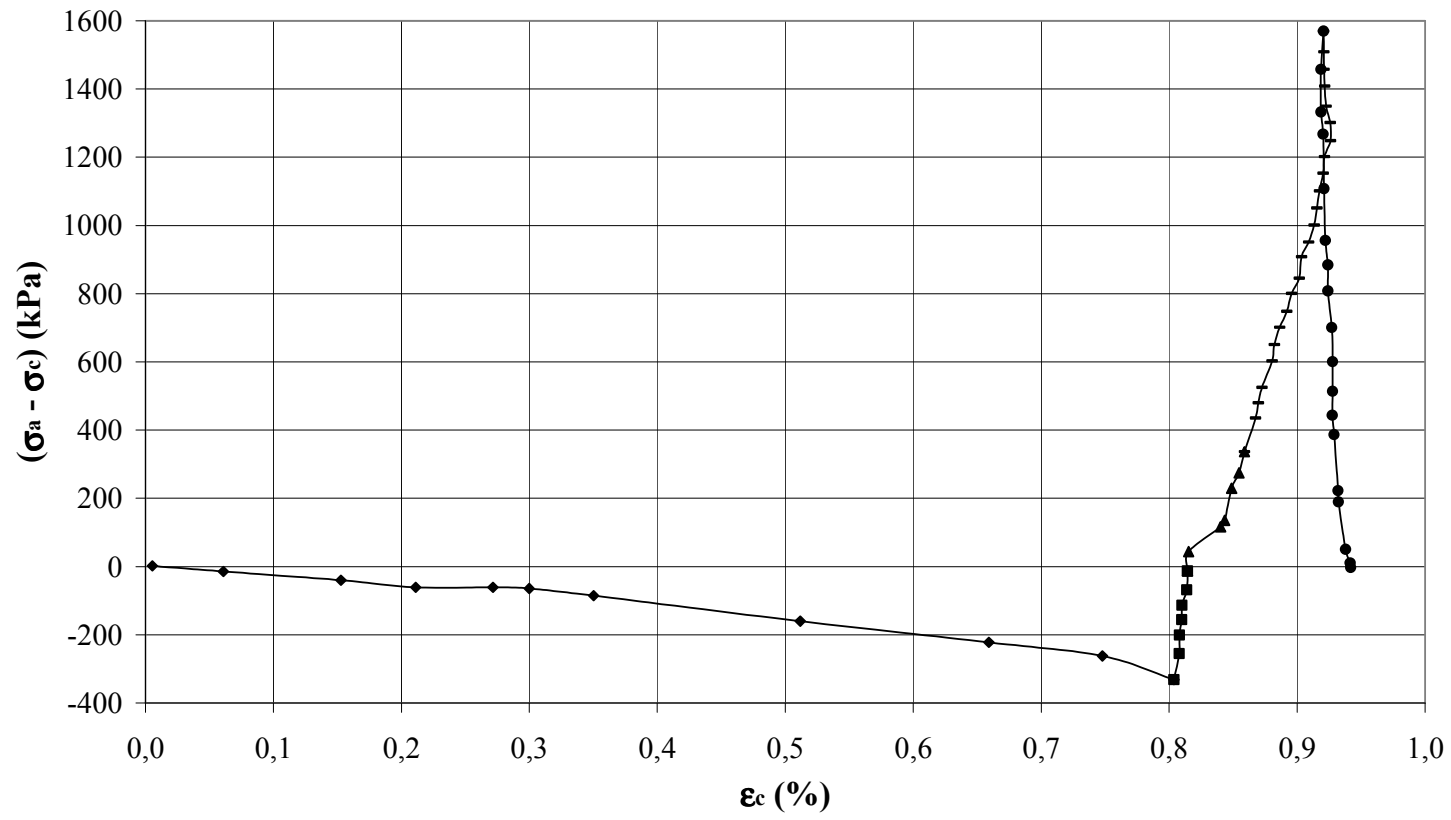

Figura 51. Relação tensão-deformação lateral referente ao ensaio triaxial transversal para tensão confinante inicial de $500 \mathrm{kPa}$

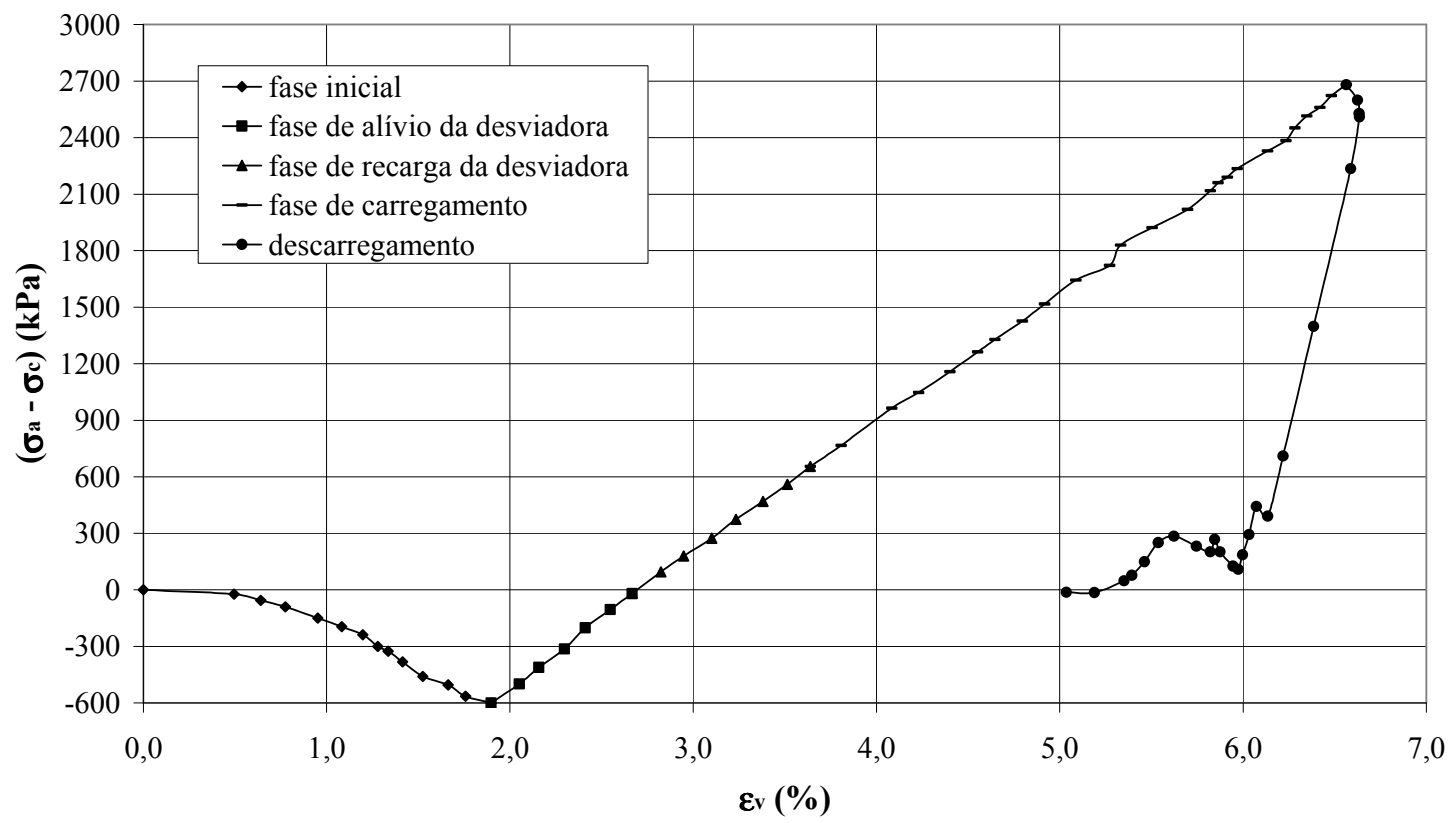

Figura 52. Relação tensão-deformação volumétrica referente ao ensaio triaxial transversal para tensão confinante inicial de $1000 \mathrm{kPa}$ 


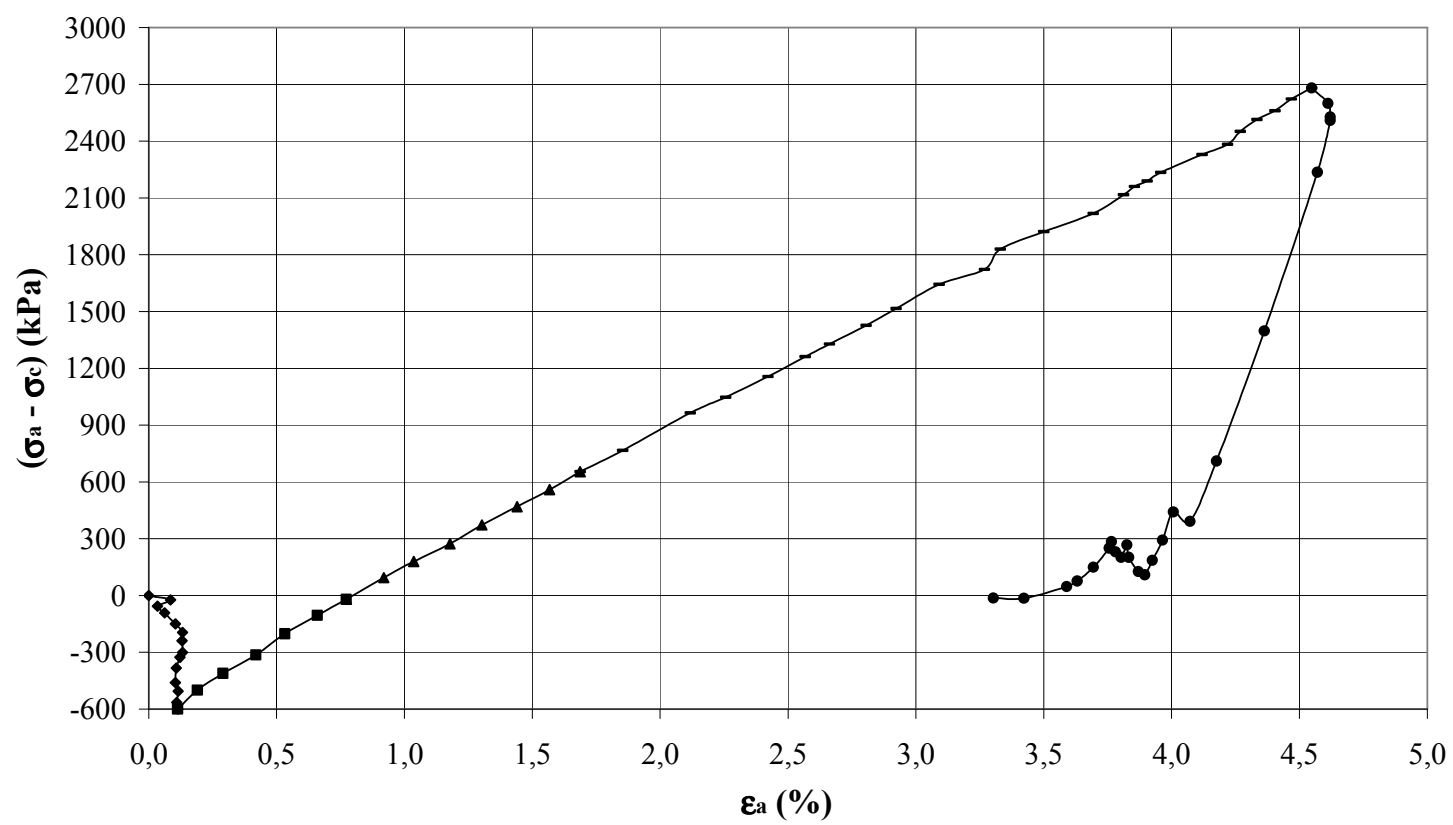

Figura 53. Relação tensão-deformação axial referente ao ensaio triaxial transversal para tensão confinante inicial de $1000 \mathrm{kPa}$

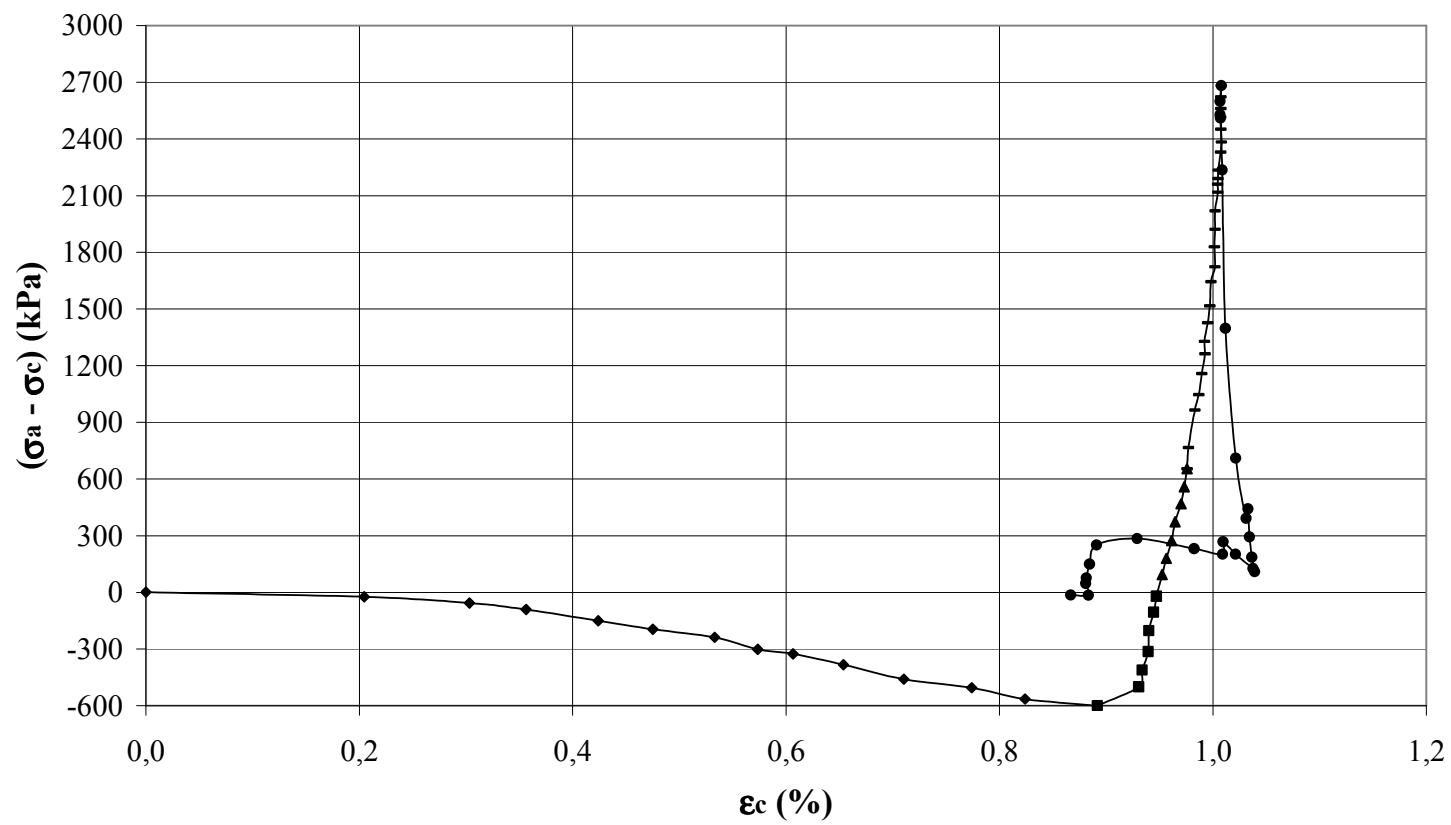

Figura 54. Relação tensão-deformação lateral referente ao ensaio triaxial transversal para tensão confinante inicial de $1000 \mathrm{kPa}$ 
As curvas de deformação volumétrica específica para os 3 ensaios de carregamento "transversal" apresentam uma certa similaridade quanto a sua forma. Aparentemente, as variações das deformações volumétricas durante a fase inicial são superiores às demais fases consideradas. Nota-se, também, que não há variações significativas da inclinação das curvas durante as fases de alívio, recarga e carregamento da tensão desviadora, resultando em uma invariabilidade de rigidez volumétrica nesse processo de carregamento. Em geral, a diferença entre as curvas para os 3 níveis de confinamento coincide basicamente na grandeza das deformações sofridas.

Os gráficos de deformação axial específica indicam quase que uma invariabilidade das deformações axiais durante a fase inicial do ensaio, já que nessa fase o acréscimo de carga axial é proporcionalmente menor ou inferior ao carregamento lateral. Após a fase inicial, as deformações axiais específicas predominam e seguem contínuas sobre uma mesma inclinação até o limite de carga.

Uma situação inversa à citada acima ocorre com as curvas de deformação lateral. Nestas, verificam-se que as deformações específicas positivas ocorrem principalmente na fase inicial. Nas demais fases, até o limite de carga, quase não há variação na sua magnitude. Uma particularidade ocorre no ensaio de menor confinamento, onde se observa que as variações das deformações específicas laterais são negativas até atingirem o limite de carga, ou seja, há uma abertura das faces laterais no final do carregamento.

Os índices de quebra $B_{g}$ para os ensaios de carregamento transversal com níveis de confinamento de 200,500 e $1000 \mathrm{kPa}$ foram respectivamente de 3,84, 4,42 e 4,86.

Para uma melhor interpretação dos dados nesse tipo de carregamento, tornou-se interessante extrair valores de módulos de deformabilidade através das deformações volumétricas, já que estas representam a soma algébrica das deformações nos 3 planos. Nos gráficos das Figuras 55, 56 e 57, estão apresentados os valores dos módulos volumétricos para as diferentes fases de carregamento em função da deformação volumétrica específica. 


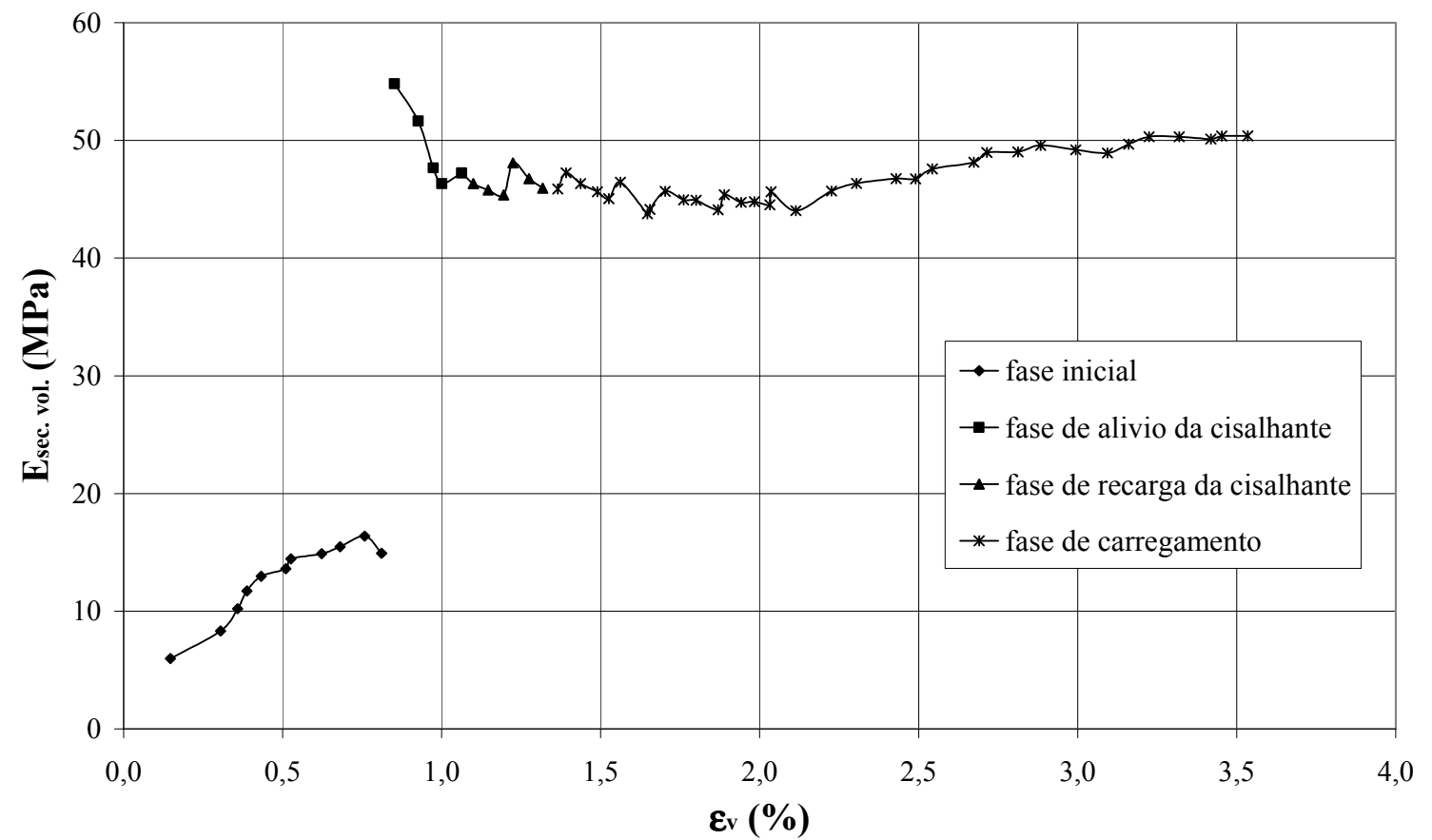

Figura 55. Módulos de deformabilidade volumétrico referentes ao ensaio triaxial transversal para tensão confinante inicial de $200 \mathrm{kPa}$

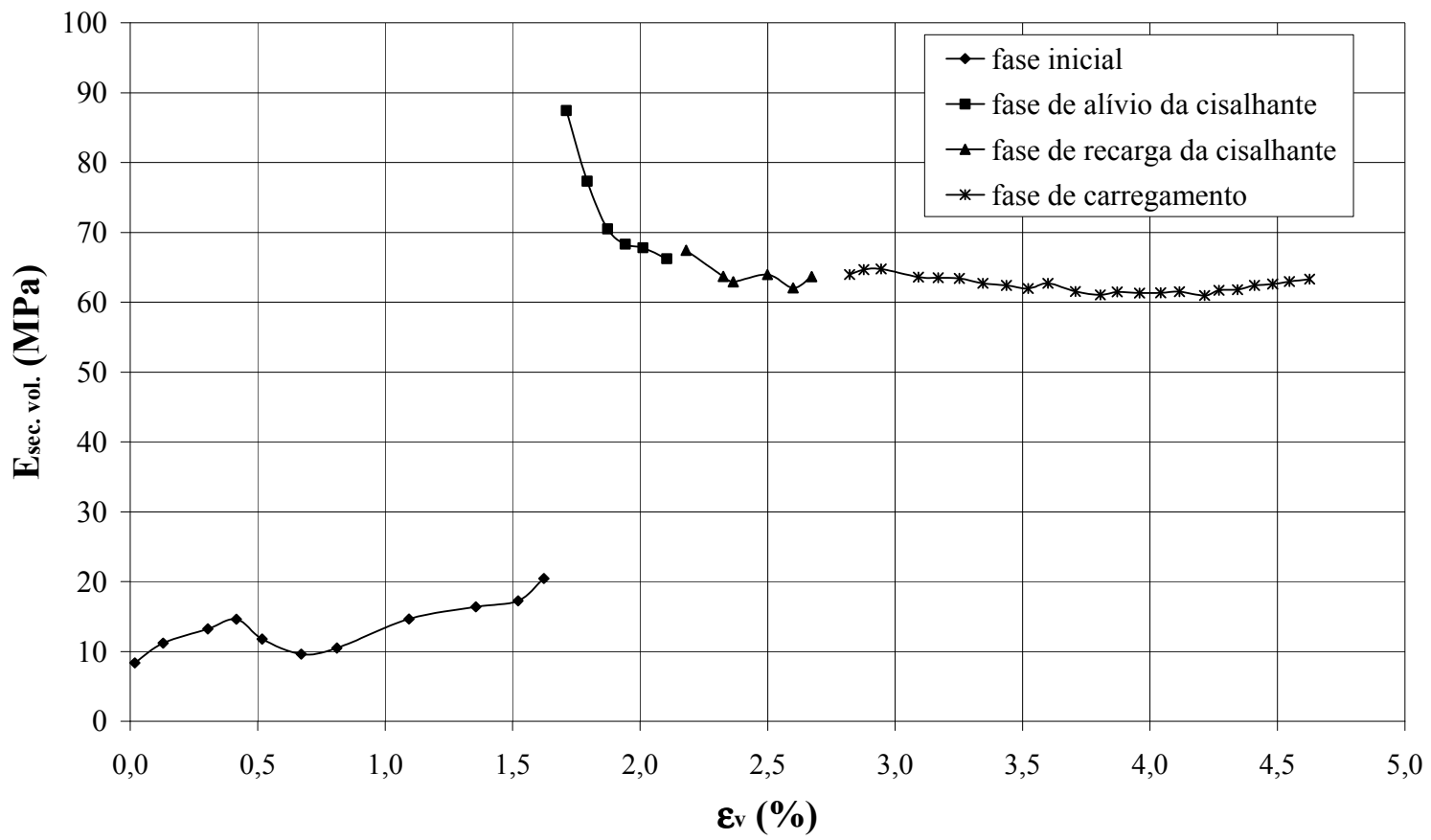

Figura 56. Módulos de deformabilidade volumétrico referentes ao ensaio triaxial transversal para tensão confinante inicial de $500 \mathrm{kPa}$ 


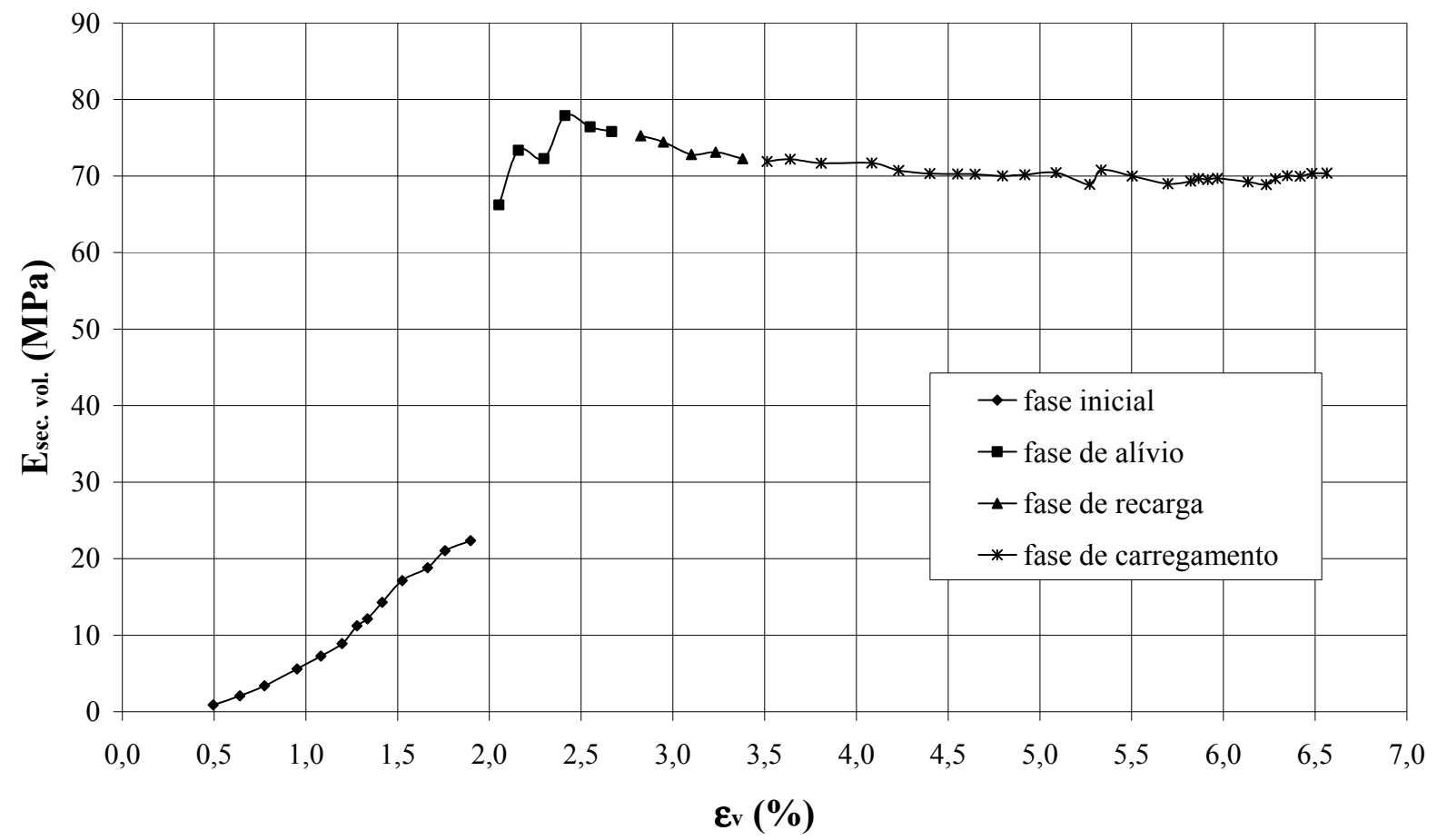

Figura 57. Módulos de deformabilidade volumétrico referentes ao ensaio triaxial transversal para tensão confinante inicial de $1000 \mathrm{kPa}$

Para o nível de confinamento entre 200 e $300 \mathrm{kPa}$ verifica-se que a rigidez durante a fase inicial é, em média, 3,5 vezes menor que as demais fases de carregamento. Os módulos durante a fase de "alívio" da tensão desviadora são praticamente coincidentes aos módulos durante as fases de recarga e carregamento.

Ao analisar os módulos resultantes do ensaio com nível de confinamento entre 500 e $750 \mathrm{kPa}$, verifica-se que a rigidez durante a fase inicial é em média 4,5 vezes menor que as demais fases. Durante a fase de alívio da tensão desviadora há uma ligeira queda dos valores dos módulos de deformabilidade, que inicialmente chegam a atingir $85 \mathrm{MPa}$.

Para maiores níveis de confinamento $\left(\sigma_{\mathrm{c}}>1000 \mathrm{kPa}\right)$, a rigidez é constante durante todo o processo de carregamento. Os módulos durante a fase inicial são em média 7 vezes menores que as fases de carregamento. 
Em geral, pode-se considerar que as fases iniciais, que procuram reproduzir os carregamentos construtivos de uma BEFC, dão origens a módulos de deformabilidade menores em relação às fases de carregamento, que por sua vez reproduzem as inversões das tensões principais maiores, semelhante ao que ocorre durante o carregamento hidrostático de uma BEFC.

As simulações de laboratório não identificaram qualquer distinção representativa entre os módulos de deformabilidade obtidos para a fase de "alívio" e "recarga" da tensão desviadora durante o processo de confinamento. O material granular ensaiado apresenta um comportamento de tensão-deformação praticamente linear quando submetido ao aumento do estado de tensão, mesmo sob condições de carregamento distintas em diferentes planos de atuação. 


\section{CONSIDERAÇÕES FINAIS}

\subsection{Conclusão}

- As análises do comportamento de deformação de estruturas de enrocamento são complexas, pois dependem de vários fatores que interferem nas propriedades mecânicas do material (litologia, tamanho e forma dos grãos, distribuição granulométrica, densidade relativa, estado de anisotropia, presença de água e fluência, estado e trajetória de tensões, entre outros). As leis constitutivas são pouco realistas e os modelos numéricos estão aquém da representatividade de campo, no que diz respeito às fases de carregamento para as diferentes regiões do maciço de BEFC. Dessa forma, é importante que se investigue sobre as propriedades dos materiais envolvidos nesse tipo de estrutura, juntamente com a observação de comportamento e o conhecimento empírico com referência aos incidentes históricos, para que as análises e previsões possam ser mais "satisfatórias".

- As tensões desenvolvidas no interior do maciço de BEFC se distinguem para as diferentes regiões do maciço durante as fases de carregamento próprio e hidrostático. As zonas do primeiro terço de montante sofrem com o fenômeno de inversão de tensões principais maiores e menores durante a fase de carregamento hidrostático, resultando em um processo chamado de "alívio" e "recarga" da tensão desviadora, sempre acompanhado de um aumento do estado de tensão (tensão octaédrica). As regiões próximas à face de montante são as mais sensíveis ao carregamento hidrostático, pois as tensões construtivas são relativamente baixas. Na região central do maciço, as tensões geradas na fase de construção são elevadas, pouco sendo influenciadas pelas cargas provenientes do enchimento do reservatório.

- A rocha de basalto que deu origem ao material granular dos ensaios laboratoriais era de excelente qualidade geomecânica, confirmado pelo seu alto valor de resistência à compressão simples e baixa absorção. Os fragmentos de rocha oriundos do processo 
de britagem se apresentaram bastante lamelares, com baixos valores de coeficientes de forma. A granulometria do material de ensaio foi determinada hipoteticamente e resultou em um coeficiente de uniformidade de aproximadamente 6,6. A densidade relativa dos ensaios foi estipulada em $80 \%$, valor estimado nas densidades que são atingidas em campo para o material de montante.

- Os ensaios de cisalhamento mostraram que as deformações específicas são típicas de materiais granulares compactos, apresentando dilatância na ruptura. Observou-se que a envoltória de resistência realmente se aproxima de uma hipérbole, resultando em um decréscimo do ângulo de atrito interno com o aumento do confinamento.

- Os cinco primeiros ensaios foram inicialmente programados visando determinar parâmetros que pudessem alimentar modelos de elasticidade variável como, por exemplo, o modelo hiperbólico. No entanto, os resultados dos ensaios de carregamento, chamados de convencionais, realizados com diferentes tensões confinantes, mostraram que as curvas tensão-deformação se aproximam da linearidade, tornando-se inadequado à interpretação de parâmetros através do modelo hiperbólico. Ao analisar os módulos secantes para esses ensaios, observou-se um pequeno decréscimo de rigidez no início do carregamento, permanecendo praticamente constante até a ruptura. Foi possível notar, também, que o aumento do estado de confinamento nos diferentes ensaios causa um enrijecimento das amostras para as correspondentes tensões desviadoras mobilizadas, valor este que atingiu até $90 \%$ quando as tensões confinantes foram aumentadas de 100 para $1000 \mathrm{kPa}$.

- Os ensaios triaxiais de carregamento com ciclos de descarga mostraram, como esperado, que os módulos de descarga-recarga são superiores aos módulos de carregamento entre 3 e 5 vezes. O material granular apresentou características clássicas de material plástico para o descarregamento, apresentando deformações específicas muito pequenas de recuperação. 
- O resultado do ensaio isotrópico evidenciou o ganho de rigidez do material com a aumento da tensão octaédrica.

- Os chamados ensaios "transversais", teoricamente, tentaram simular as trajetórias de tensões que se desenvolvem no interior do maciço de BEFC próximo ao espaldar de montante, durante as fases de construção e enchimento do reservatório. Os resultados mostraram que há uma diferença significativa entre os módulos obtidos na fase inicial e no restante do carregamento, ou seja, confirma-se a adoção de maiores valores de módulos de deformabilidade para as fases de carregamento hidrostático em relação a fase de carregamento próprio. Por meio dos ensaios, foi possível observar que essa relação entre módulos é tanto maior quanto maior o nível de confinamento. Dessa forma, é aceitável considerar menores valores de módulos de enchimento $E_{\text {ench }}$ para as regiões do maciço submetidas a menores confinamentos, como por exemplo, a região superior, na qual podem ocorrer maiores deflexões da face próximas à crista, como geralmente ocorre nas BEFC.

- O fenômeno de inversão de tensões principais maiores e menores foi simulado nos ensaios chamados "transversais" e mostraram claramente que não há variação de rigidez significante durante as fases de "alívio", "recarga" e "carregamento" da tensão desviadora, acompanhada do aumento do estado de tensões. Portanto, não é aceitável considerar diferentes módulos de rigidez em regiões do maciço onde supostamente se observam "alivio" e "recarga" das tensões cisalhantes.

\subsection{Sugestões para futuros trabalhos}

- Retroanálises utilizando dados de campo e informações de ensaios de laboratório no que diz respeito ao tipo de carregamento, estado de tensões, compacidade e granulometria de materiais granulares, visando refinar as análises numéricas para a obter previsões mais realistas. 
- Estudar o fenômeno de fluência (creep) dos materiais de enrocamento sob condições de diferentes velocidades de carregamento e de presença de água.

- Estudo específico de engenharia estrutural da face de concreto e da interface entre a laje e o material granular compacto. 


\section{REFERÊNCIAS}

BASSO, R. V.; CRUZ, P. T. Estudo de deformabilidade de enrocamentos visando BEFC. In: CONGRESSO BRASILEIRO DE MECÂNICA DOS SOLOS E ENGENHARIA GEOTÉCNICA, 13., 2006, Curitiba, PR. Anais... Curitiba, PR: ABMS, 2006. p. 1971-1976.

BECKER, E.; CHAN, C.; SEED, B. Strength and deformation characteristics of rockfill materials in plane strain and triaxial compression tests. California: Department of Civil Engineering, University of California, 1972. p. 1-121. (Report TE-72-3).

BOUGHTON, N. O. Elastic analysis for behaviour of rockfill. Journal of the Soil Mechanics and Foundations Division, New York, v. 96, n. SM5, p. 1715-1734, 1970.

COOKE, J. B. The development of today's CFRD dam. In: SIMPÓSIO SOBRE BARRAGENS DE ENRONCAMENTO COM FACE DE CONCRETO, 2., 1999. Anais... Florianópolis, SC, 1999. p. 1-10.

.; SHERARD, J. L. Concrete-face rockfill dams: design, construction and performance. In: AMERICAN SOCIETY OF CIVIL ENGINEERS. GEOTECHNICAL ENGINEERING DIVISION. ASCE NATIONAL CONVENTION, 1985, Detroit, Mich. Proceedings... Detroit, USA, 1985. p. 658.

COVARRUBIAS, S. W. Cracking of earth and rockfill dams. 1969. 22 f. Tese (Ph. D.) Harvard University, Cambridge, Mass., USA, 1969.

CRUZ, P. T. 100 barragens brasileiras: casos históricos, materiais de construção, projeto. São Paulo: Oficina de Texto, 1996. 648 p.

Barragem de enrocamento com face de concreto: ainda algumas considerações.

SEMINÁRIO NACIONAL DE GRANDES BARRAGENS, 26., Goiânia, GO. Anais... Goiânia, GO: CBB, 2005.

Projeto e desempenho de maciços de enroncamento: comentários da mesa de encerramento. In: SIMPÓSIO SOBRE BARRAGENS DE ENRONCAMENTO COM FACE DE CONCRETO, 2., 1999, Florianópolis, SC. Anais... Florianópolis, SC, 1999. 
DE MELLO, V. F. B. Reflections on design decisions of practical significance to embankment dams. Géotechnique, v. 27, n. 3, p. 279-355, 1977.

DUNCAN, J. M.; CHANG, C. Y. Nonlinear analysis of stress and strain in soils. Journal of the Soil Mechanics and Foundations Division, New York, v. 96, p.1629-1653, 1970.

FUMAGALLI, E. Compressibility and triaxial tests on granular rock material with no pore pressure. In: ICSMFE, 7., Mexico, D.F. Proceedings... Mexico, D.F., 1969. p. 51-60.

GAIOTO, N. A evolução das barragens de enroncamento com face de concreto. São Paulo: EESC/USP, 1997.

GEO-SLOPE INTERNATIONAL LTD. SIGMA/W for finite element stress and deformation analysis: user's guide version 5. Calgary, Alberta, Canadá, 2002.

GOULART, M. L. S. Retroanálise da laje da barragem de enrocamento com face de concreto da UHE Machadinho. 2004. 84 f. Dissertação (Mestrado) - Escola Politécnica, Universidade de São Paulo, São Paulo, 2004.

HOLTZ, W. G.; GIBBS, H. J. Triaxial shear tests on pervious gravelly soils. In: INTERNATIONAL CONFERENCE ON SOIL MECHANICS AND FOUNDATION ENGINEERING, 4., 1957, London. Proceedings... London: Butterworths Scientific, 1957. v. 2.

HORN, H. M.; DEERE, D. U. Frictional characteristics of minerals. Géotechnique, London, v. 7, 1962.

JANBU, N. Soil compressibility as determined by oedometer and triaxial test. In: EUROPEAN CONFERENCE ON SOIL MECHANICS AND FOUNDATION ENGINEERING, 4., 1963, Wiesbaden. Proceedings... Wiesbaden, 1963. v. 1, p. 19-26.

KONDNER, R. L. Hyperbolic stress-strain response: cohesionless soils. Journal of the Soil Mechanics and Foundations Division, New York, n. SM1, p. 115-143, 1963.

LAMBE, T. W.; WHITMAN, R. V. Soil mechanics. New York: Wiley, 1969. ix, 553 p. 
MARACHI, D. et al. Strength and deformation characteristics of rockfill material. California: University of California, Department of Civil Engineering, 1969. 139 p. (Report $N^{\circ}$ TE-69-5).

MARQUES FILHO, P.; PINTO, N. L. S. CFRD DAM characteristics learned from experience. International Water Power \& Dam Construction, London, n. 1, 2005.

MARSAL, R. J. Mechanical properties of rockfill. In: HIRSCHFELD, R. C.; POULOS, S. J. Embankment dam engineering: Casagrande volume. New York: J. Wiley, 1973. p. 109-200.

. Particle breakage in coarse granular soils. In: INTERNATIONAL CONFERENCE ON SOIL MECHANICS AND FOUNDATION ENGINEERING, 7., 1969, Mexico, D.F. Proceedings... Mexico, D.F., 1969. Specialty Session, n .13, p. 1-79.

Strain computation in earth-rockfill dams. In: INTERNATIONAL CONFERENCE ON SOIL MECHANICS AND FOUNDATION ENGINEERING, 9., 1977, Tokio. Proceedings... Tokio, 1977. Specialty Session, n. 8, p. 1-2.

MARULANDA, A.; PINTO, N. L. S. Recent experience on design, construction and performance of CFRD dams In: COOKE, J. B. Concrete face rockfill dams. Beijing, 2000. p. 279-315.

MATERON, B. Compressibilidade e comportamento de enrocamentos. In: SIMPÓSIO SOBRE A GEOTECNIA DA BACIA DO ALTO PARANÁ, 1983, São Paulo. Anais... São Paulo: Abge/Abms, 1983.

.; MORI R. T. Construction features of CFRD Dams. In: COOKE, J. B. Concrete face rockfill dams. Beijing, China: [s.n.], 2000. p. 177-219.

MORI, R. T. Deformações e trincas em barragens de enrocamento com face de concreto. In: SIMPÓSIO SOBRE BARRAGEM DE ENROCAMENTO COM FACE DE CONCRETO, 2. 1999, Florianópolis, SC. Anais... Florianópolis, SC: CBDB, 1999. p. 47-60.

.; SOBRINHO, J. A. Aplicação de um novo veda-juntas nas lajes da barragem de enrroncamento com face de concreto de Ita. In: SIMPÓSIO SOBRE BARRAGEM DE ENROCAMENTO COM FACE DE CONCRETO, 3., 1999, Florianópolis, SC. Anais... Florianópolis, SC: CBDB, 1999. 
NEVES, E. M. Algumas considerações sobre a mecânica do enrocamento. Solos e Rochas: revista latino-americana de geotecnia, Rio de Janeiro, v. 25, n. 3, p.161-203, 2002.

.; VEIGA PINTO, A. A. Enrocamentos: actualização de conhecimentos, estudos experimentais e aplicações em barragens e vias de comunicação. Lisboa: LNEC, 1977.

NOBARI, E.; DUNCAN, J. Effect on reservoir filling on stresses and movements in earth and rockfill dams. California: Department of Civil Engineering, University of California, 1972. 186 p. (Report No TE-72-1).

OLDECOP, L. A.; ALONSO, E. E. A model for rockfill compressibility. Géotechnique, London, v. 51, n. 2, p. 127-139, 2001.

OLIVEIRA, L. O. C. A importância do zoneamento no comportamento de barragens de enroncamento com face de concreto. 2005. 172 f. Dissertação (Mestrado) - Escola Politécnica, Universidade de São Paulo, São Paulo, 2005.

PENMAN, A. D. M. Material and construction methods for embankment dams and cofferdams. In: INTERNATIONAL COMMISSION ON LARGE DAMS, 14., 1982, Rio de Janeiro. Proceedings... Rio de Janeiro, 1982. v. 5, p. 526-541.

Rockfill for embankment dams. In: MARSAL, R. J. Mexican society for soils mechanics. México, 1992. p. 303-327.

.; ROCHA FILHO, P. Instrumentation for CFRD dams. In: COOKE, J. B. Concrete face rockfill dams. Beijing, China: [s.n.], 2001. p. 221-277.

PINTO, N. L. S.; MARQUES, P. L. Estimating the maximum face deflection in CFRDs. The International Journal on Hydropower \& Dams, v. 5, n. 6, 1998.

SABOYA JR., F. Análise do comportamento de barragens de enroncamento com face de concreto durante o período de construção e enchimento. 1993. $261 \mathrm{f}$. Tese (Doutorado) Pontifícia Universidade Católica do Rio de Janeiro, Rio de Janeiro, 1993.

SANTOS, A.C.C.; FLEURY, S. V.; ASSIS, A. P. Estudo de laboratório da deformabilidade de enrocamentos considerando o efeito de escala. In: SEMINÁRIO NACIONAL DE GRANDES BARRAGENS, 26., 2005, Goiânia, GO. Anais... Goiânia, GO: CBB, 2005. 
SOBRINHO, J. A. et al. Development aspects of CFRD in Brazil. In: COOKE, J. B. Concrete face rockfill dam. Beijing, China: [s.n.], 2000. p. 153-175.

TERZAGHI, K.; PECK, R. B. Soil mechanics in engineering practice. New York: J. Wiley, 1948. xviii, 566 p.

VEIGA PINTO, A. A. Características de resistência e deformabilidade de materiais de enrocamento. Geotecnia, Lisboa, n. 27, p. 3-41, 1979.

Modelação de enrocamentos. 1992. 76 f. Dissertação (Mestrado) - Universidade Nova de Lisboa, Portugal, 1982.

Previsão do comportamento estrutural de barragens de enrocamento. $1983.157 \mathrm{f}$. Tese (Doutorado) - Laboratório Nacional de Engenharia Civil, Lisboa, Portugal, 1983.

ZELLER, J.; WULLIMANN, R. The shear strength of the shell materials for the goschenenalp dam, Switzerland. In: INTERNATINAL CONFERENCE, SOIL MECHANICS AND FOUDATION ENGINEERING, 6., 1957, Switzerland. Proceedings... Switzerland, 1957. v. 2, p. 399-404. 


\section{Apêndice A: Modelo Hiperbólico}

Kondner et al. (1963), mostraram que as curvas de elasticidade variável podem ser ajustadas aproximadamente a hipérboles (Equação 24).

$$
\frac{\varepsilon_{1}}{\left(\sigma_{1}-\sigma_{3}\right)}=a+b \varepsilon_{1}
$$

Cuja forma geométrica pode ser graficamente representada na Figura 58.

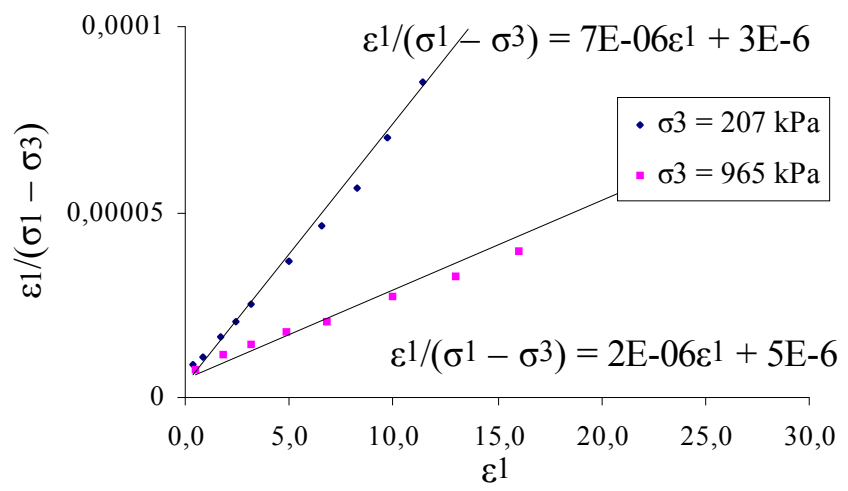

Figura 58. Trasformada da curva tensão-deformação de ensaio triaxial ( $\varnothing=12$ ") para o enroncamento do basalto São Francisco, Marachi (1969).

Verifica-se que $a$ é igual ao inverso do módulo de Young tangente na origem da curva tensãodeformação $\left(E_{i}\right)$ e $b$ é o inverso da assíntona da hipérbole, cujo valor é igual a $\left(\sigma_{1}-\sigma_{3}\right)_{\mathrm{U}} \mathrm{e}$ portanto sempre superior ao valor máximo de resistência ao corte $\left(\sigma_{1}-\sigma_{3}\right)_{R}$.

Muitas vezes os valores se afastam do traçado gráfico linear e que o melhor ajustamento da curva é obtida considerando os pontos correspondentes a 70 e $95 \%$ da resistência de corte mobilizada, Duncan \& Chang (1970). 
Geralmente a rigidez inicial $E_{i}$ é variada dependendo do nível de tensão confinante $\sigma_{3}$, portanto Janbu (1963) sugeriu a Equação 25.

$$
E_{i}=K p_{a}\left(\frac{\sigma_{3}}{p_{a}}\right)^{n}
$$

Da representação gráfica, em escala logarítmica é possível obter os valores de $k$ e $n$.

A variação de $\left(\sigma_{1}-\sigma_{3}\right)_{\mathrm{U}} \operatorname{com} \sigma_{3}$ é tomada em conta a partir das relações entre a resistência ao corte na ruptura $\left(\sigma_{1}-\sigma_{3}\right)_{\mathrm{R}} \operatorname{com}\left(\sigma_{1}-\sigma_{3}\right)_{\mathrm{U}}$, para cada $\sigma_{3}$. Assim, a Equação 26 define o coeficiente de ruptura $R_{f}$.

$$
R_{f}=\frac{\left(\sigma_{1}-\sigma_{3}\right)_{R}}{\left(\sigma_{1}-\sigma_{3}\right)_{U}}
$$

Normalmente o valor de $R_{f}$ varia de 0.5 a 0.9 .

O valor de $\left(\sigma_{1}-\sigma_{3}\right)_{\mathrm{R}}$ pode ser obtido a partir do critério de ruptura de Mohr-Coulomb, da seguinte forma (Equação 27):

$$
\left(\sigma_{1}-\sigma_{3}\right)_{R}=\frac{2 c \cos \varphi+2 \sigma_{3} \operatorname{sen} \varphi}{1-\operatorname{sen} \varphi}
$$

em que $c$ e $\varphi$ são coesão e angulo de atrito interno do material.

Assim, pelo ajuste à curva de envoltória de resistência passando pela origem, tem-se a Equação 28:

$$
\varphi=\operatorname{sen}^{-1}\left(\frac{\left(\sigma_{1}-\sigma_{3}\right)_{R}}{\left(\sigma_{1}+\sigma_{3}\right)_{R}}\right)
$$


Para enroncamentos, existe uma certa variação do ângulo de atrito interno com o aumento da tensão confinante, assim tomar um único valor de $\varphi$ para o material pode ser incorreto. Tem-se verificado que o valor de $\varphi$ diminui com o aumento da tensão de confinamento como mostra na Figura 59.

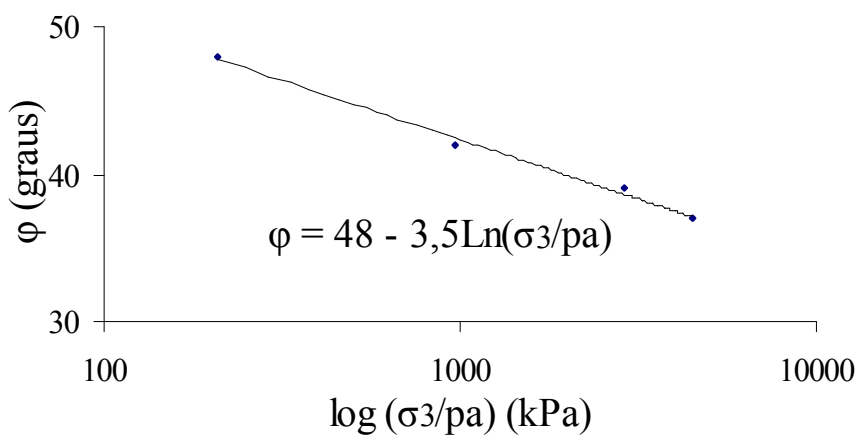

Figura 59. Variação do ângulo de atrito interno com a tensão confinante para o enroncamento do basalto de São Francisco, Marachi (1969).

Pode-se considerar, neste caso, uma expressão do tipo (Equação 29):

$$
\varphi=\varphi_{0}-\Delta \varphi \log \left(\frac{\sigma_{3}}{p_{a}}\right)
$$

Quando há um alivio na tensão cisalhante no ensaio triaxial, verifica-se que somente uma pequena parcela das deformações processadas anteriormente na fase de carregamento são recuperáveis, exibindo, portanto um comportamento não elástico (Figura 60). 


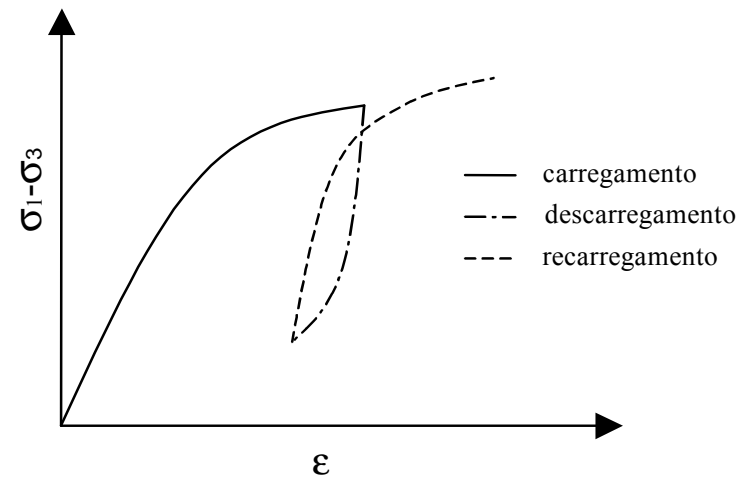

Figura 60. Gráfico de descarga e recarga da tensão desviadora.

No modelo hiperbólico é usual considerar o módulo de elasticidade descarga-recarga através da Equação 30:

$$
E_{D R}=K_{D R} p_{a}\left(\frac{\sigma_{3}}{p_{a}}\right)^{n}
$$

O módulo de elasticidade tangente $E_{t}$, em cada ponto da curva tensão deformação, pode ser obtido por diferenciação da Equação A.1 em relação a $\varepsilon$ e toma a seguinte forma (Equação 31):

$$
E_{t}=\left[1-\frac{R_{f}(1-\operatorname{sen} \varphi)\left(\sigma_{1}-\sigma_{3}\right)}{2 c \cos \varphi+2 \sigma_{3} \operatorname{sen} \varphi}\right]^{2} K p_{a}\left(\frac{\sigma_{3}}{p_{a}}\right)^{n}
$$

O coeficiente de Poisson é calculado através do módulo de deformação volumétrico $B_{m}$ que é representado pelas Equações 32 e 33.

$$
\begin{gathered}
B_{m}=\frac{\Delta \sigma_{1}+\Delta \sigma_{2}+\Delta \sigma_{3}}{\Delta \varepsilon_{v}} \\
B_{m}=\frac{E}{3(1-2 v)}
\end{gathered}
$$


Como o módulo de deformação volumétrico é variável com a tensão confinante, então os parâmetros $K_{b}$ e $m$ da Equação 34, também serão necessários para dar entrada no modelo.

$$
B_{m}=K_{b} p_{a}\left(\frac{\sigma_{3}}{p_{a}}\right)^{m}
$$

Assim, resume-se que são necessários ensaios triaxiais para a determinação dos parâmetros. Ensaios convencionais de carregamento com diferentes tensões confinantes fornecem os parâmetros $k, n$ e $\varphi$ necessários para obter-se $E_{i}, E_{t}$ e $R_{f}$. Ensaios contendo carregamento, descarregamento e recarregamento da tensão desviadora, também com diferentes níveis de confinamento, são necessários para a obtenção dos parâmetros $k_{D R}$ e $n$ da Equação A.7. Para finalizar, é necessário que se realize um ensaio do tipo carregamento isotrópico para obtenção de $k b$ e $m$. 